\title{
Lignocellulosic Feedstock Resource Assessment
}

T. Rooney

NEOS Corporation

Lakewood, Colorado

Technical Monitor: A.E. Wiselogel

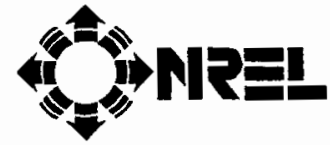

National Renewable Energy Laboratory 1617 Cole Boulevard

Golden, Colorado 80401-3393

A national laboratory of the U.S. Department of Energy Operated by Midwest Research Institute for the U.S. Department of Energy Under Contract No. DE-AC36-83CH10093

Prepared under Subcontract Number ACG-7-17032-01

September 1998 
This publication was reproduced from the best available camera-ready copy submitted by the subcontractor and received no editorial review at NREL.

\section{NOTICE}

This report was prepared as an account of work sponsored by an agency of the United States government. Neither the United States government nor any agency thereof, nor any of their employees, makes any warranty, express or implied, or assumes any legal liability or responsibility for the accuracy, completeness, or usefulness of any information, apparatus, product, or process disclosed, or represents that its use would not infringe privately owned rights. Reference herein to any specific commercial product, process, or service by trade name, trademark, manufacturer, or otherwise does not necessarily constitute or imply its endorsement, recommendation, or favoring by the United States govemment or any agency thereof. The views and opinions of authors expressed herein do not necessarily state or reflect those of the United States government or any agency thereof.

Available to DOE and DOE contractors froin:

Office of Scientific and Technical Information (OSTI)

P.O. Box 62

Oak Ridge, TN 37831

Prices available by calling (423) $576-8401$

Available to the public from:

National Technical Information Service (NTIS)

U.S. Department of Commerce

5285 Port Royal Road

Springfield, VA 22161

(703) $487-4650$ 


\section{Foreword}

This report serves several purposes. First, it provides overall state and national information on the quantity, availability, and costs of current and potential feedstocks for ethanol production in the United States. It characterizes end uses and physical characteristics of feedstocks, and presents relevant information that affects the economic and technical feasibility of ethanol production from these feedstocks. The data can help researchers focus ethanol conversion research efforts on feedstocks that are compatible with the resource base.

The information presented in this study reflects current dataand estimates. Residues examined include agricultural, forest products industry, and urban tree residues (UTR). State-level maps show quantity and availability for the conterminous United States. State-level price information is provided when available or for spot market prices for commodities for which price data are limited. For agricultural crop residues markets are not common, so prices represent costs of collection plus allowances for economic profits. The geographic scale of economic and resource data makes independent estimates of cost and quantity necessary for individual business proposals.

This document is intended for distribution to U.S. Department of Energy (DOE) National Renewable Energy Laboratory (NREL) decision makers with a stake in promoting the successful introduction of renewable fuel technologies. Creative uses of residuals from agricultural and forestry enterprises can have rural economic development benefits and sustain communities. 


\section{Preface}

This study was commissioned and funded by DOE/NREL. Federal and private organizations that provided information essential to the project include the U.S. Department of Agriculture (USDA) National Agricultural StatisticsService (NASS), the USDA Forest Service, the DOE Energy Information Administration (EIA), the U.S. Department of Commerce (DOC), the Corn Refiners Association (CRA), the Institute for Brewing Studies, Timber-Mart South, Timber-Mart North, the American Forest and Paper Association, the Lockwood Post Pulp and Paper Directory staff, the National Council for Air and Stream Improvement, and the Renewable Fuels Association.

The authors want to thank Dr. Art Wiselogel and William Case for their insights on and vision for the project, and for administering the subcontract agreement between NEOS Corporation and NREL.

The authors are grateful to individuals at Feedstuffs who provided price information for corn fiber. Dr. Paul Chandler contributed data that provided background into the competing uses for spent brewers grains. The staff at Franklin Associates and Biocycle provided information integral to the estimation of paper production and recovery on a state level. Dr. Ben Legendere of the Louisiana State University Cooperative Extension and Gene Young of the Tennessee Valley Authority provided useful contacts and information regarding the production and use of sugarcane bagasse throughout the United States. Phil Badger of DOE's Southeastern Regional Biomass Energy Program provided information and leads for forest products industry residues and sugarcane bagasse. Other contacts who provided direct and indirect support for this effort are too numerous to mention.

Finally, errors may remain in the text and data of this report despite all efforts to correct them. Please direct any questions to NEOS Corporation, 215 S. Union Blvd. Suite 610, Lakewood, CO 80228. NEOS Corporation staff who worked on this report include Scott Haase, Pat Saito, and Timothy Rooney. 


\section{Executive Summary}

DOE's Office of Fuels Development (OFD) and NREL's Biofuels Program are developing ethanol production technologies that use lignocellulosic resources as feedstocks for producing ethanol as a transportation fuel. NREL undertook this project in an effort to address a lack of basic resource information on many feedstocks. Public and private sector entities often approach BP and OFD with feedstock-driven opportunities. Although these niche opportunities could be important in commercialization efforts, the potential feedstock resources are must be large enough to warrant further investigations from BFP and OFD.

The objective of this resource assessment wasto describe the distribution, quantity, availability, competing uses, and current market value of select lignocellulosic feedstocks in the United States. It provided feedstock data at the state level for use as a macro-level screening tool. Local, site-specific market studies need to be conducted to make siting decisions for individual production facilities.

Thisstudy focused on agricultural crop residues, food processing by-products, forest products industry residues, and several post-consumer wastes. Agricultural crop residues included corn stover, hay-alfalfa, small grain straw (wheat, rye, barley, oats, and sorghum), and ricestraw. Food processing industry wastes included corn gluten meal (CGM) and corn gluten feed (CGF) from corn wet milling operations, distillers dried grains (DDG) from corn dry milling operations, sugarcane bagasse, and spent grain from beer brewing. Forestry and forest products industry coproducts were primary and secondary mill residues, recycled prinary paper pulp sludge, and UTR. Postconsumer feedstocks included recovered newsprint and mixed office paper. This assessment relied on data for feedstock quantity, availability, and price estimates. A detailed literature and World Wide Web search provided source data.

The USDA NASS provided state-level crop acreage and yield data for agricultural crop residues and sugarcane. Published information from NREL and other sources provided estimates of crop residue production per unit of crop yield, which allowed feedstock quantity estimates. Pricesforcrop residues were estimated based on collection costs with the addition of a retum for land, equipment, and soil nutrients. DOE and CRA provided data on corn milling establishments and employment, allowing the assembly of quantity, and availability maps of CGF, CGM, and DDG.

$\mathrm{DOE}$ and various state agencies provided input quantity and price data for primary and secondary forest products industry residues. The Lockwood Post Pulp and Paper Directory provided the means to estimate production of recycled paper pulp sludge. A national inventory provided UTR quantity data. Prices for paper sludge and UTR (or costs for landfilled quantities) were approximated by published landfill costs. Newsprint and mixed office paper quantities were estimated based on state-level municipal solid waste (MSW) figures and national average MSW recovery percentages. Published industry prices were used for recovered fiber prices.

Available quantity and price estimates for the United States as a whole are shown in Table ES-1 ranked by price (excluding transport costs). Several had negative prices (for feedstocks that are currently landfilled). Most had high use rates for value-added products such as pulp chips, animal feed, or fuel.

Significant negative prices for UTR and recycled primary paper pulp sludge make these feedstocks candidates for further research. The conditions that may allow commercial applications of ethanol conversion technology differ for the two feedstocks, however. In the case of UTR (a feedstock of heterogeneous quality available from many sources), the negative price of the feedstock may be offset by higher ethanol production costs and feedstock handling issues.

Recycled primary paper pulp sludge is likely to be easier to process and more homogeneous than UTR, and has lower transportation costs for on-site production facilities. Conversion efficiency and economies of scale are crucial in determining the viability of paper sludge-to-ethanol facilities. 
Table ES-1. Summary of 1996 available feedstock quantity and price (ranked by price)

\begin{tabular}{|c|c|c|c|}
\hline \multirow[b]{2}{*}{ Yeeristoglk } & \multicolumn{2}{|c|}{ Ourntity. } & 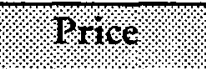 \\
\hline & $1000 \mathrm{~d}$ - 1 . & $8 \%$ of $1.0 \mathrm{tal}$ & $4 / \mathrm{dr} / 100$ \\
\hline Recycled primary paper pulp sludge & $3,358.1$ & $1.0 \%$ & $\$(32.21)$ \\
\hline UTR & $37,953.0$ & $11.3 \%$ & $\$(27.44)$ \\
\hline Mixed office paper & $4,857.0$ & $1.4 \%$ & $\$ 2.08$ \\
\hline Sugarcane bagasse & 708.6 & $0.2 \%$ & $\$ 5.84$ \\
\hline Newsprint & $11,232.0$ & $3.3 \%$ & $\$ 14.88$ \\
\hline Softwood secondary mill residue & 607.6 & $0.2 \%$ & $\$ 20.03$ \\
\hline Hardwood secondary mill residue & 440.9 & $0.1 \%$ & $\$ 20.10$ \\
\hline Hardwood primary mill residue & 978.5 & $0.3 \%$ & $\$ 22.32$ \\
\hline Softwood primary mill residue & $1,255.4$ & $0.4 \%$ & $\$ 22.75$ \\
\hline Corn stover & $233,614.9$ & 69.6 & $\$ 25.26$ \\
\hline Rice & $2,666.1$ & $0.8 \%$ & $\$ 23.80$ \\
\hline Hay-alfalfa & $28,567.8$ & $8.5 \%$ & $\$ 65.21$ \\
\hline CGF & $5,664.5$ & $1.7 \%$ & $\$ 95.23$ \\
\hline Spent brewers grains & $1,064.4$ & $0.3 \%$ & $\$ 130.84$ \\
\hline DDG & $1,797.9$ & $0.5 \%$ & $\$ 131.93$ \\
\hline CGM & $1,119.8$ & $0.3 \%$ & $\$ 206.98$ \\
\hline Small grain straw & 0 & $0.0 \%$ & $\mathrm{n} / \mathrm{a}$ \\
\hline Total/Average & $335,886.5$ & $100.0 \%$ & $\$ 44.49$ \\
\hline
\end{tabular}

Mixed office paper, sugarcane bagasse, and corn stover (listed in order of increasing cost) will be available at positive prices, but are low enough in value to warrant attention as viable candidates for ethanol production technologies. Regional mixed office paper price variability will substantially affect its viability as a feedstock in some locations. Although national average prices are positive, spot prices in the Northeast are negative, meaning that the Northeast may present opportunities for office paper to be used as an ethanol feedstock. Sugarcane bagasse is also low cost, although most (80\%) is currently used (bagasse data in Table ES-1 indicate unused quantities). The efficiency of individual bagasse conversion facilities may also affect bagasse viability. More bagasse may be available given the marginal value of sugarcane bagasse used in some low-efficiency electricity and heat generation applications. Sugarcane bagasse and rice straw are currently commercial feedstocks for ethanol production. Wastepaper has been investigated as an ethanol feedstock since the mid-1990s in the Northeast. Corn stover is by far the single largest potential feedstock, although its actual value is subject to some question because of the variation in estimates of the value of corn stover for fertilizer, forage, and soil conservation. Regional and local soil conditions and nutrient cost variability may affect corn stover price and availability to a greater degree than indicated in this effort. 
Newsprint and mill residues have intermediate value and are mostly collected and used. However, the size of these resources still leaves a large amount potentially available for ethanol production. Newsprint follows similar geographic trends as mixed office paper; the northeastern United States is a key area for further examination. Primary mill residues are mostly used by the producers or sold to pulp and paper producers. The high value of coarse mill residues makes their role in future ethanol production efforts unlikely. Fine primary residues are less costly. Secondary mill residues are often unused and less costly primary residues.

Feedstocks such as brewers grains, DDG, com fiber, and hay-alfalfa straw have high value as ruminant and poultry feeds, and are not likely to be economically viable stand-alone ethanol feedstocks given current transportation fuel prices.

Many data availability issues affected the accuracy and usability of the data used to derive residue estimates. Statelevel data on competing uses for agricultural residues used in forage or other competing uses may be more meaningful for potential ethanol producers than estimates of availability based on soil conservation requirements. Information on the willingness of farmers to shift from forage practices to residue collection and sale could provide a basis for estimating agricultural residues consumed in "non-captive" uses.

Secondary mill residue data should be expanded to include regional variation in residue production coefficients that are currently being developed in several areas of the United States. Also, estimates should be performed for individual Standard Industrial Code (SIC) classes when SIC-specific residue coefficients are compiled by Pennsylvania State University and the Tennessee Valley Authority (TVA). If paper recovery data were available on a state (or at least a regional) level, state newsprint and office paper estimates would be more reliable. Further research into the feasibility of conversion of mixed foliage and wood into ethanol will provide more useful information as to the viability of UTR.

The usefulness of the data presented in this report will be enhanced if the results are published on the World Wide Web. Its flexibility and wide audience will generate more interest in the use of these underused resources and could provide the basis for future partnership opportunities between commercial enterprises and federal and state energy agencies. These cooperative chances spur technological adaptation and can modify long-run industrial energy production and consumption.

Next steps in characterizing these feedstocks should include updating data with new sources that are becoming available in 1998. Among these are USDA Forest Service primary mill residue production data, TVA secondary mill residue data, USDA Forest Service updated primary and secondary mill databases, and Pennsylvania State University secondary mill residue and industry data. Additional feedstocks to add to the report include cotton gin trash, for which data will soon be available for most of the southeastern United States, and can be modified for other cotton-producing states. 


\section{Contents}

Foreword i

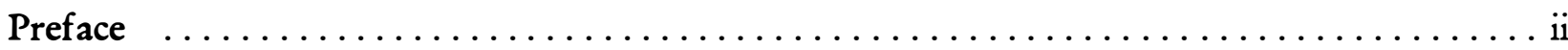

Executive Summary $\ldots \ldots \ldots \ldots \ldots \ldots \ldots \ldots \ldots \ldots \ldots \ldots \ldots \ldots \ldots \ldots \ldots \ldots \ldots \ldots$

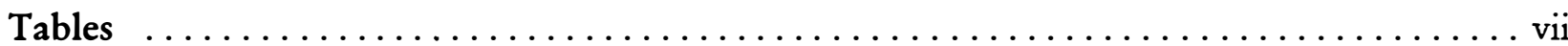

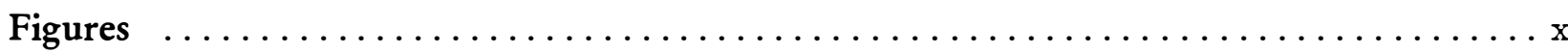

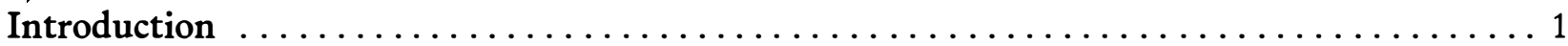

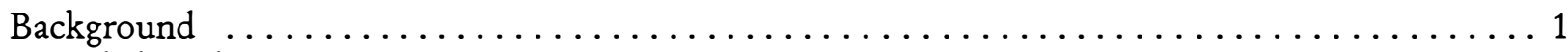

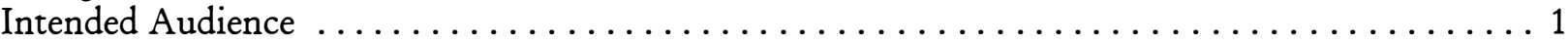

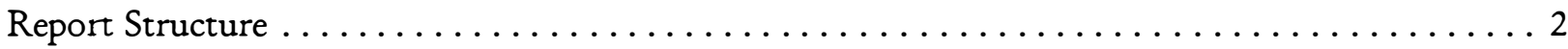

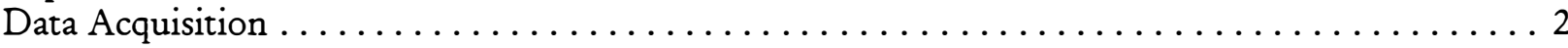

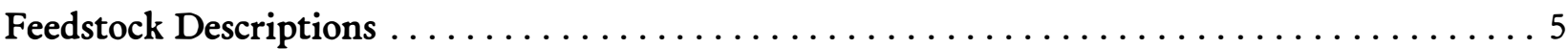

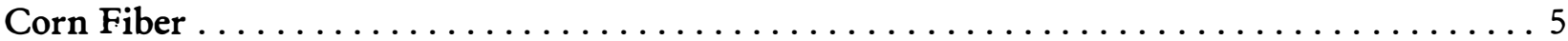

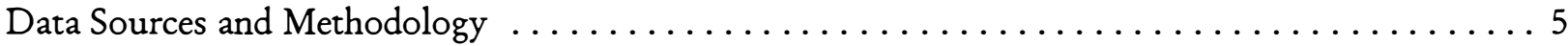

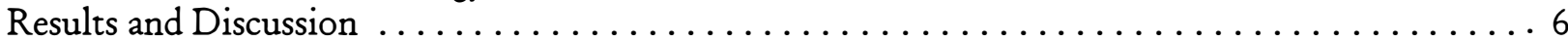

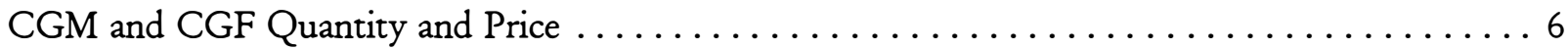

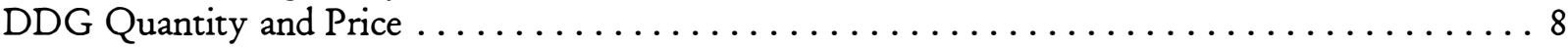

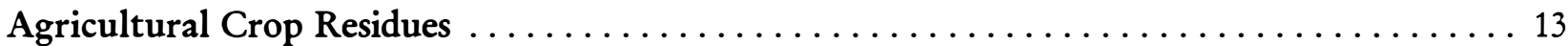

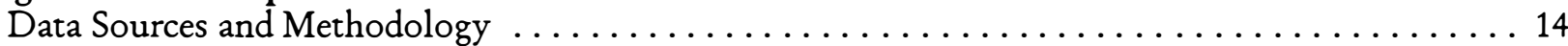

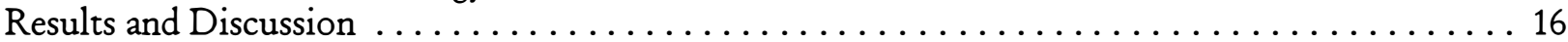

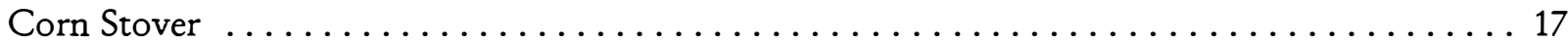

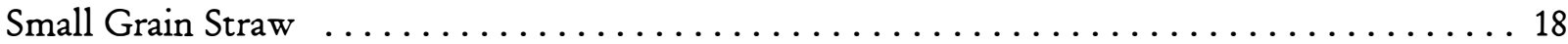

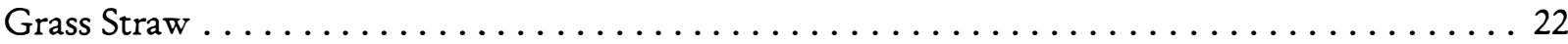

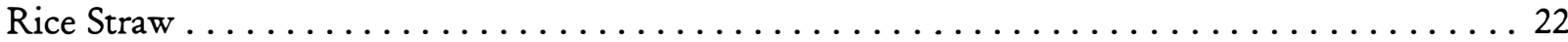

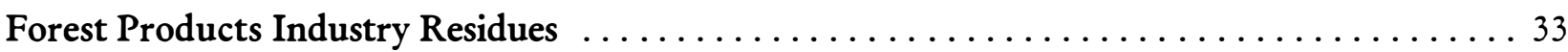

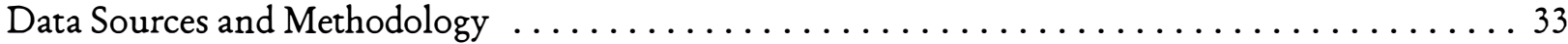

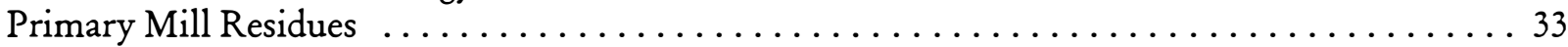

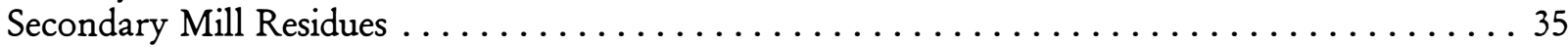

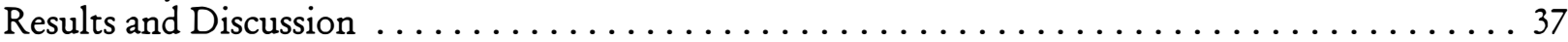

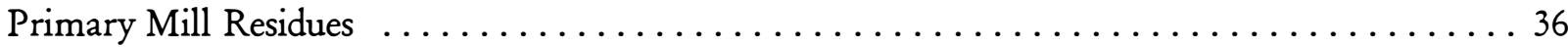

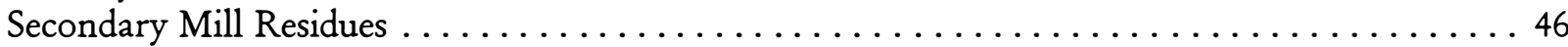

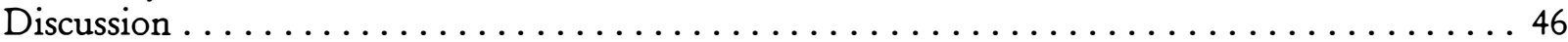

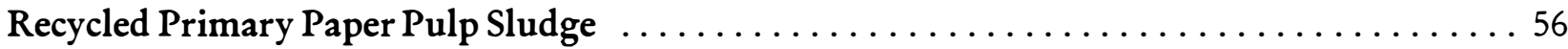

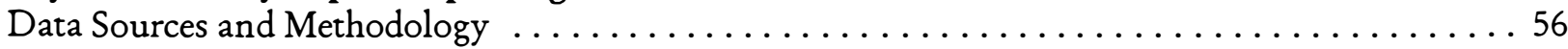

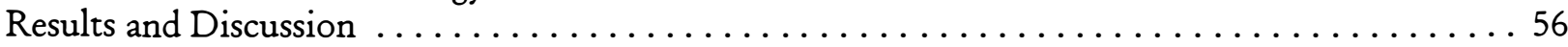

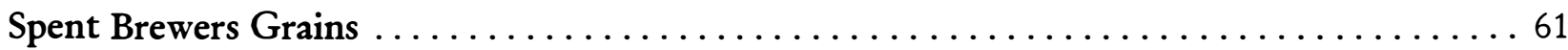

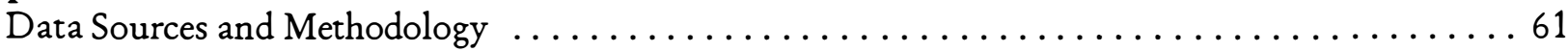

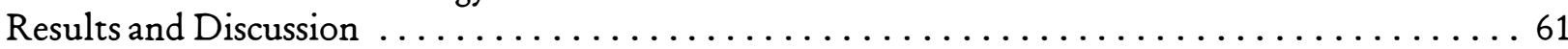




\section{Contents (con't)}

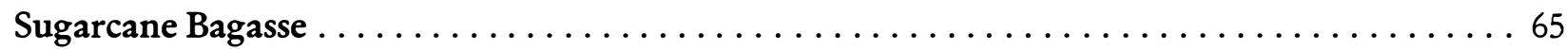

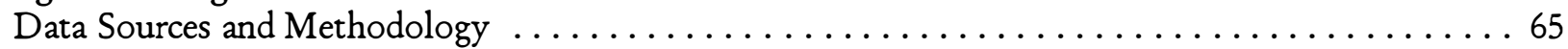

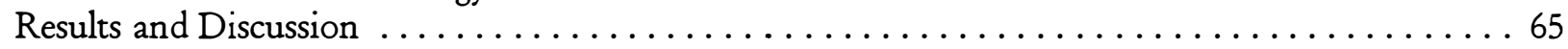

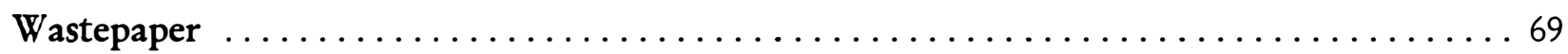

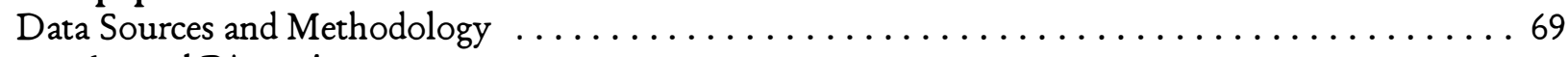

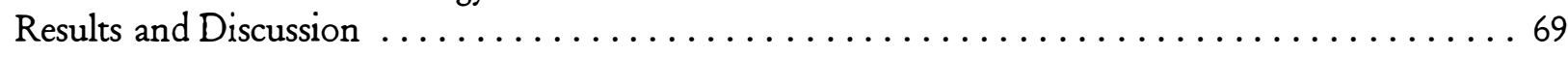

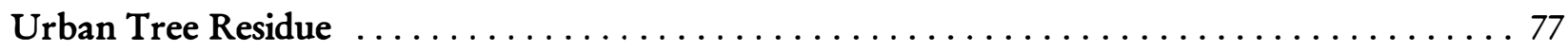

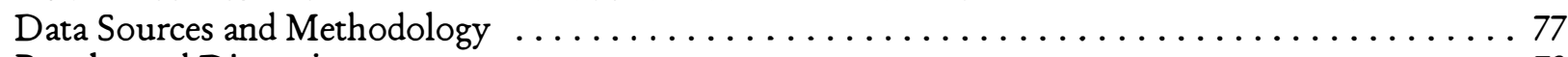

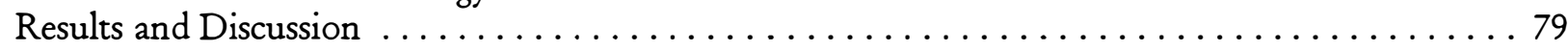

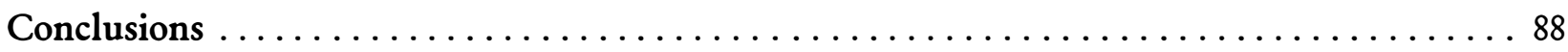

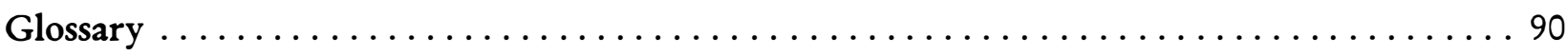

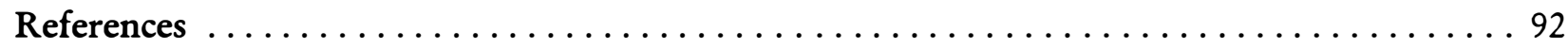

Appendixes

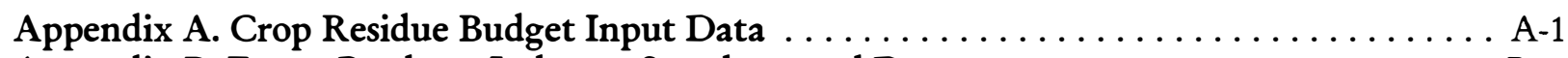

Appendix B. Forest Products Industry Supplemental Data $\ldots \ldots \ldots \ldots \ldots \ldots \ldots \ldots \ldots$ B-1

Appendix C. Brewers Spent Grain Supplemental Data . . . . . . . . . . . . . C-1 


\section{Tables}

Page

Table ES-1. Summary of 1996 available feedstock quantity and price $\ldots \ldots \ldots \ldots \ldots \ldots$ iv

Table 1. Typical energy content (Btu/lb) moisture content percent for lignocellulosic feedstocks . . 4

Table 2. 1996 wet corn mill count by state, mill employee size class, estimated total state employment, and CGF/CGM production . . . . . . . . . . . . . . . .

Table 3. Average $1995 / 1996$ CGM and CGF prices $(\$ /$ dry ton $) \ldots \ldots \ldots \ldots \ldots \ldots \ldots$

Table 4. 1996 dry mill ethanol capacity (1,000,000 gallons/year) and estimated DDG production

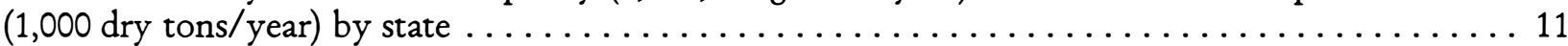

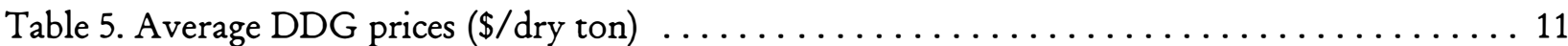

Table 6. Technically and economically viable residue yields, and residue per unit crop yield . . . . 14

Table 7.1996 crop residue nutrient values $(\$ /$ dry ton of residue $) \ldots \ldots \ldots \ldots \ldots \ldots \ldots \ldots \ldots$

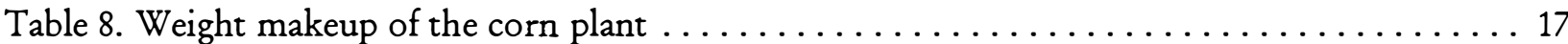

Table 9.1996 corn stover quantity, availability, and price estimates $\ldots \ldots \ldots \ldots \ldots \ldots \ldots$

Table 10. Quantity and percent of total small grain production by crop component $\ldots \ldots \ldots 22$

Table 11. 1996 small grain straw quantity, availability, and price estimates $\ldots \ldots \ldots \ldots \ldots 24$

Table 12. Hay-alfalfa straw quantity, availability, and price estimates $\ldots \ldots \ldots \ldots \ldots \ldots \ldots$

Table 13. Rice straw quantity, availability, and price estimates $\ldots \ldots \ldots \ldots \ldots \ldots \ldots \ldots \ldots \ldots$

Table 14. Publication dates for state primary mill residue data $\ldots \ldots \ldots \ldots \ldots \ldots \ldots \ldots \ldots$

Table 15. Residue conversion factors for secondary forest products industry establishments . . . . 35

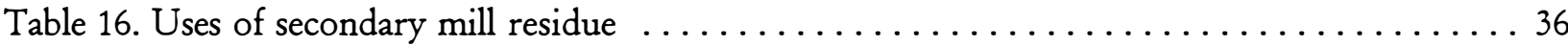

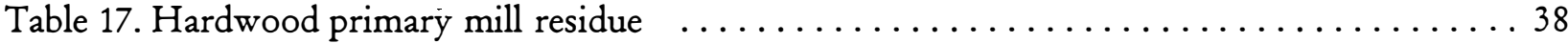

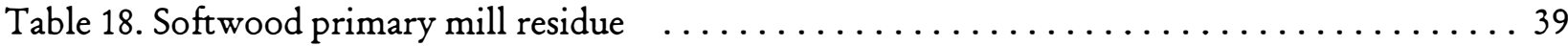

Table 19. Hardwood secondary mill residue $\ldots \ldots \ldots \ldots \ldots \ldots \ldots \ldots \ldots \ldots \ldots \ldots \ldots \ldots \ldots \ldots \ldots$

Table 20. Softwood secondary mill residue.$\ldots \ldots \ldots \ldots \ldots \ldots \ldots \ldots \ldots \ldots \ldots \ldots \ldots \ldots$

Table 21. Total paper pulp, total sludge, deink pulp, deink sludge production estimates,

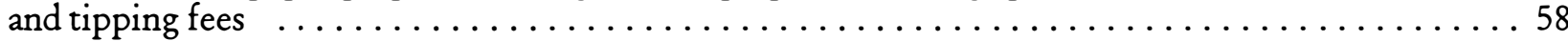

Table 22. Brewery production capacity classes $\ldots \ldots \ldots \ldots \ldots \ldots \ldots \ldots \ldots \ldots \ldots \ldots \ldots \ldots \ldots \ldots$

viii 


\section{Tables (con't)}

Table 23. 1996 beer and annual spent grain production among brewery sizes

for the United States . . . . . . . . . . . . . . . . . . . . . . . . . . 62

Table 24.1996 spent brewers grain prices by state $(\$ /$ dry ton $) \ldots \ldots \ldots \ldots \ldots \ldots \ldots \ldots \ldots \ldots$

Table 25 . Spent brewers grain adjusted annual quantity estimates $\ldots \ldots \ldots \ldots \ldots \ldots \ldots \ldots$

Table 26. Sugarcane bagasse technically and economically viable yields, and residue production

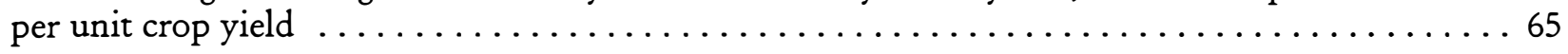

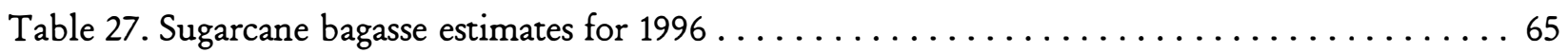

Table 28. Generated and recovered MSW, newsprint, and mixed office paper $\ldots \ldots \ldots \ldots \ldots 71$

Table 29. Average prices for mixed paper and newsprint $\ldots \ldots \ldots \ldots \ldots \ldots \ldots \ldots \ldots$

Table 30. National UTR survey results $\ldots \ldots \ldots \ldots \ldots \ldots \ldots \ldots \ldots \ldots \ldots \ldots \ldots$

Table 31. UTR conversion factors $\ldots \ldots \ldots \ldots \ldots \ldots \ldots \ldots \ldots \ldots \ldots \ldots \ldots \ldots$

Table 32. UTR 1993 annual production, by residue type (1,000 dry tons/year $) \ldots \ldots . \ldots 80$

Table 33 . Estimated UTR availability by region $\ldots \ldots \ldots \ldots \ldots \ldots \ldots \ldots \ldots \ldots \ldots \ldots$

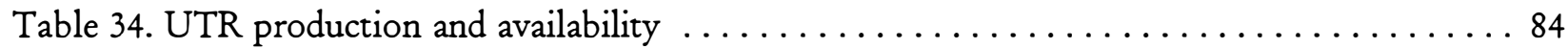

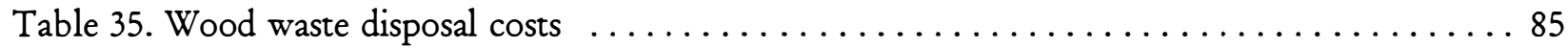

Table 36. Summary of 1996 available feedstock quantity and price (ranked by price) $\ldots \ldots \ldots 8$

Table A-1. Agricultural machinery speed and efficiency equation coefficients $\ldots \ldots \ldots \ldots$ A-2

Table A-2. Machine speed and efficiency values for corn stover cost calculation in Arkansas .... A-4

Table A-3. Corn stover owner-operator crop residue harvesting input costs $\ldots \ldots \ldots \ldots$ A-6

Table A-4. Agricultural residue cost assumptions $\ldots \ldots \ldots \ldots \ldots \ldots \ldots \ldots \ldots \ldots \ldots \ldots$

Table A-5. Small grain straw and rice straw owner-operator crop residue harvest budget sheet $\ldots$ A-7

Table A-6. Hay-alfalfa straw agricultural chemical, fertilizer, real estate tax, and land value . . . A A-8

Table A-7. Hay-alfalfa cost assumptions $\ldots \ldots \ldots \ldots \ldots \ldots \ldots \ldots \ldots \ldots \ldots \ldots \ldots \ldots \ldots$

Table B-1. Secondary forest products industry SIC classifications $\ldots \ldots \ldots \ldots \ldots \ldots \ldots \ldots$ B-2

Table C-1. Number and distribution of breweries for which capacity was not reported ..... C-2

Table C-2. Large brewery locations, production capacity, and contacts. . . . . . . . C-3

Table C-3. Regional brewery locations, production capacity, and contacts $\ldots \ldots \ldots \ldots$ C-4 


\section{Figures}

Page

Figure 1. Total corn gluten feed production in $1996(1,000$ dry tons/year $) \ldots \ldots \ldots \ldots \ldots \ldots 9$

Figure 2. Total corn gluten feed production in $1996(1,000$ dry tons/year $) \ldots \ldots \ldots \ldots \ldots \ldots$

Figure 3. Total distillers dried grain and solubles production in 1996 (1,000 dry tons/year) . . . 12

Figure 4. Total corn stover production in $1996(1,000$ dry tons/year $) \ldots \ldots \ldots \ldots \ldots \ldots 20$

Figure 5. Available corn stover in $1996(1,000$ dry tons/year $) \ldots \ldots \ldots \ldots \ldots \ldots \ldots \ldots . \ldots 21$

Figure 6. Total small grain straw production in 1996 (1,000 dry tons/year) . . . . . . . . . . 25

Figure 7. U.S. hay price indices: 1939 to present (base year 1900) $\ldots \ldots \ldots \ldots \ldots \ldots \ldots \ldots . \ldots 26$

Figure 8. Total hay-alfalfa straw production in $1996(1,000$ dry tons/year $) \ldots \ldots \ldots \ldots \ldots 28$

Figure 9. Available hay-alfalfa straw in $1996(1,000$ dry tons/year $) \ldots \ldots \ldots \ldots . \ldots . \ldots 29$

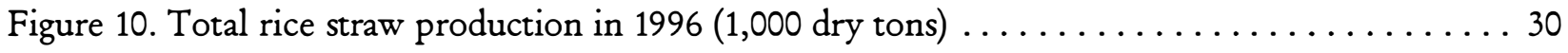

Figure 11. Available rice straw in $1996(1,000$ dry tons $) \ldots \ldots \ldots \ldots \ldots \ldots \ldots \ldots \ldots \ldots \ldots \ldots$

Figure 12. USDA forest service data reporting regions $\ldots \ldots \ldots \ldots \ldots \ldots \ldots \ldots \ldots \ldots \ldots \ldots$

Figure 13. Total hardwood primary mill residue production $(1,000$ dry tons/year $) \ldots \ldots \ldots \ldots 40$

Figure 14. Hardwood primary mill residue used in non-captive markets (1,000 dry tons/year) . . . 41

Figure 15. Recoverable unused hardwood primary mill residue $(1,000$ dry tons/year $) \ldots \ldots \ldots \ldots 42$

Figure 16. Total softwood primary mill residue production $(1,000$ dry tons/year $) \ldots \ldots \ldots \ldots 43$

Figure 17. Softwood primary mill residue used in non-captive markets (1,000 dry tons/year) . . . . 44

Figure 18. Recoverable unused softwood primary mill residue $(1,000$ dry tons/year $) \ldots \ldots \ldots 45$

Figure 19. Total hardwood secondary mill residue production $(1,000$ dry tons/year $) \ldots \ldots \ldots 50$

Figure 20. Hardwood secondary mill residue used in non-captive markets (1,000 dry tons/year) . . 51

Figure 21. Recoverable unused hardwood secondary mill residues $(1,000 \mathrm{dry}$ tons/year) . . . . . 52

Figure 22. Total softwood secondary mill residue production $(1,000$ dry tons/year) $\ldots \ldots \ldots \ldots 53$

Figure 23. Secondary softwood mill residues used in non-captive markets (1,000 dry tons/year) ․ 54

Figure 24. Recoverable unused softwood secondary mill residues $(1,000$ dry tons/year $) \ldots \ldots \ldots 55$

Figure 25. Total recycled primary paper pulp sludge production in 1996 (1,000 dry tons/year) . . . 59 


\section{Figures (con't)}

Figure 26. Available recycled primary paper pulp sludge in 1996 (1,000 dry tons/year) . . . . . 60

Figure 27. Total spent brewers grain production in 1996 (1,000 dry tons/year) . . . . . . . . 64

Figure 28. Total sugarcane bagasse production in 1996 (1,000 dry tons/year) . . . . . . . 67

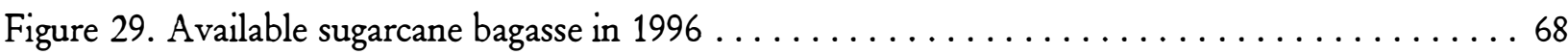

Figure 30. Total newsprint production in $1996(1,000$ dry tons/year $) \ldots \ldots \ldots \ldots \ldots \ldots$

Figure 31. Available newsprint in 1996 (1,000 dry tons/year $) \ldots \ldots \ldots \ldots \ldots \ldots \ldots$

Figure 32. Total mixed office paper production in 1996 (1,000 dry tons/year) $\ldots \ldots \ldots \ldots$

Figure 33. Available mixed office paper in 1996 (1,000 dry tons/year $) \ldots \ldots \ldots \ldots \ldots \ldots$

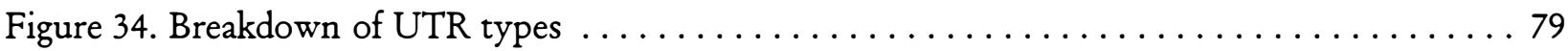

Figure 35. UTR production by generator type $\ldots \ldots \ldots \ldots \ldots \ldots \ldots \ldots \ldots \ldots \ldots \ldots$

Figure 36. Disposal methods for UTR chips $\ldots \ldots \ldots \ldots \ldots \ldots \ldots \ldots \ldots \ldots \ldots \ldots \ldots \ldots$

Figure 37. End use of UTR chips that are sold $\ldots \ldots \ldots \ldots \ldots \ldots \ldots \ldots \ldots \ldots \ldots \ldots \ldots$

Figure 38 . Residue disposal method by DOE RBEP regions $\ldots \ldots \ldots \ldots \ldots \ldots \ldots \ldots \ldots \ldots$

Figure 39. Total urban tree residue production $(1,000$ dry tons/year $) \ldots \ldots \ldots \ldots \ldots$

Figure 40 . Available urban tree residue $(1,000$ dry tons/year $) \ldots \ldots \ldots \ldots \ldots \ldots \ldots \ldots$ 


\section{Introduction}

\section{Background}

The U.S. Department of Energy's (DOE) Office of Fuels Development (OFD) and the National Renewable Energy Laboratory's(NREL) Biofuels Program are developing technology for converting lignocellulosic resources into ethanol as a liquid transportation fuel. The technology has matured to the point at which commercialization efforts by OFD and the Biofuels Program are now being undertaken.

The Biofuels Program at NREL andDOE/OFD has developed a multiyear technical planfor commercializing biomass-to-ethanol technology. As part of this plan, OFD and the Biofuels Program developed an initial list of feedstock selection criteria for ranking potential feedstocks. The initial ranking efforts divided the resource into two basic groups:

- Feedstocks such as pine, spruce, fir, juniper, cypress, and hemlock (gymnosperms) that consist primarily of six-carbon sugars.

- Feedstocks such as hardwood trees, grasses, agricultural residue, and agricultural waste (angiosperms) that consist primarily of five- and six-carbon sugars.

A finding of the initial ranking effort was that there was a lack of basic resource information on many feedstocks used in the selection criteria. Private sector companies and state energy offices often approach the BiofuelsProgram and OFD with feedstock-driven opportunities. Although these niche opportunities could be important in commercialization efforts, the resources must be large enough to warrant further investigation.

NREL has undertaken this project in an effort to address the lack of information on potential feedstocks. The objectives are to (1) produce a resource document, using currently available information, that describes the distribution, quantity, availability, competing uses, and current market value of select lignocellulosic biomass feedstocks in the United States; and (2) identify where data are lacking. The following feedstocks are included in the study and defined later in the report:

- Corn fiber

- Corn stover

- Grass straw

- Hardwood primary sawmill waste

- Hardwood secondary processing waste

- Softwood primary sawmill waste

- Softwood secondary processing waste

- Recycled paper primary sludge

- Small grains straw

- Spent grain from the malt and brewing industry

- Sugarcane bagasse

- Wastepaper

- Urban yard waste (wood).

This report, along with the underlying data, provides the results and documentation of the lignocellulosic resource assessment effort. It contains the most current state-level information by feedstock type.

\section{Intended Audience}

The intended audience of this report is professionals at NREL, DOE, state energy offices, universities, and others who have an interest in the use of lignocellulosic biomass resources. We anticipate that the information presented here will be used as a macro-level screening tool rather than as a biomass plant siting tool. 


\section{Report Structure}

The report is structured to provide a concise source of information on the location, quantities, costs, and competing uses for the lignocellulosic resources included in the assessment. It begins with a general listing and description of each feedstock included in the study. This is followed by a discussion on the methodology used to develop the data and report. The methodology section includes a description of data sources and the approach followed to gather data.

The data and results of the project are organized by feedstock type, with a separate section for each feedstock. The beginning of each feedstock section contains the following feedstock-specific general information:

- Feedstock definition

- Discussion of data sources

- Description of analytic methods

- Discussion of data quality.

The feedstock distribution and quantity data are presented through a series of state-level maps and tables. Each feedstock section also contains information on resource availability, competing uses, and current market values. The report ends with a discussion of conclusions.

Data in this document are (except for price information for corn fiber and spent brewers grains) from current sources. The names of producers contacted for price information are kept confidential to protect the proprietary nature of their answers. Data are presented in a standard format to facilitate manipulation, analysis, and display. Quantities and prices are in 1,000 dry tons and \$/dry ton, respectively. Feedstock data are presented at the state level, although underlying databases for feedstocks from field crops contain data at the county level. The software packages used include:

- Microsoft Excel

- Microsoft Access

- Microsoft Word

- ArcView

- SPSS.

Maps and data are suitable for targeting and ranking states as potential candidates for biomass-based ethanol manufacturing facilities. The results can help identify feedstocks that are promising for continued ethanol process research and technology transfer both from an economic and a technical standpoint. Although the data in this report are sound estimates, decisions as to whether a cellulose-to-ethanol facility should be constructed will require feasibility studies, similar to those being undertaken by groups such as the Quincy Library Group (Quincy, California) and the Front Range Forest Health Partnership (Denver, Colorado). Detailed, local resource assessments must accompany a comprehensive feasibility study before specific decisions regarding construction of a biomass-to-ethanol facility can be made.

\section{Data Acquisition}

A detailed literature and Internet search provided most of the data used to generate the maps and tables that accompany this report. Regional industry and government experts provided, and in some instances verified, price and quantity data where such data were not collected. A variety of published government and industry reports contributed to the assessment of the quantity, availability, and prices of lignocellulosic feedstocks on a state level. See the References section of this report for a detailed list of publications used in the analysis.

Organizations that contributed data and/or information to the report included the Corn Refiners Association (CRA), the U.S. Department of Commerce (DOC), U.S. Department of Agriculture (USDA) National Agricultural Statistics Service (NASS), USDA Economic Research Service (ERS), Iowa State Cooperative Extension Service, 
University of Minnesota Cooperative Extension Service, Illinois State Cooperative Extension Service, Louisiana State University Cooperative Extension Service, Minnesota Department of Natural Resources, USDA Forest Service, the American Forest and Paper Association, NREL, the DOE Energy Information Administration (EIA), Franklin Associates, the U.S. Environmental Protection Agency (EPA), Tennessee Valley Authority (TVA), Feedsuffs staff, Biocycle staff, Wood Technology (Lockwood Post Directories), the Institute for Brewing Studies, the International Society of Arboriculture Research Trust, NEOS Corporation, various industry representatives, state energy offices, extension agencies, state foresters, and university researchers.

DOC and CRA provided data on com milling establishments and employment, allowing the assembly of disribution, quantity, and availability maps of residues produced as by-products of these operations.

USDA NASS provided state-level crop acreage and yield data for small grains (oats, rye, barley, wheat, and sorghum), com, rice, hay-alfalfa, and sugarcane. Published information from NREL provided estimates of crop residue production per unit of crop yield. This approach allowed for calculating residue production on a state level from crop acreage and yield data. The methodology used to estimate total and available crop residue was intended to identify quantities that can be:

- Removed without compromising soil productivity of farmland

- Harvested for additional net revenue to the farmer

- Obtained using commonly owned and operated farm equipment.

Prices for agricultural residues were estimated using an economic engineering approach, including a return on capital and land, opportunity costs for farm labor, and the nutrient value of residues removed.

EIA input data for national energy supply/price models provided primary mill residue production and prices. Detailed Minnesota Department of Natural Resources waste wood surveys provided information that, in combination with DOC data on secondary mill residue establishments, allowed residue production to be estimated from the secondary forest products industry. Regional price information for primary and secondary mill residues was obtained from EIA. Sources for EIA price information included a variety of industry, government, and university research organizations.

The Brewers Resource Directory, compiled by the Institute for BrewingStudies in Boulder, Colorado, supplied brewery capacity data that allowed estimation of spent grain distribution and quantity. Telephone and written correspondence with various government agencies, industry representatives, dairy consultants, and commodities specialists provided price information for spent grains.

Wastepaper data were extracted from a variety of industry and trade association publications, including industry association, EPA, and USDA Forest Service publications. Urban wood waste data were obtained from recent (1993-1994) nationwide surveys of urban waste wood production and disposition, as well as contacts with industry and trade associations. 


\section{Feedstock Descriptions}

This section contains a brief characterization of each feedstock type, including a physical description, typical energy content, and moisture content. Table 1 shows some typical values for moisture and energy content for each feedstock type. This information is provided as general background only, and is not intended as a substitute for more detailed analysis of location-specific feedstocks. The ethanol yield per ton of feedstock will vary by process and feedstock type.

Current average energy output for ethanol using corn as a feedstock is $33 \%$ higher than the energy input; the best output is $87 \%$ higher than energy input (A bmed and Morris 1992). The feedstock energy content is only a general reflection of the potential ethanol yields; carbohydrate composition and conversion process play larger roles in conversion efficiency.

Table 1. Typical energy content (Btu/lb) moisture content percent for lignocellulosic feedstocks

\begin{tabular}{|c|c|c|}
\hline retestouls & 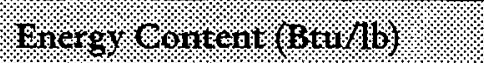 & 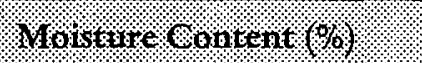 \\
\hline Corn fiber & $7,920^{1}$ & $20 \%-30 \%{ }^{1}$ \\
\hline Corn stover & $7,523^{1}$ & $7 \%-22 \%{ }^{2}$ \\
\hline \multicolumn{3}{|l|}{ Small grain straw } \\
\hline Oats & $7,500^{3}$ & $10 \%-20 \%{ }^{4}$ \\
\hline Barley & $7,447^{1}$ & $13.8 \%^{1}$ \\
\hline Wheat & $7,533^{1}$ & $10 \%-20 \%{ }^{4}$ \\
\hline Rye & $7,500^{3}$ & $10 \%-20 \%^{4}$ \\
\hline Sorghum & $7,541^{5}$ & $10 \%-20 \%{ }^{4}$ \\
\hline Grass straw & $7,937^{1}$ & $10 \%-20 \%{ }^{4}$ \\
\hline Rice straw & $6,264^{2}$ & $10 \%-20 \%{ }^{4}$ \\
\hline Hardwood residues & $8,530^{6}$ & $38 \%-50 \%{ }^{6}$ \\
\hline Softwood residues & $8,910^{6}$ & $58 \%-61 \%^{6}$ \\
\hline Paper pulp sludge & $8,100-8,370^{1,9}$ & $56 \%-92 \%^{7}$ \\
\hline Spent grains & not available & $70 \%-80 \%$ \\
\hline Sugarcane bagasse & $8,188^{1}$ & $46 \%-52 \% 1$ \\
\hline \multicolumn{3}{|l|}{ Wastepaper } \\
\hline Newsprint & $7,979^{1}$ & $6 \%^{1}$ \\
\hline Office paper (mixed) & $7,200^{8}$ & $4 \%-6 \%{ }^{1}$ \\
\hline Urban wood waste & $4,500-7,500^{8}$ & $10 \%-60 \% \%^{8}$ \\
\hline
\end{tabular}

1 Domalski and Lobe (1986)

${ }^{2}$ Mahanna et al. (1996)

${ }^{3}$ Fox (1987)

${ }^{4}$ Turhollow et al. (1996)

${ }^{5}$ Worley and Cundiff (1992)
${ }^{6}$ Miyata and Miyata (1981)

7 Kerstetter et al. (1997)

${ }^{8}$ OCRRA (1993); Smith (1995)

${ }^{9}$ Sulfite process, $55 \%$ solids non-neutralized spent liquor 


\section{Corn Fiber}

The by-products of corn wet milling are corn gluten feed (CGF) and corn gluten meal (CGM). The by-products of corn dry milling are distillers dried grains (DDG). Corn fiber consists of CGF, CGM, and DDG.

In the wet milling process, each corn kernel is separated into three component parts: germ, starch, and hull. From the germ comes corn oil. Starch is the feedstock for ethanol (ethyl alcohol), fructose, corn syrup, and corn starch. The hull, or bran, is fibrous, consisting of cellulose (3\%), hemicellulose (6\%), and sugars (2\%) (NREL 1993). The hull is combined with other residue from the wet milling process to become CGF or CGM. Livestock producers use CGF and CGM as livestock feed ingredients. Because CGM has a higher protein content than CGF, it is more desirable as feed and commands prices that are three- to fourfold higher.

Dry corn milling produces ethanol, corn meal, and other food ingredients. In the ethanol production process, com is cleaned, milled (usually ground by hammermills), mixed with water into a slurry, and cooked to gelatinize the starch and sterilize the mixture. Once cooked, the mixture is cooled, dosed with enzymes for starch saccharification, and inoculated with yeast. When the yeast fermentation is complete, the resulting ethanol is distilled from the fermented mash. The remaining residue, called wet stillage, is either used locally as livestock feed (a small percentage) or dried to produce DDG.

Processes can increase ethanol yields by using CGF, CGM, and DDG for ethanol production rather than for supplemental animal feed (U.S. Feed Grains Council 1996).

\section{Data Sources and Methodology}

CRA and the U.S. Bureau of the Census provided information required to estimate the amount of com fiber produced annually by wet corn milling facilities. CRA contributed mill locations for all member companies plus one mill that belongs to a nonmember company. CRA claimed that only one wet corn mill was not a member of its organization. In its annual industry update, CRA published 1996 national wet milling industry shipment figures for all corn products, including CGM and CGF (CRA 1997). Livestock producers use CGM and CGF within a several-month period after production to prevent spoilage. Therefore, shipment data accurately assess the total amounts of CGM and CGF produced.

The U.S. Bureau of the Census provided total employment and establishment counts for facilities classified within Standard Industrial Code (SIC) 2046, including wet corn milling and other vegetable starch production facilities. Starch production facilities that use raw materials other than corn were eliminated by cross-referencing the number of wet corn milling facilities with census information. The U.S. Bureau of the Census provided state-level counts of the total number of facilities in each of eight employment size classifications $(1-4,5-9,10-19,20-49,50-99$, 100-249, 250-499, and 500+ employees). Plants with fewer than 50-99 employees are not likely to be involved in corn wet milling (Schwartz 1997). Only plants in the 50-99 employee size classification or higher were assumed to be wet milling facilities and used to estimate CGM and CGF production levels.

With the smaller plants eliminated, the remaining plants in each state could be correlated to the wet milling plants on the CRA member list. The number of wet milling plants in census data matched the CRA wet milling plant list with a discrepancy of two plants. This allowed for a cross-check on CRA data on the number of establishments per state. Com fiber production was estimated using statewide employment by com milling operations and average production per employee. State employment was estimated as the sum of the number of plants in each class by the median number of employees in each size class.

Average production per employee was obtained by dividing total U.S. production by thetotal number of employees on a state level. For example, total CGF production in the United States was 5,664,500 dry tons. Dividing this by com wet milling employment in Iowa equal to 2,310 gave a peremployee CGF production of 2,452.2 dry tons. 
USDA Economic Research Service representatives supplied average 1996 CGM and CGF market prices for 4 years (USDA Economic Research Service 1997). Because corn wet milling facilities are concentrated in the central United States, prices for CGF and CGM were available only for markets within this region.

DDG production from dry milling operations was determined indirectly by idencifying ethanol production capacity. Dry milling operations are used almost exclusively for producing industrial ethanol (NREL 1993). Ethanol plant capacity information was available from two sources. The Renewable Fuels Association (RFA) and Information Resources, Inc. (IRI), provided lists of U.S. ethanol plants with production capacities (RFA 1997; IRI 1997). These lists included ethanol plants that used either the wet or dry milling process. All ethanol plants using the wet milling process were identified from the CRA wet milling plant list and removed to determine the location and capacity of dry milling operations. In addition, one CRA nonmember dry milling facility was identified. DDG production was estimated for the remaining mills based on mill ethanol capacity. Each bushel of corn yields approximately 2.6 gallons of ethanol and 19 pounds ofDDG (Sneller 1997). Whenever RFA and IRI listings showed discrepancies in plant capacity, IRI data were used because they were specific to each plant, whereas the RFA often provided only one capacity figure for several plants owned by the same company. Once the DDG production for each mill was estimated, aggregate state values were compiled. DDG average market prices were obtained for 4 market years (USDA Economic Research Service 1997).

\section{Results and Discussion}

This section contains the results of corn fiber data collection and analysis. Included are quantity maps, quantity data, and price data.

\section{CGM and CGF Quantity and Price}

CRA reports shipment data from individual member companies annually. The corn wet milling industry is highly concentrated; 11 firms own and operate all establishments in the United States (CRA 1997). Production is concentrated in the midwestern and Great Plains states as expected. Figures 1 and 2 show statewide CGF and CGM production in 1996.

Wet corn refining production capacity in each state is the product of the percent of total wet mill production in each state (Table 2) and total U.S. capacity. Employment estimates are approximate; they use the median of the U.S. Census Bureau's employee size classifications. For example, a plant that falls within the 250-499 employee size classification is considered to have 375 employees, although it could have as few as 250 or as many as 499. The accuracy of state-level estimates is not as high as it would be if firms were willing to divulge production by mill, but such information is highly proprietary, given the corn wet milling industry's level of concentration.

Table 2 shows the wet corn mill count, employment, and CGF/CGM production by state. CGM and CGF quantity data are incorporated into distribution and quantity maps.

Published CGM and CGF price data are given in Table 3. Prices vary seasonally and annually. Transport costs often limit the market area for CGM and CGF to 200 miles from the point of origin (Chandler 1991). CGM and CGF prices vary extensively with grain prices (CRA 1997).

Because of its high protein content, CGM is priced higher than CGF. CGM is typically provided at $60 \%$ protein, whereas CGF is provided at 20\% (CRA 1989). CGF is often dried and pelletized for feed purposes. Wet CGF is typically provided at 60\% moisture content (wet basis) (CRA 1989). 
Table 2. 1996 wet corn mill count by state, mill employee size class, estimated total state employment, and CGF/CGM production

\begin{tabular}{|c|c|c|c|c|c|c|}
\hline Strate. & Wimber sol: & 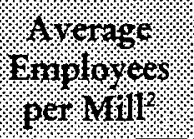 & 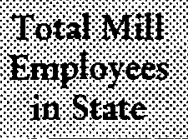 & 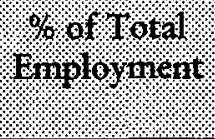 & 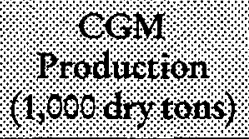 & 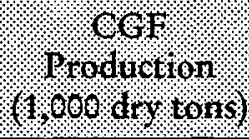 \\
\hline $\mathrm{AL}$ & 1 & 175 & 175 & $2.1 \%$ & 24.0 & 121.4 \\
\hline $\mathrm{CA}$ & 1 & 75 & 75 & $0.9 \%$ & 10.2 & 51.8 \\
\hline IA & 7 & 330 & 2,310 & $28.4 \%$ & 317.8 & $1,607.4$ \\
\hline IL & 4 & 356 & 1,424 & $17.5 \%$ & 195.9 & 990.9 \\
\hline IN & 3 & 437 & 1,311 & $16.1 \%$ & 180.3 & 912.2 \\
\hline $\mathbf{M N}$ & 1 & 175 & 175 & $2.1 \%$ & 24.0 & 121.4 \\
\hline MO & 1 & 175 & 175 & $2.1 \%$ & 24.0 & 121.4 \\
\hline NC & 1 & 175 & 175 & $2.1 \%$ & 24.0 & 121.4 \\
\hline ND & 1 & 256 & 256 & $3.1 \%$ & 35.3 & 178.3 \\
\hline NE & 2 & 256 & 513 & $6.3 \%$ & 70.5 & 356.6 \\
\hline NY & 1 & 256 & 256 & $3.1 \%$ & 35.3 & 178.3 \\
\hline $\mathrm{OH}$ & 1 & 375 & 375 & $4.6 \%$ & 51.5 & 260.6 \\
\hline TN & 2 & 375 & 749 & $9.2 \%$ & 103.0 & 521.2 \\
\hline $\mathrm{TX}$ & 1 & 175 & 175 & $2.1 \%$ & 24.0 & 121.4 \\
\hline $\begin{array}{l}\text { Totals/ } \\
\text { Average }\end{array}$ & 27 & 256 & 8,141 & $100.0 \%$ & $1,119.8$ & $5,664.5$ \\
\hline
\end{tabular}

${ }^{1}$ CRA (1997)

${ }^{2}$ U.S. Department of Commerce (1997)

Table 3. Average CGM and CGF prices (\$/dry ton $)^{1}$

\begin{tabular}{|c|c|c|}
\hline Marker lear & ogl & 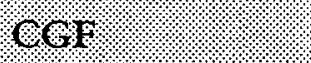 \\
\hline 1993-1994 & $\$ 286.61$ & $\$ 88.62$ \\
\hline 1994-1995 & $\$ 221.95$ & $\$ 82.77$ \\
\hline 1995-1996 & $\$ 319.35$ & $\$ 116.47$ \\
\hline 1996-1997 & $\$ 341.50$ & $\$ 93.05$ \\
\hline Average & $\$ 292.35$ & $\$ 95.23$ \\
\hline
\end{tabular}

${ }^{1}$ USDA Economic Research Service (1997) 


\section{DDG Quantity and Price}

Table 4 gives dry mill ethanol capacities and corresponding DDG statewide production estimates. RFA and IRI sources, used to identify dry milling operations, are updated periodically as plants close, new plants open, and capacities change. EIA data indicate that maximum ethanol production levels were reached in 1995 . These levels can be assumed to be very close to the maximum production capacity of present U.S. ethanol facilities. Although ethanol production dipped in 1996 because of high grain prices and low oil prices, industry projections for 1997 production exceed 1.4 billion gallons, which approaches the record production level of 1995 (RFA 1997).

Total 1996 DDG production estimates are shown in Figure 3. Like the corn wet milling industry, the dry milling industry is highly concentrated among a small number of producers. The 1996 ethanol data provide a conservative estimate of com fiber production from DDG. Using 1995 or 1997 ethanol production levels could allow estimates that more closely approximate maximum U.S. DDG production capacity.

Table 5 presents DDG prices for 1995-1996, 1996-1997, and 1997 YTD from government and industry sources. Because of the dip in ethanol production in 1996, the market prices for DDG rose sharply duning the first part of the year. The prices returned to normal in late 1996 and 1997. Because of the abnormally high prices in early 1996, the YTD (to October 1997) and 1996-1997 market year prices for DDG are more representative of the current market prices.

California prices were higher than those in other regions during 1995-1996 and 1996-1997 market years because of export markets for feed products. For 1997 YTD, Kansas City, Missouri, DDG prices were highest. DDG prices are higher than CGF prices because of their high feed value. 


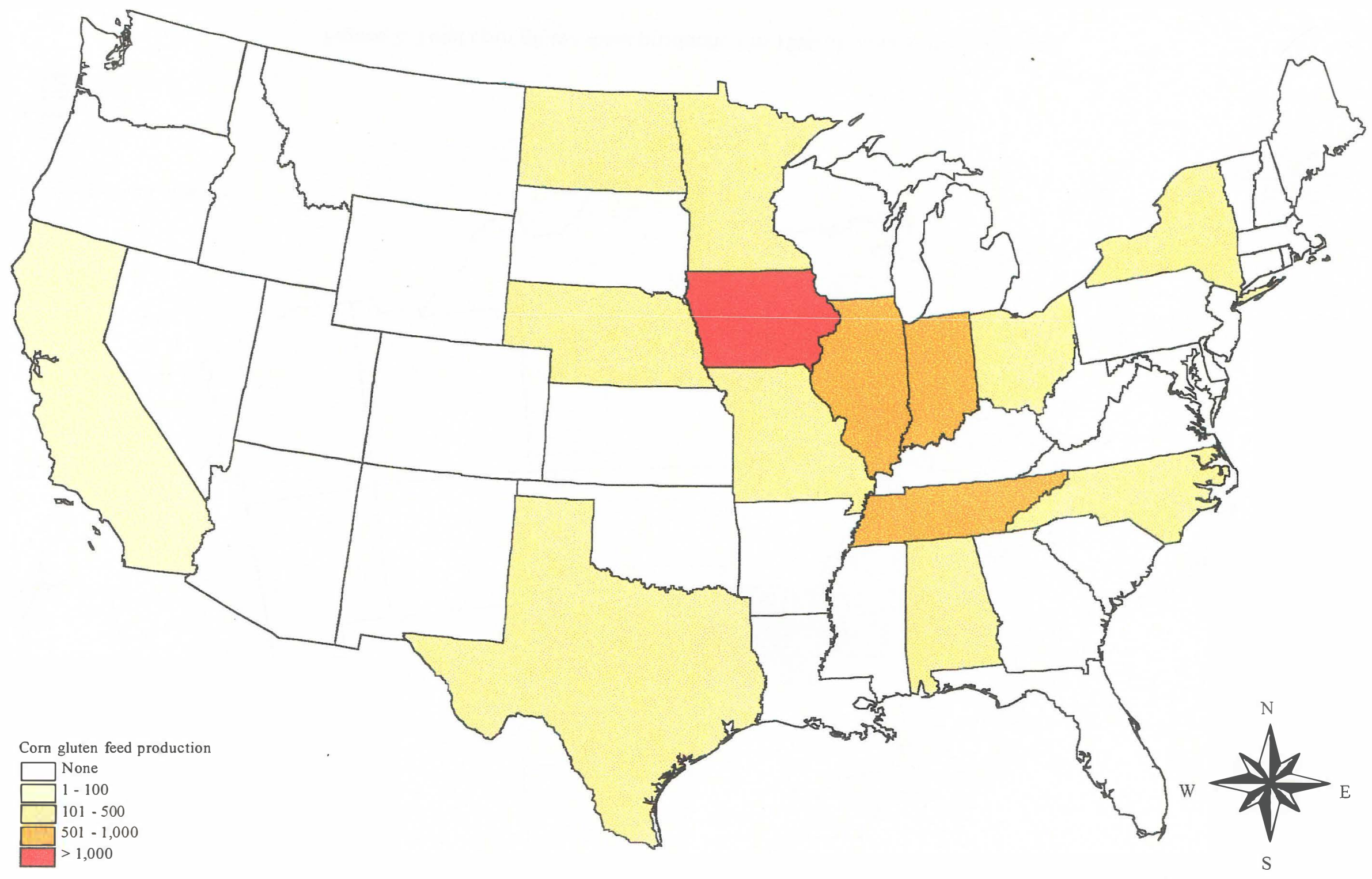

Figure 1. Total corn gluten feed production in 1996 (thousand dry tons/year) 


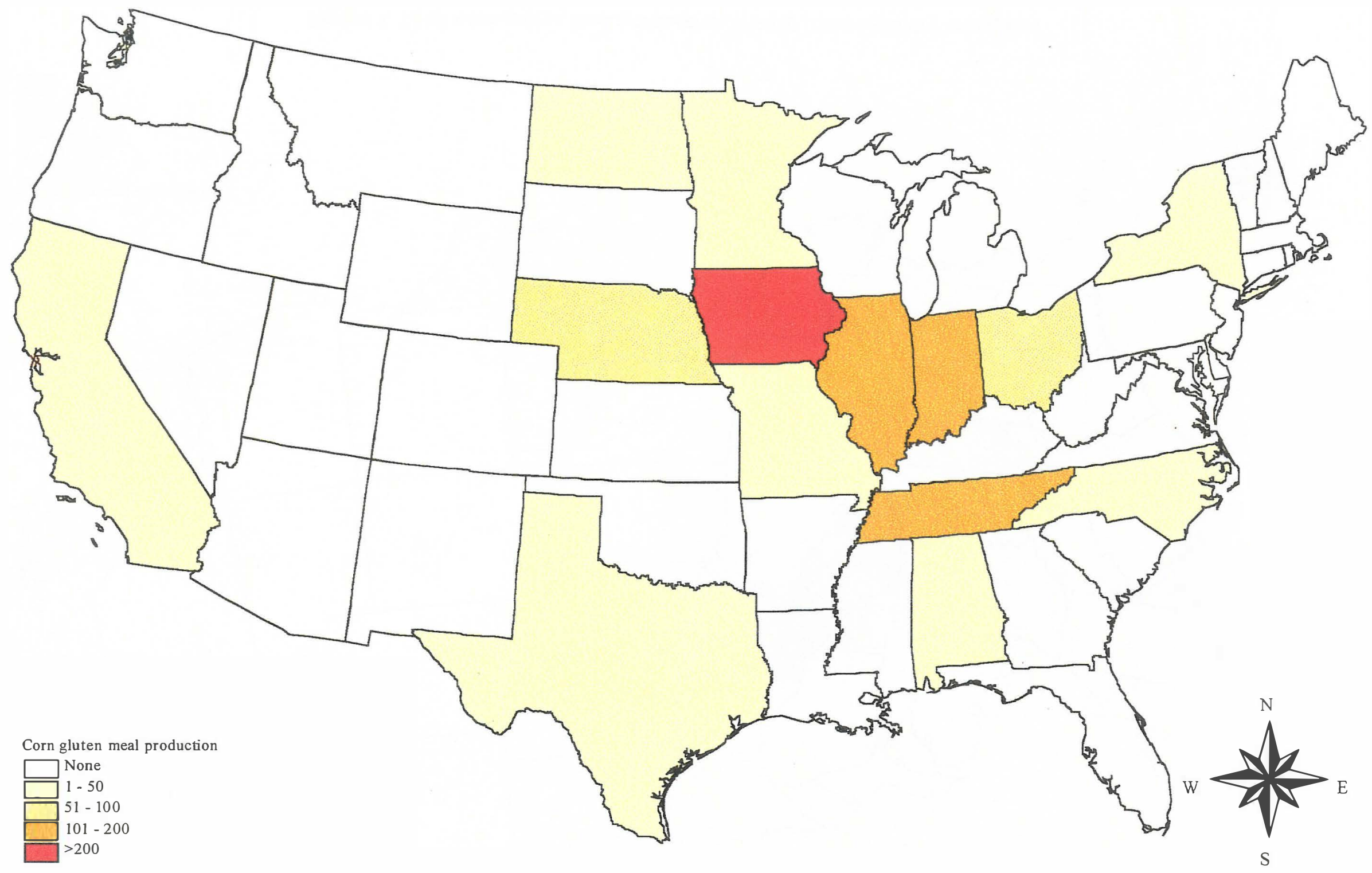

Figure 2. Total corn gluten meal production in 1996 (thousand dry tons/year) 
Table 4. 1996 dry mill ethanol capacity (1,000,000 gallons/year) and estimated DDG production (1,000 dry tons/year) by state

\begin{tabular}{|c|c|c|}
\hline Sitater. & 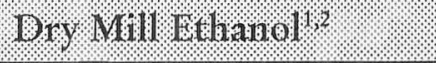 & 1) \\
\hline IA & 7.5 & 27.4 \\
\hline ID & 7.0 & 25.6 \\
\hline IL & 112.5 & 411.1 \\
\hline IN & 75.0 & 274.0 \\
\hline $\mathrm{KS}$ & 35.4 & 129.3 \\
\hline $\mathrm{KY}$ & 10.0 & 36.5 \\
\hline $\mathrm{MN}$ & 79.1 & 289.0 \\
\hline MT & 2.0 & 7.3 \\
\hline ND & 12.0 & 43.8 \\
\hline $\mathrm{NE}$ & 122.7 & 448.3 \\
\hline $\mathrm{SD}$ & 12.3 & 44.8 \\
\hline TX & 1.1 & 4.0 \\
\hline Total & 476.6 & 1741.1 \\
\hline
\end{tabular}

${ }^{1}$ Schwartz (1997)

${ }^{2}$ Schaffer (1997)

Table 5. Average DDG prices (\$/dry ton)

\begin{tabular}{|c|c|}
\hline Wrar Irer lear & Pirer \\
\hline 1993-1994 & $\$ 123.79$ \\
\hline 1994-1995 & $\$ 106.70$ \\
\hline 1995-1996 & $\$ 151.37$ \\
\hline 1996-1997 & $\$ 145.87$ \\
\hline Average & $\$ 131.93$ \\
\hline
\end{tabular}

'USDA Economic Research Service (1997)

California prices were higher than those in other regions during the 1995-1996 and 1996-1997 market years because of export markets for feed products. DDG prices are higher than CGF prices because of their high feed value. 


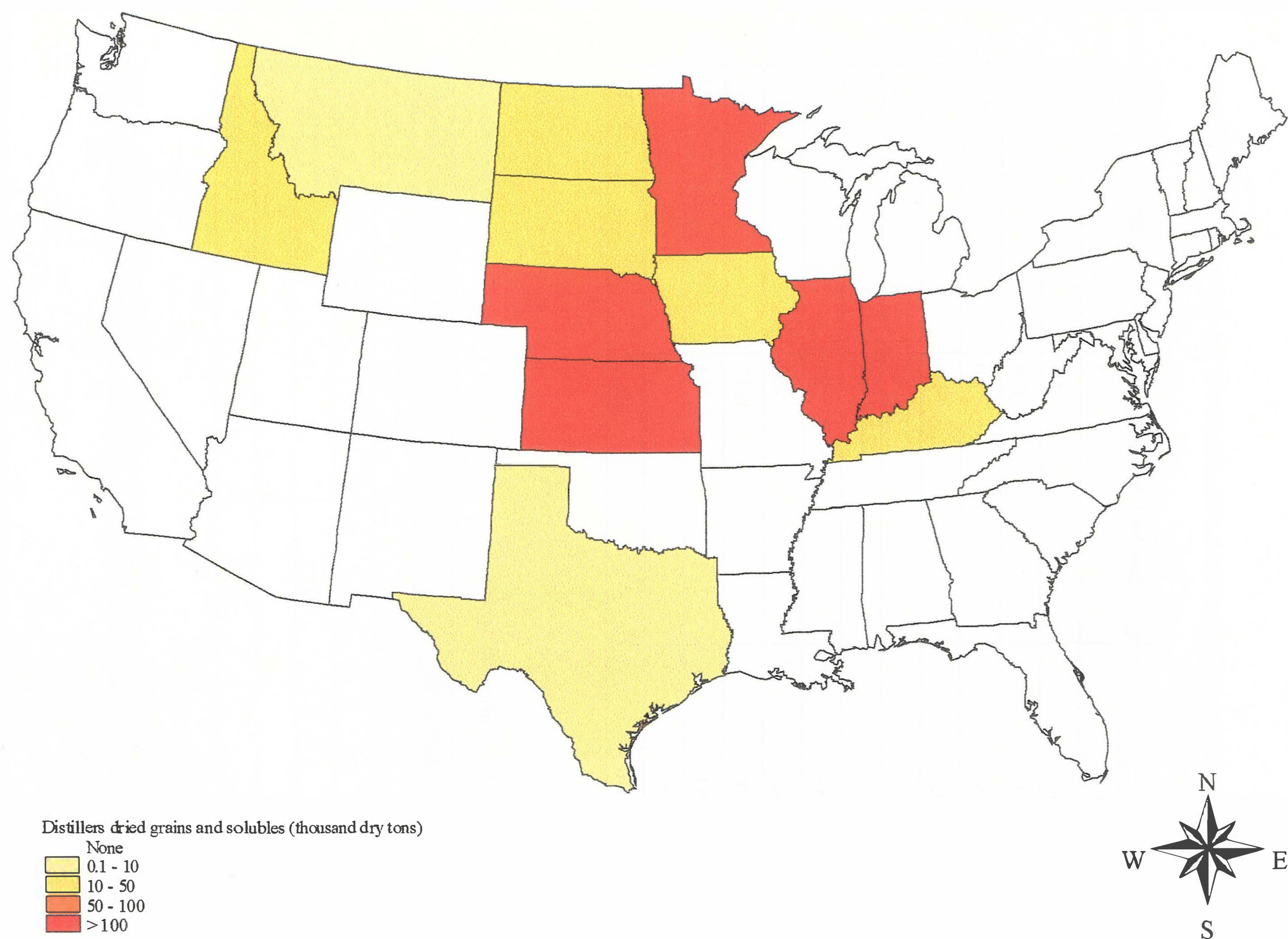

Figure 3. Total distillers dried grains and solubles production in 1996 (thousand dry tons/year) 


\section{Agricultural Crop Residues}

Agricultural crop residues considered in this report include corn stover, small grain straw, grass straw, and rice straw. Corn stover includes stalks, leaves and cobs left over following grain corn harvest. Small grain straw includes stalks and leaves left following oat, rye, barley, wheat and sorghum grain harvest. Grass straw includes hay and alfalfa grown for all purposes. Rice straw includes leaves and stalks left following rice harvest.

Except for several spot markets, there are no established commodity markets for many agricultural residues. In the absence of market prices, information on costs and profitability for agricultural residue collection and sale was developed to approximate market prices. Ultimately, consumer demand dictates the price to be paid for agricultural residues. However, a competitive marketplace is a dynamic equilibrium where a market opportunity will attract new market producers. Price competition between producers in a marketplace provides an incentive to drive down costs. In microeconomics, the marginal cost to produce a unit of a good and the unit price consumers are willing to pay are equal at an economic equilibrium. The marginal cost at this point corresponds to the cost at which the economic profit for a producer is equivalent to that available from alternative investments. This relationship between price, the cost of production, and profit potential is used to estimate the market price for agricultural residues in this study.

Costs associated with the production of agricultural crop residues include fixed costs, operating costs, and opportunity costs. Fixed costs include depreciation, interest, insurance, and housing for equipment used to collect residues. Land-related costs such as property taxes and depreciation of improvements are attributed to the primary crop production. One exception is hay-alfalfa. Costs for hay-alfalfa reflect property taxes and the value of land improvements because hay-alfalfa grown as an ethanol feedstock is assumed to be a dedicated energy crop. Operating costs include equipment fuel, labor, repairs, and maintenance costs. The combined values of the fixed and operating costs, and the opportunity costs of production are a gross approximation of the market price of agricultural residues in an established agricultural residuebased industry. Profitability for producers is based on estimates of the opportunity cost of producing agricultural residues. Opportunity costs represent the net income forgone by choosing to use equipment for residue collection rather than other production activities. In addition, the market price estimates incorporate estimates of the value of production value forgone be the removal of nutrients in residues. The opportunity costs in this study reflect accounting profit only, and not perceptions of risk.

A number of price formation variables are not accounted for in this study. It is beyond the scope of this study to depict farmer perceptions of risk and expectations of profitability on the scale represented here. A risk premium for market "pioneers" may be required as an incentive to attract entrepreneurial agricultural producers to collect residues. This premium is highly subjective, and can really only be evaluated for individual producers through negotiations to arrange the purchase of residues as an ethanol feedstock. The market scenario represented here most accurately depicts an agricultural residue market that is at an economic equilibrium. Agricultural markets often experience a time lag between an increase in demand for an agricultural commodity and a corresponding shift in supply. This lag is due to the need to alter production scheduling, planting patterns, climate, and a host of other factors. Although residue collection is unlikely to involve large changes in cropping patterns, any potential ethanol production investor should investigate local agricultural infrastructure to determine preliminary market development work that may be required to ensure a stable, economic feedstock supply. 


\section{Data Sources and Methodology}

Residue quantities were estimated using USDA NASS crop acreage and yield data collected in 1996 for each state in the conterminous United States. Crop yields were reported in bu/acre, with the following exceptions: hay (green tons/acre) and rice (lb/acre). Published conversion factors for residue yield per unit crop yield permitted estimation of production levels.

Quantity maps show the technically removable quantity of crop residues. "Technically removable" in this case refers to the amount of residue that can be removed with allowances for leaving some residue in the field to preserve soil productivity and prevent erosion. Technically removable quantities are based on consensus estimates developed by extension and USDA Natural Resources Conservation Service representatives (WRBEP 1991). In the absence of a published rye straw residue factor, the barley residue factor was substituted.

Table 6. Technically and economically viable residue yields, and residue per unit crop yield

\begin{tabular}{|c|c|c|c|}
\hline 9100 & 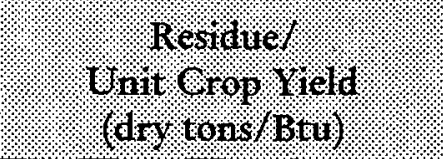 & 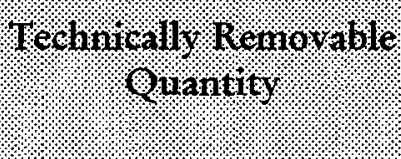 & 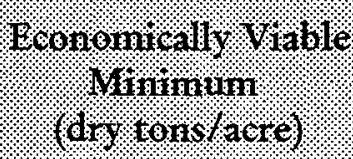 \\
\hline Corn & $0.028^{1}$ & Total 2 dry tons ${ }^{1}$ & 1 \\
\hline Wheat & $0.029^{2}$ & $35 \%$ of total $^{2}$ & 1 \\
\hline Sorghum & $0.024^{3}$ & $35 \%$ of total $^{2}$ & 1 \\
\hline Oats & $0.018^{2}$ & $35 \%$ of total $^{2}$ & 1 \\
\hline Rye/Barley & $0.024^{2}$ & $35 \%$ of total $^{2}$ & 1 \\
\hline Rice & 0.0005 (dry tons/ton yield) & $35 \%$ of total $^{2}$ & 1 \\
\hline Hay-alfalfa & $\mathrm{n} / \mathrm{a}$ & $60 \%$ of total ${ }^{3}$ & $\mathrm{n} / \mathrm{a}$ \\
\hline
\end{tabular}

Several decision rules were used to determine technically removable residue quantities for corn, small grains, rice, and hay-alfalfa. The differences in decision rules reflected the different nature of the crops. For corn, 2 dry tons of residue per acre were deducted from total corn stover production (Table 6). For small grains and hay-alfalfa, the residue quantity was the product of the technically removable quantity of crop residue (a proportion of total residue) and residue per unit crop yield shown in Table 6.

The constraint used to determine technically removable corn quantities was more rigid than other crops because of the large geographic distribution and high erosion potential for corn crops. Small grain crops, including wheat, sorghum, oats, rye/barley, rice, and alfalfa, typically leave a smaller quantity of straw per acre than corn or hay. The rule of leaving 2 dry tons of residues per acre was relaxed for small grains to increase the potential to identify candidate states for feedstock availability. For this study, hay-alfalfa was considered a dedicated energy crop for which all production and harvesting costs are covered by the sale of hay-alfalfa as an ethanol feedstock. Therefore, a larger proportion of hay-alfalfa crops was assumed to be technically removable (60\% of total production). Hay yields reported by the USDA already reflect 
yields after harvest losses (USDA NASS November 1996). Assuming harvest losses of $10 \%$ and a deduction of $40 \%$ of the harvestable yield, about $50 \%$ of the above-ground biomass is left for soil conservation.

A decision rule was used to identify economically available corn, small grain, and rice crop residues. If the quantity of residues in the field was greater than 1 dry ton per acre after 2 dry tons were deducted from total residue production, the difference was considered available for use as an ethanol feedstock (Table 6). Quantities that demonstrated technically removable yields less than 1 dry ton per acre were considered unavailable. Economically available crop residues are shown in availability maps for each crop.

Estimated residue market prices were based on the fixed and operating costs of equipment used and the opportunity costs of equipment and nutrients. This method of price projection follows efforts of renewable fuel price estimates by Walsh (1996). As described previously, fixed hourly costs for agricultural equipment include depreciation, interest, insurance, and housing. Equipment hourly operating costs include fuel, lubrication, repairs, and labor. Repair costs are based on accumulated hours of lifetime use (Lazarus 1997). Managerial costs were included also, equal to $5 \%$ of total labor costs (Walsh 1996). Residue cost estimation relied on methods and cost data from the University of Minnesota Cooperative Extension in St. Paul, Minnesota; Nebraska State Cooperative Extension in Lincoln, Nebraska; and the Iowa State Cooperative Extension Service in Ames, Iowa (Lazarus 1997; Perry 1984; Ayres and Williams 1983).

A North Dakota State University compilation of equipment configurations used for harvesting crop residues supplied the basic equipment configuration assumed for cost estimation (WRBEP 1994).The basic equipment complement included a tractor drawn swather, large round balers, and bale wagons. The machinery complement represented standard farm equipment readily available and owned by farmers. University of Minnesota Department of Applied Economics and Iowa State University Cooperative Extension publications provided detailed equipment operating specifications (Lazarus 1997; Ayres and Williams 1983). Appendix B lists equipment configurations and operating variables in detail.

EFC is a measure of the land area that can be harvested per hour (acres/h). EFC accounts for the failure to fully use machine width, idle machine time, operator rest time, and other factors in field operations using equipment speed and efficiency data (Ayres and Williams 1983). EFC is a function of machine speed and efficiency, which were calculated for residue collection equipment using a relationship derived from Walsh (1996) that takes into account the effects of crop yield. Equipment operating characteristics that remain constant with crop yields include machine operating width, machine horsepower, fuel rate, equipment purchase price, productive machine time, hourly operating costs, and hourly total costs. The inverse of the EFC (h/acre) multiplied by the hourly total cost of equipment operation $(\$ / h)$ gives equipment total cost per acre of cropland (\$/acre). This value divided by the residue yield per acre (dry tons/acre) provided operating costs per dry ton ( $\$ /$ dry ton).

Opportunity costs of equipment operation and fertilizer value of residues removed were added to obtain the farmgate price per dry ton. Opportunity cost calculations were based on previous efforts by Walsh (1996). Opportunity costs of nutrients removed from cropland by residue collection were not included in price projections by Walsh (1996). To account for these costs explicitly estimated values of nutrients removed from cropland via residue collection were added (Table 7).

For hay-alfalfa crops, average costs for interest on land and improvements from the USDA NASS were included as input costs for feedstock production (USDA NASS 1997). Average seed, fertilizer, and agricultural chemical costs were incorporated into hay-alfalfa feedstock costs because this is a dedicated bioenergy crop. USDA NASS statistics provided state costs on average land and improvements, seed, agricultural chemicals, and fertilizer (USDA NASS 1997). 
Table 7.1996 crop residue nutrient values (\$/dry ton of residue)

\begin{tabular}{|c|c|}
\hline 2.109 & Sost: \\
\hline Corn & $\$ 5.33$ \\
\hline Wheat & $\$ 3.59$ \\
\hline Grain sorghum & $\$ 4.41$ \\
\hline Oats & $\$ 4.29$ \\
\hline Rye/Barley & $\$ 2.43$ \\
\hline Rice & $\$ 3.36$ \\
\hline
\end{tabular}

Source: WRBEP (1991)

\section{Results and Discussion}

Crop residue quantity, availability, and price estimation on this scale incorporate a degree of uncertainty because of geographic differences in crop and residue yields and costs. Crop yield estimates are based on random field sampling procedures on land, which represent about $1 \%$ of the total area in the United States. Cropland acreage is determined by in-person interviews with a sample of farmers at their farms (USDA NASS 1996). Residue quantity estimates predicated on crop harvest/yield data are thus subject to the same degree of error as are USDA yield and acreage estimates, as well as that associated with the variability of residue yield/unit of crop yield.

Crop residue prices are represented in this study by the sum of equipment fixed costs; variable costs; and opportunity costs of the use of labor, machinery, and nutrients employed. This estimate of the cost of production is a proxy for residue prices in the absence of established crop residue markets. As discussed previously, this estimate does not include risk premiums for residue generators to enter this new enterprise. Any new ethanol production process should evaluate the price farmers are willing to accept for residues as a temporary incentive to encourage a stable feedstock supply. This type of evaluation must be done on a local scale. Alternative methods of representing the opportunity costs of residues, incorporated into current price estimates using nutrient value of residues removed, could have included the use of residues as cattle fodder. The primary competing use for field crop residues is animal fodder. Factors affecting corn stover use for fodder include season (most is done in late fall and winter), location of fields in relation to cattle, lack of animal shelter or fencing, and animal water availability (Rasby and Selley 1992). It is assumed that farmers would not permit cattle to graze the residues if the nutrient value of the residue removed were greater than the feed value of the fodder. Thus, the fertilizer value is a proxy for the minimum feed value of field crop residues in the current study. Price estimates represent a competitive value for residues not used for feed and residues used in relatively low value feed operations.

Data on crop acres grazed following harvest are not readily available, so the quantities used for animal fodder are not well established. Even less readily available are distinctions between feed quality that would further allow the determination of low value quantities potentially available for ethanol production. The economically available residue quantities in the current study may be overestimated because of the use of residue in high-value feed applications. The magnitude of this error depends on the amount of crop residues used for feed. Further study should make these distinctions to better represent ethanol production potential from crop residues. 
Farm sizes vary extensively from state to state. Machinery complements do not incorporate changes in field size on residue collection costs. The resulting cost estimates, however, are conservative estimates of residue harvesting costs, because the machinery used is small enough to be used on smaller farms. Representing all possible harvesting equipment variations that could be used for residue harvesting is not the object of this study. Crop profitability affects the acreage planted for individual crops, and will affect annual residue availability (WRBEP 1991). This is not reflected in the estimates presented in this study, although crop variation over time should be further investigated in regional or facility siting studies.

\section{Corn Stover}

Corn stover consists of corn husks, leaves, cobs, and stalks left over in the field following harvest (NREL 1993). Table 8 shows a range of values for the composition of the above-ground biomass of the corn plant. The weight makeup of corn is variable, but it is beyond the scope of this study to account for all differences crop strain and yield may have on residue yield. Therefore, we assumed that there is 1:1 production (by weight) of corn stover and corn grain (WRBEP 1991).

Table 8. Weight makeup of the corn plant

\begin{tabular}{|c|c|}
\hline Plant Prot & gercenthlaleur \\
\hline Leaves & $5 \%-25 \%$ \\
\hline Grain & $20 \%-50 \%$ \\
\hline Cob & $6 \%-10 \%$ \\
\hline Husks & $6 \%-8 \%$ \\
\hline Stalk & $17 \%-40 \%$ \\
\hline
\end{tabular}

Source: Mahanna et al. (1996)

Table 9 shows 1996 corn stover quantity, availability, and price. The largest producers were Iowa, Illinois, Nebraska, and Minnesota. Figures 3 and 4 graphically show the distribution of U.S. corn stover quantity and economic availability in 1996.

Corn stover is the largest source of agricultural residue in the United States. Because corn is a high biomass yield crop, the corresponding residue yield is high as well. Therefore, corn stover availability is constrained in only a few states by the minimum of 1 ton per acre used for determining economic availability.

Corn stover prices in Table 9 are higher costs reported by Jose and Brown (1996). After incorporating nutrient costs of $\$ 14.12 /$ ton, they reported total costs of $\$ 23.97 /$ dry ton. There is a large discrepancy between nutrient values reported in WRBEP (1991) and Jose and Brown (1996). Corn stover nutrient values, $\$ 5.33 /$ dry ton, taken from WRBEP (1991) were adjusted for 3\% annual inflation to 1996 (Table 7). In the WRBEP (1991) effort, residue values were estimated based on the chemical composition of the residue and market values of chemical fertilizers used to replace lost nutrients. The lower value in this case was used because the cost estimation method was consistent with that used for other agricultural residue nutrient values in the study.

Corn stover availability (shown numerically in Table 9 and in map format in Figure 3 ) is numerically very similar to total corn stover production. Only corn that is grown for grain is included as a potential residue 
source. Silage corn, or corn and stover grown expressly for feed, are not incorporated into stover quantity or availability estimates.

\section{Small Grain Straw}

For this study, small grains were assumed to refer to oats, barley, rye, wheat, and sorghum. Wheat makes up the single largest single component of small grain straw; sorghum grain the next largest (Table 10). The residues considered are materials such as leaves, stalks, and chaff.

Table 11 gives estimated small grain straw quantity, availability, and price data for each state. Small grain crops are widely distributed across the United States, with coverage gaps in several New England states and Florida (Table 11). Most small grain production is concentrated in the Midwest. North Dakota, Nebraska, Minnesota, Kansas, and Texas figure prominently as large producers (Figure 6). Rye and sorghum have the largest distribution of the small grains.

As no states met the criteria of having more than 1 dry ton per acre left on the field after deductions from. total residue production for soil conservation, grain straw was considered unavailable as an ethanol feedstock. Rather than the 2 dry tons per acre required for soil conservation subtracted from total corn stover production to arrive at removable corn stover, a proportion equal to $65 \%$ of total above-ground residue produced was removed for soil conservation purposes (Table 6). No residue was available even with the more flexible assumption regarding the proportion of residue required for soil conservation used for small grain straw.

Small grain straw is either tilled in the soil or grazed by cattle (Fox 1987). Oat straw is often grazed because of its high protein content and hence high feed value (Fox 1987). Sorghum is often grown exclusively as a silage crop, although crop areas devoted to silage production are not incorporated into residue quantity estimates. USDA NASS statistics distinguish between sorghum grain and sorghum silage, allowing this distinction to be made. Low residue yields make small grains unlikely to play a large part as a feedstock for ethanol production. Because small grain straw has a negligible market, it is likely that little interstate traffic of small grain straw takes place. This is consistent with the absence of prices for small grain straw in non-producer states (Table 11).

A particular case scenario for which grain residues may be a suitable feedstock for ethanol production may be acreages devoted to seed production. In these areas, biomass accumulation is usually managed by open field burning. However, in regions of Nevada, Oregon, and other western states, air quality problems in areas of growing populations have made open field burning impracticable (Frolich 1996). In these areas, on-site or nearby ethanol production capacity could be a viable alternative to other disposal methods. The feasibility of such an operation would have to be evaluated case-by-case. 
Table 9. 1996 corn stover quantity, availability, and price estimates

\begin{tabular}{|c|c|c|c|c|c|c|c|}
\hline State & 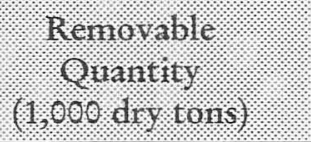 & ( & 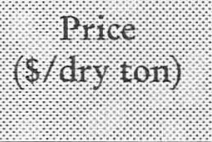 & State & 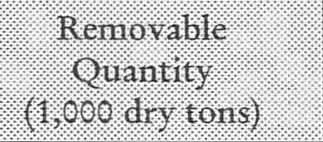 & , & (א. \\
\hline $\mathrm{AL}$ & 82.9 & $\ldots$ & - & $\mathrm{NC}$ & 594.0 & - & - \\
\hline AR & 747.5 & 747.5 & $\$ 25.42$ & $\mathrm{ND}$ & 394.6 & $\ldots$ & - \\
\hline $\mathrm{AZ}$ & 214.0 & 214.0 & $\$ 21.42$ & $\mathrm{NE}$ & $33,249.8$ & $33,249.8$ & $\$ 23.23$ \\
\hline $\mathrm{CA}$ & $1,038,4$ & $1,038.4$ & $\$ 22.03$ & $\mathrm{NH}$ & -- & -- & - \\
\hline $\mathrm{CO}$ & $3,726.2$ & $3,726.2$ & $\$ 23.33$ & $\mathrm{NJ}$ & 309.4 & 309.4 & $\$ 25.27$ \\
\hline $\mathrm{CT}$ & - & -- & -- & NM & 449.4 & 449.4 & $\$ 21.42$ \\
\hline $\mathrm{DE}$ & 600.9 & 600.9 & $\$ 23.23$ & NV & - & -- & - \\
\hline $\mathrm{FL}$ & 52.0 & -- & - & $\mathrm{NY}$ & $1,571.2$ & $1,571.2$ & $\$ 29.30$ \\
\hline GA & 346.5 & - & - & $\mathrm{OH}$ & $7,320.5$ & $7,320.5$ & $\$ 28.22$ \\
\hline IA & $47,260.2$ & $47,260.2$ & $\$ 23.73$ & $\mathrm{OK}$ & 695.3 & 695.3 & $\$ 23.06$ \\
\hline ID & 146.8 & 146.8 & $\$ 24.06$ & OR & 162.7 & 162.7 & $\$ 21.79$ \\
\hline II & 40.089 .6 & $40,089.6$ & $\$ 23.95$ & PA & 3.207 .9 & $3,207.9$ & $\$ 26.47$ \\
\hline IN & 17.254 .7 & 7.254 .7 & $\$ 25.75$ & $\mathrm{RI}$ & - & -- & -- \\
\hline $\mathrm{KS}$ & 10.302 .4 & 10.302 .4 & $\$ 22.52$ & $\mathrm{SC}$ & - & - & - \\
\hline $\mathrm{KY}$ & 3.849 .6 & 3.849 .6 & $\$ 25.58$ & $\mathrm{SD}$ & $8,140.0$ & $8,140.0$ & $\$ 31.63$ \\
\hline IA & 1.699 .8 & 1.699 .8 & $\$ 25.42$ & TN & 1.953 .0 & $1,953.0$ & $\$ 27.07$ \\
\hline MA & -- & -- & -- & TX & $4,867,2$ & $4,867.2$ & $\$ 27.98$ \\
\hline $\mathrm{MD}$ & 1.784 .7 & 1.784 .7 & $\$ 23.62$ & UT & 72.7 & 72.7 & $\$ 24.69$ \\
\hline $\mathrm{ME}$ & $\ldots$ & $\ldots$ & - & $\mathrm{VA}$ & $1,020.5$ & $1,020.5$ & $\$ 25.27$ \\
\hline $\mathrm{MI}$ & $1,453.6$ & -- & $\ldots$ & $\mathrm{VT}$ & $\ldots$ & $\ldots$ & - \\
\hline $\mathrm{MN}$ & $22,587.5$ & $22,587.5$ & $\$ 25.42$ & WA & -- & $\ldots$ & - \\
\hline $\mathrm{MO}$ & $9,614.2$ & $9,614.2$ & $\$ 24.18$ & WI & $7,986.0$ & $7,986.0$ & $\$ 28.22$ \\
\hline MS & $1,381.8$ & $1,381.8$ & $\$ 30.90$ & WV & 96.4 & 96.4 & $\$ 29: 90$ \\
\hline $\mathrm{MT}$ & 56.3 & 56.3 & $\$ 23.84$ & WY & 158.3 & 158.3 & $\$ 25.75$ \\
\hline & & & \multicolumn{2}{|c|}{ Total/Average } & $236,538.5$ & $233,614.9$ & $\$ 25.26$ \\
\hline
\end{tabular}




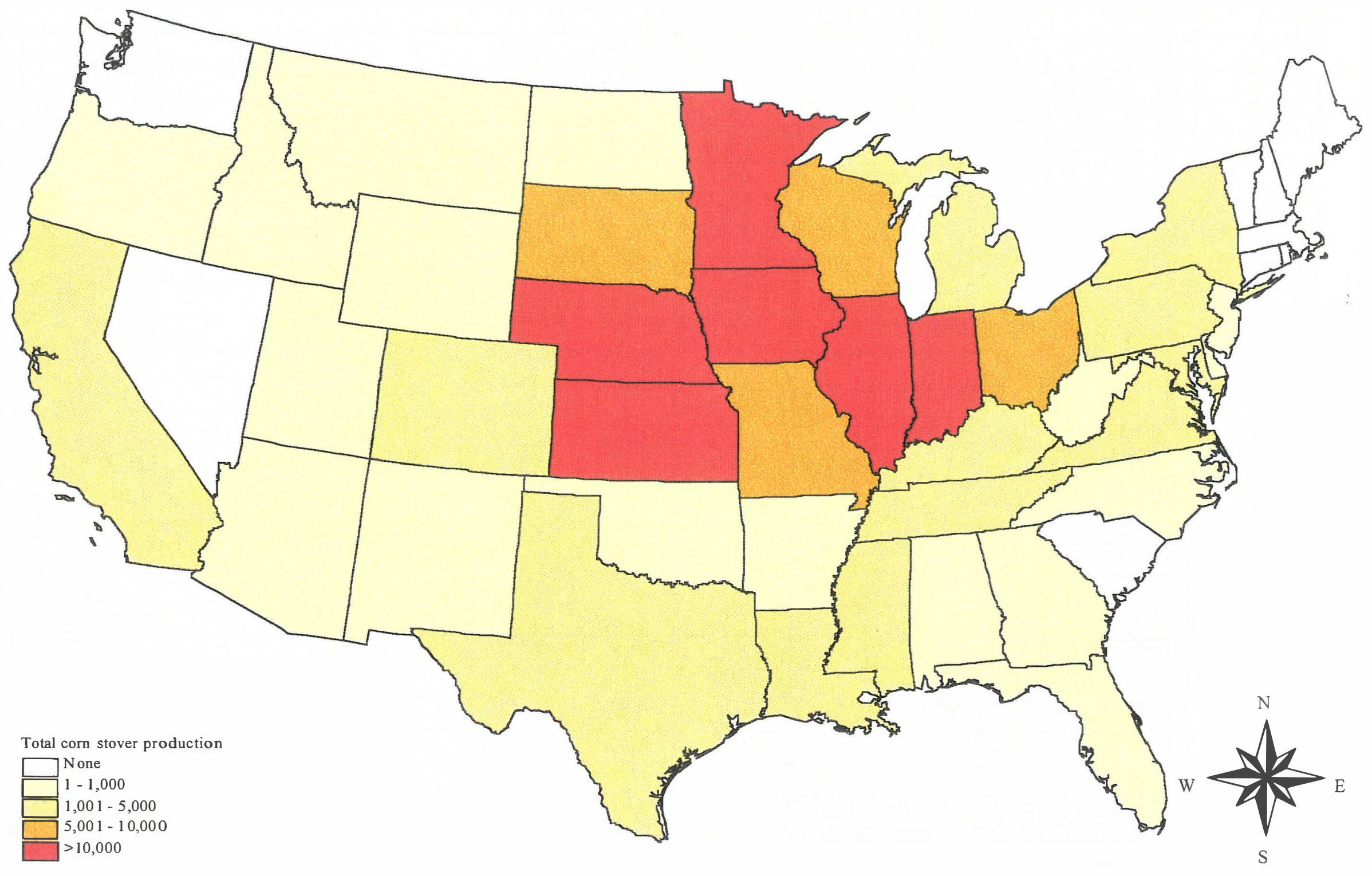

Figure 4. Total corn stover production in 1996 (thousand dry tons/year) 


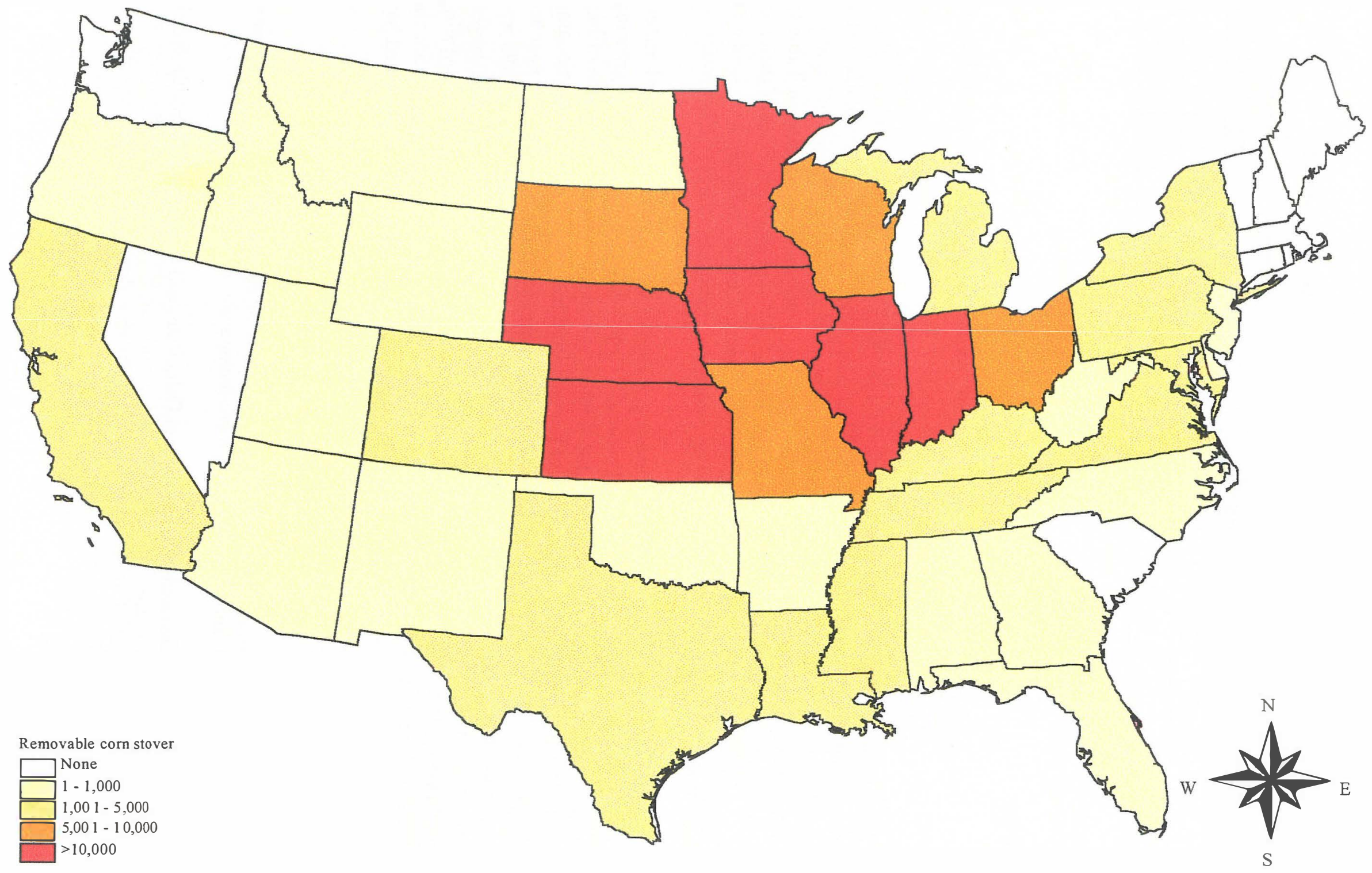

Figure 5. Available corn stover in 1996 (thousand dry tons/year) 
Table 10. Quantity and percent of total small grain production by crop component

\begin{tabular}{|c|c|c|c|c|c|c|}
\hline (1. & Wilieat & 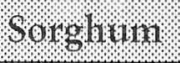 & Barley. & Oats. & roe & Toral \\
\hline Quantity (1,000 dry tons) & $11,838.9$ & $6,603.5$ & $3,263.1$ & $1,275.2$ & 73.2 & $23,049.5$ \\
\hline Percent (\%) & $51.3 \%$ & $28.6 \%$ & $14.2 \%$ & $5.5 \%$ & $0.3 \%$ & $99.9 \%$ \\
\hline
\end{tabular}

Source: Quantities calculated based on acreage and yield data from USDA NASS (1997).

Note: Percentages add up to $99.9 \%$ due to rounding error.

\section{Grass Straw}

We assumed that grass straw refers to hay-alfalfa straw, which we consider to be a dedicated energy crop.

Quantity and availability data are included in Table 12. Hay-alfalfa straw is grown in most of the United States except for a cluster of states in the Southeast. The quantity of hay-alfalfa straw produced for the various states is shown in Figure 8, along with available quantities in Figure 9. Available quantities represent $60 \%$ of the harvestable portion of biomass as specified in Table 6. This proportion is larger than that for small grain straw because the primary purpose of the crop in this case is ethanol feedstock produc- tion. Agricultural chemical costs, and interest on land and capital are included in hay-alfalfa costs, whereas these costs are not factored in for crop residues.

Hay-alfalfa straw is used for animal feed and bedding materials throughout the United States. Overall, U.S. hay-alfalfa prices have increased steadily, largely because of a steadily growing export market. Estimated prices for hay-alfalfa for 1996 are given in Table 12. The value of hay has increased $800 \%$ since 1985 , and the quantity of hay exported increased $700 \%$ during the same period (Morgan 1997). Time series data on U.S. hay price indexes using 1900 as the base year are shown graphically in Figure 7. The largest importer of hay from the United States in 1996 was Japan ( $94 \%$ of all imports from the United States); Taiwan and Korea are the next largest importers (Morgan 1997). Demand has increased in these countries because of a growing consumer demand for animal proteins (Morgan 1997). Hay-alfalfa export composition from the United States has changed as well. Alfalfa cube and meal export markets have declined; baled hay markets abroad have increased in size and value (Morgan 1997).

\section{Rice Straw}

Rice straw residues refer to leaves and stalks remaining in the field after harvest. Table 13 shows estimated rice straw quantity, availability, and price data for rice-producing states in the United States.

Rice production is heavily concentrated in the Mississippi Delta states and California (Figure 10). Nearly all rice straw produced is available, given the current lack of an outlet commodity market (Figure 11). Rice straw is used for animal feed, tilled into soil, or burned on-site after drying. More efficient collection methods may increase the feasibility of using rice straw as a feedstock for ethanol production. In California, air quality degradation from rice straw disposal is a production issue (IRRI 1997). 
Rice straw has a high moisture content at harvest ( $80 \%)$. This can substantially affect production costs depending on harvest time. A moisture content of $40 \%$ was assumed at the time of residue collection, which would require weeks or months before collection. Climatic conditions will affect the drying rate and collection costs. The climate for rice-growing areas in the United States varies from semiarid in California to subtropical in the Gulf Coast of Louisiana and Texas (IRRI 1997). In all areas of the United States, rice is grown as an annual crop. It is grown on flatlands, either natural or graded, and is irrigated and direct seeded.

U.S. rice consumption has doubled since 1972 because of health concerns and dietary preferences, but percapita consumption is still small compared to many Asian nations. U.S. total production accounts for less than $2 \%$ of world production, and covers only $0.7 \%$ of the cropped land area and less than $1 \%$ of the value of agricultural production in the United States (IRRI 1997). Despite the proportionally small size of rice relative to other grain U.S. crops, rice straw production of just under 3 million dry tons/year is enough to support ethanol production given favorable economics of collection. 


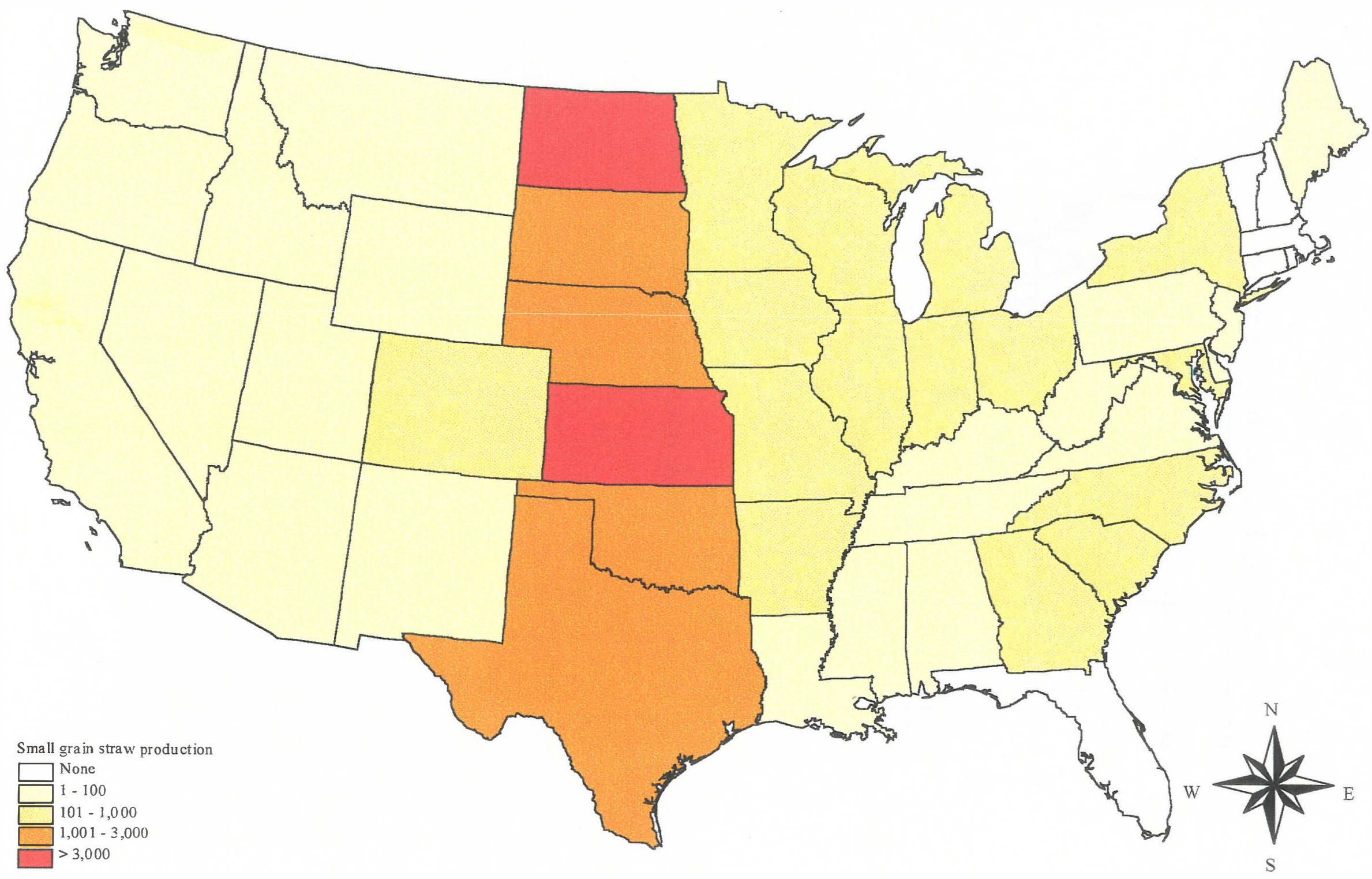

Figure 6. Total small grain straw production in 1996 (thousand dry tons/year) 


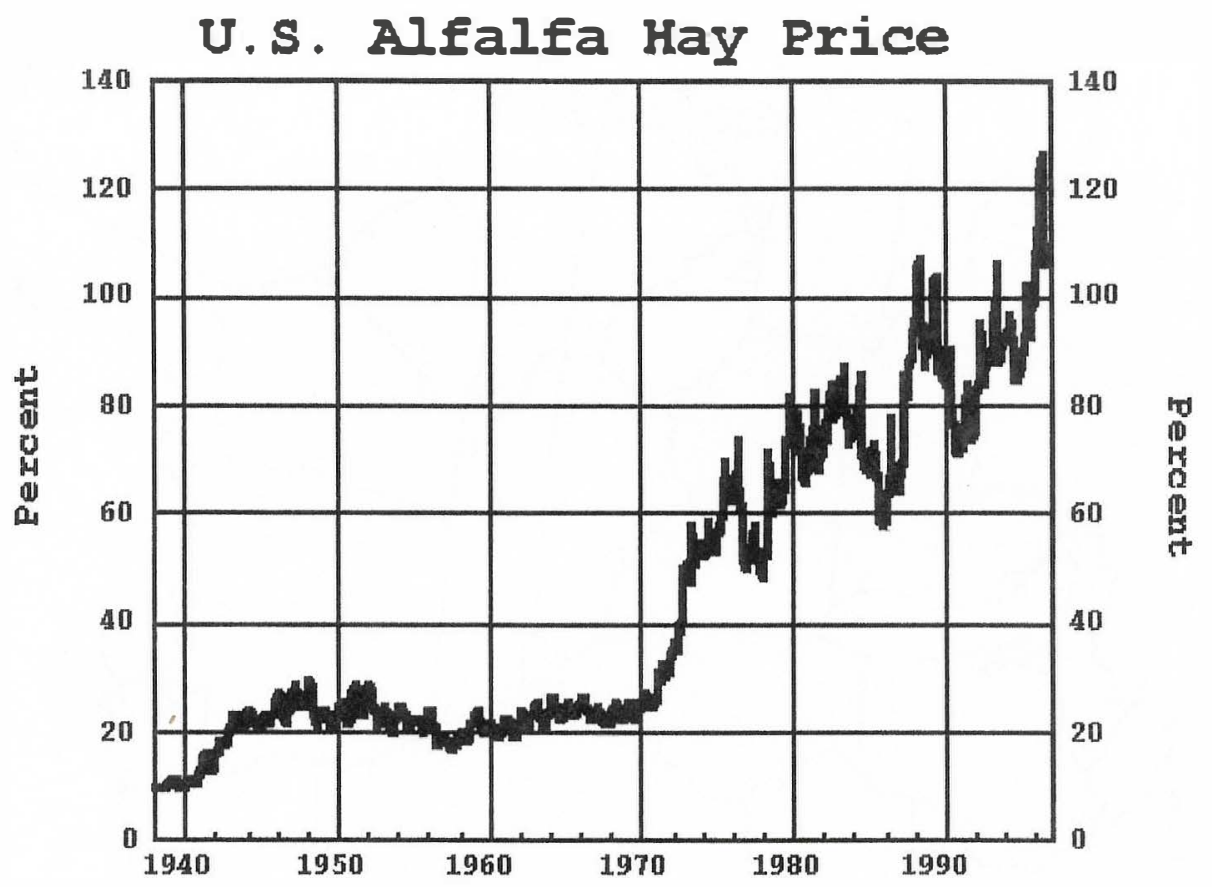

Figure 7. US hay price indices: 1939 to present (base year 1900) Source: Morgan (1997) 
Table 12. Hay-alfalfa straw quantity, availability, and price estimates

\begin{tabular}{|c|c|c|c|c|c|c|c|}
\hline Sitalex. & 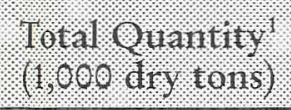 & 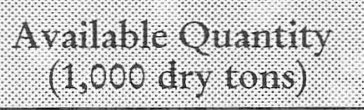 & 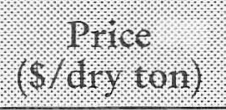 & State & $(1,000$ (1) & 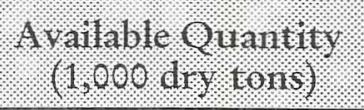 & 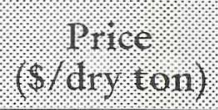 \\
\hline $\mathrm{AL}$ & - & -- & - & $\mathrm{NC}$ & 27.0 & 16.2 & $\$ 32.58$ \\
\hline $\mathrm{AR}$ & 30.0 & 18.0 & $\$ 89.44$ & $\mathrm{ND}$ & $2,040.0$ & $1,224.0$ & $\$ 129.00$ \\
\hline $\mathrm{AZ}$ & 768.0 & 460.8 & $\$ 30.18$ & $\mathrm{NE}$ & $3,360.0$ & $2,016.0$ & $\$ 30.64$ \\
\hline $\mathrm{CA}$ & 3,948 & $2,368.8$ & $\$ 19.42$ & $\mathrm{NH}$ & 14.4 & 8.6 & $\$ 63.18$ \\
\hline $\mathrm{CO}$ & 2,064 & $1,238.4$ & $\$ 81.41$ & NT & 60.0 & 36.0 & $\$ 95.81$ \\
\hline $\mathrm{CT}$ & 18.0 & 10.8 & $\$ 53.49$ & NM & 765.0 & 459.0 & $\$ 194.51$ \\
\hline $\mathrm{DE}$ & 21.0 & 12.6 & $\$ 165.41$ & NV & 576.0 & 345.6 & $\$ 22.29$ \\
\hline $\mathrm{FL}$ & - & - & -- & NY & $1,152.0$ & 691.2 & $\$ 30.00$ \\
\hline GA & -- & -- & - & $\mathrm{OH}$ & $1,260.0$ & 756.0 & $\$ 76.42$ \\
\hline IA & $2,880.0$ & $1,728.0$ & $\$ 48.93$ & $\mathrm{OK}$ & 936.0 & 561.6 & $\$ 72.74$ \\
\hline ID & $2,400.0$ & $1,440.0$ & $\$ 57.51$ & OR & $1,104.0$ & 662.4 & $\$ 30.99$ \\
\hline IL & $1,440.0$ & 864.0 & $\$ 40.62$ & $\mathrm{PA}$ & $1,350.0$ & 810.0 & $\$ 52.09$ \\
\hline IN & 765.0 & 459.0 & $\$ 97.30$ & $\mathrm{RI}$ & 3.6 & 2.2 & $\$ 114.38$ \\
\hline $\mathrm{KS}$ & $1,920.0$ & $1,152.0$ & $\$ 66.67$ & $\mathrm{SC}$ & -- & -- & - \\
\hline $\mathrm{KY}$ & 720.0 & 432.0 & $\$ 31.27$ & $\mathrm{SD}$ & $3,000.0$ & $1,800.0$ & $\$ 91.07$ \\
\hline LA & -- & - & - & TN & 72.0 & 43.2 & $\$ 34.97$ \\
\hline MA & 18.0 & 10.8 & $\$ 79.96$ & TX & 360.0 & 216.0 & $\$ 57.82$ \\
\hline $\mathrm{MD}$ & 180.0 & 108.0 & $\$ 140.76$ & $\mathrm{UT}$ & $1,308.0$ & 784.8 & $\$ 31.94$ \\
\hline $\mathrm{ME}$ & 18.0 & 10.8 & $\$ 152.30$ & VA & 312.0 & 187.2 & $\$ 34.63$ \\
\hline MI & $2,280.0$ & $1,368.0$ & $\$ 54.98$ & VT & 78.0 & 46.8 & $\$ 126.08$ \\
\hline $\mathrm{MN}$ & $2,655.0$ & $1,593.0$ & $\$ 78.14$ & WA & $1,470.0$ & 882.0 & $\$ 55.44$ \\
\hline $\mathrm{MO}$ & 864.0 & 518.4 & $\$ 56.94$ & WI & $2,520.0$ & $1,512.0$ & $\$ 83.39$ \\
\hline MS & - & - & -- & WV & 72.0 & 43.2 & $\$ 73.02$ \\
\hline MT & $2,040.00$ & $1,224.0$ & $\$ 66.85$ & WY & 744.0 & 446.4 & $\$ 73.51$ \\
\hline & & & \multicolumn{2}{|c|}{ Total/Average } & $47,613.0$ & $28,567.8$ & $\$ 65.21$ \\
\hline
\end{tabular}

Source: USDA NASS (1997) 


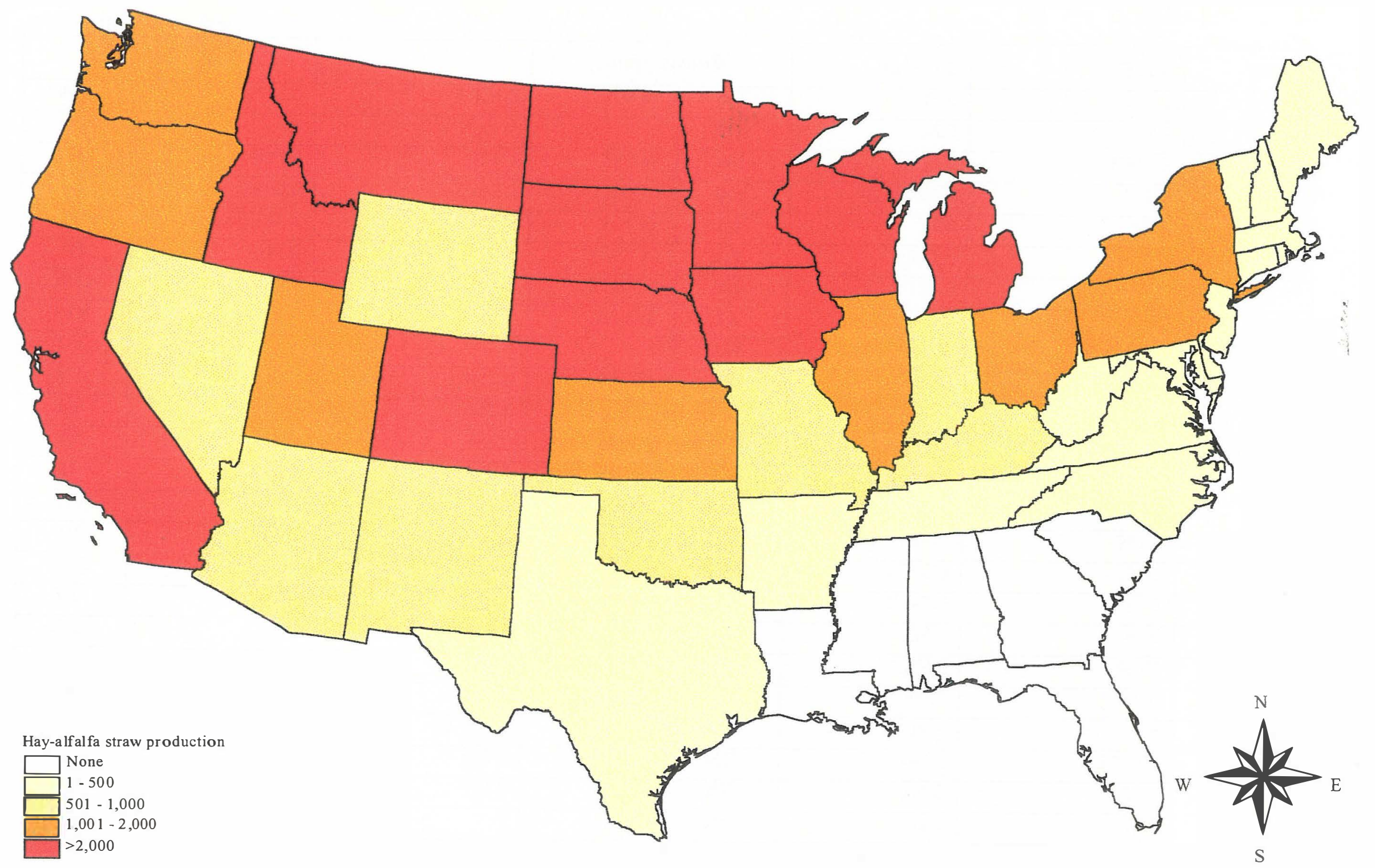

Figure 8. Total hay-alfalfa straw production in 1996 (thousand dry tons/year) 


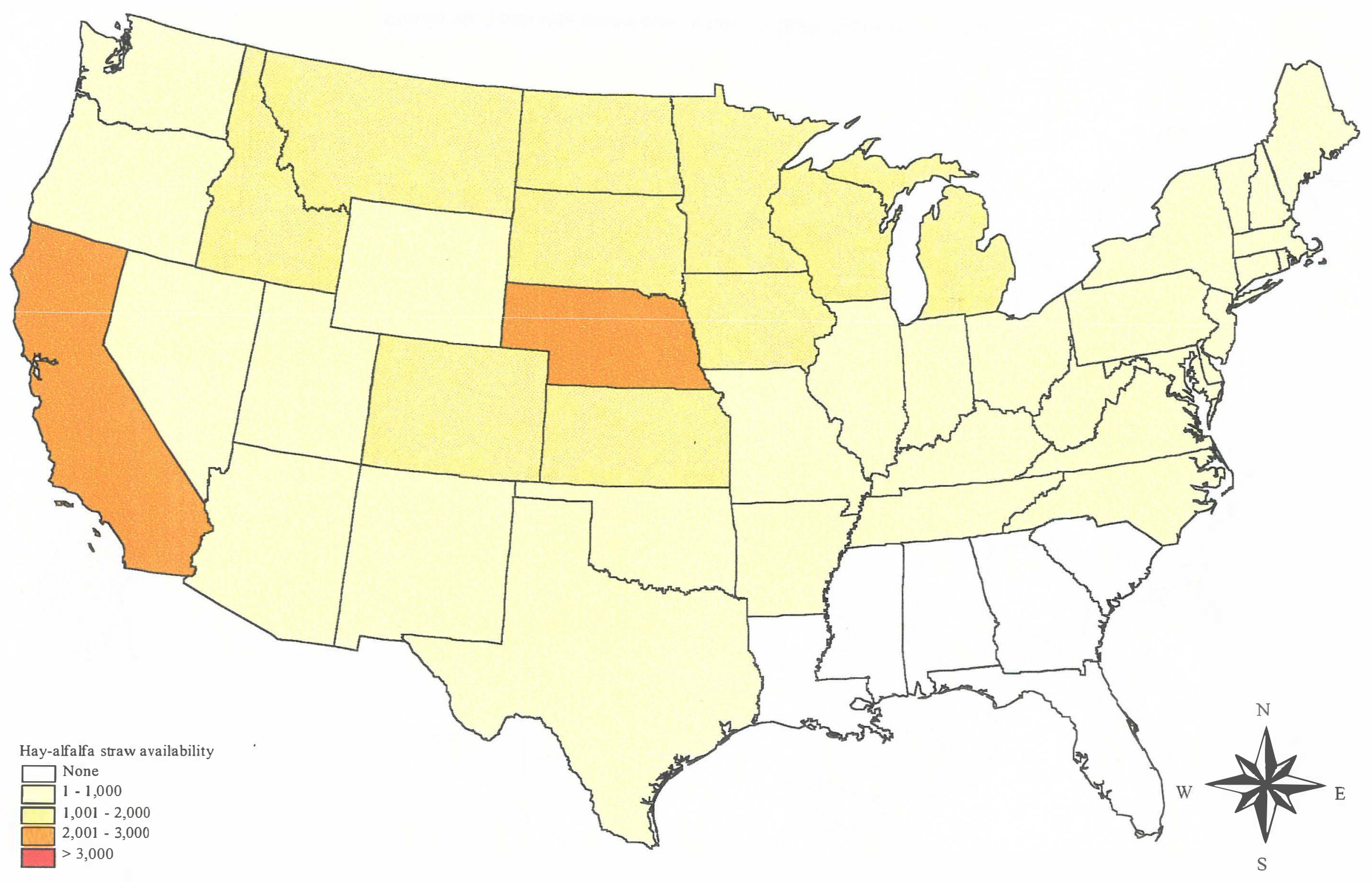

Figure 9. Available hay-alfalfa straw in 1996 (thousand dry tons/year) 


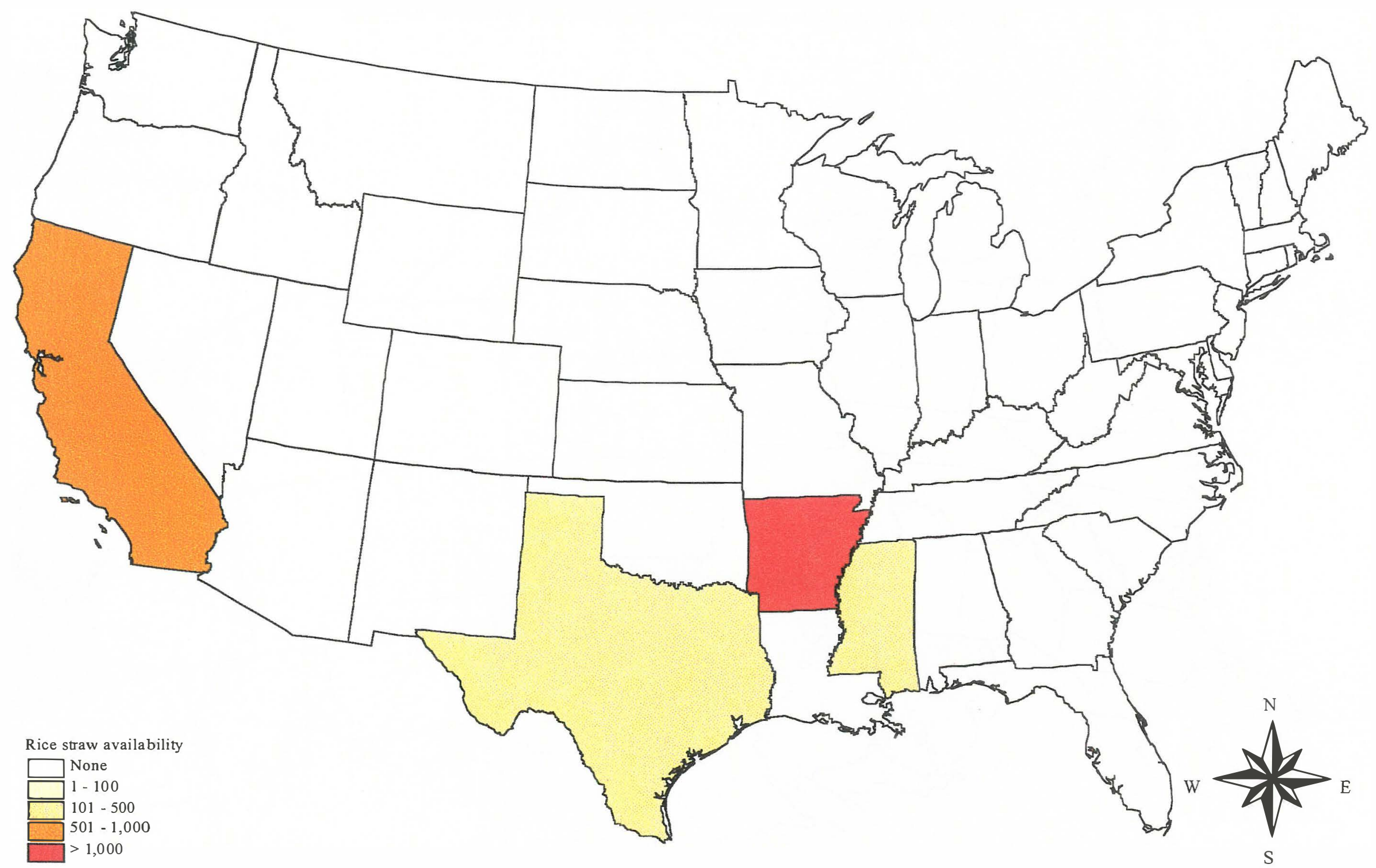

Figure 10. Total rice straw production in 1996 (thousand dry tons) 


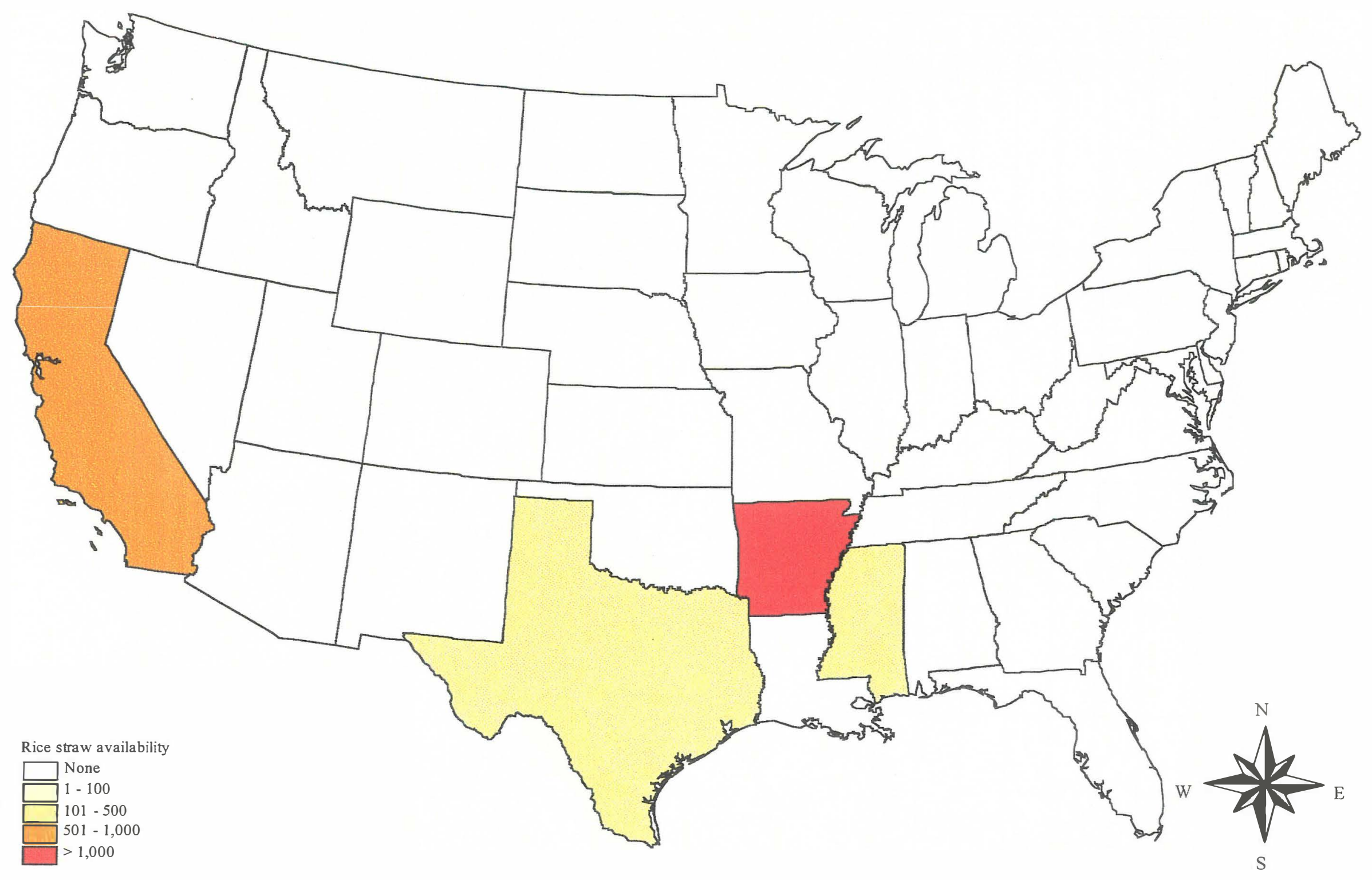

Figure 11. Available rice straw in 1996 (thousand dry tons) 
Table 13. Rice straw quantity, availability, and price estimates

\begin{tabular}{|c|c|c|c|}
\hline Srater. & 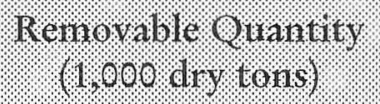 & 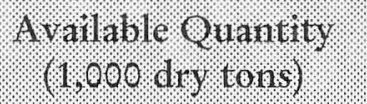 & ( \\
\hline $\mathrm{AR}$ & $1,257.8$ & $1,257.8$ & $\$ 32.68$ \\
\hline $\mathrm{CA}$ & 872.5 & 872.5 & $\$ 22.84$ \\
\hline LA & 231.9 & - & $\$ 69.59$ \\
\hline MO & 69.8 & - & $\$ 70.67$ \\
\hline MS & 208.0 & 208.0 & $\$ 33.16$ \\
\hline $\mathrm{TX}$ & 327.8 & 327.8 & $\$ 30.62$ \\
\hline Total/Average & $2,967.8$ & $2,666.1$ & $\$ 43.06$ \\
\hline
\end{tabular}




\section{Forest Products Industry Residues}

This section describes the quantity, availability, and market value for residues from primary and secondary forest products industries. Primary mill residue quantity data are derived from USDA Forest Service residue survey information and EIA data. For secondary mill residues, quantities are estimates based on industrial production capacity data. Price information for primary and secondary mill residues reflect a range of prices to account for differences in the form and quality of residues. There are established markets for mill residues, so available mill residue data show quantities for which price may be a factor in persuading producers to choose alternative outlet (non-captive) markets.

Forest products industry residues (both hardwood and softwood) consist of woody slabs, edgings, cants, ends, bark, sawdust, and planer shavings associated with milling. Residue data will be categorized in this study as coarse and fine to match data conventions used by price reporting industry associations. Coarse residues consist of slabs, edgings, cants, and ends. Fine residues include shavings, sawdust, and bark.

Primary hardwood residues are produced by forest products establishments that use unprocessed logs as part their raw materials. Such establishments include sawmills and planing mills described by the U.S. Office of Management and Budget SIC Classification 2421, under the Sawmill and Planing Mills Industry Group and Major Group Sawmills and Planing Mills. These organizations produce cants; chips; rough, dressed, kiln-dried, resawn, and softwood veneer stock; fuel wood from mill waste; softwood furniture dimension stock; siding; silo stock; fence lath; studs; railroad ties; and tobacco hogshead stock.

Secondary residues are produced in operations that typically do not use unprocessed logs as raw material, such as kitchen cabinet operations, custom millwork, and wood structural member production. SIC codes included in this residue source fall within Industry Groups Sawmills and Planing Mills; Millwork, Veneer, Plywood, and Structural Wood Members, and Household Furniture, including codes 2426-2499, and 2511-2519.

\section{Data Sources and Methodology}

\section{Primary Mill Residues}

EIA assembled primary mill hardwood and softwood residue quantity and price information for its wood fuel cost/supply schedule, a submodule of the renewable fuels module for the National Energy Modeling System (NEMS) (Decision Analysis Corporation of Virginia 1995). EIA acquired information from the USDA Forest Service, which performs a complete survey of primary mills approximately every 10 years and an update every 5 years as part of its responsibility for the 1974 Resources Planning Act (RPA) (P.L. 93-378, 88 Statute 4765) Forest and Rangeland Renewable Resources Assessment (Smith et al. 1994). The latest RPA update was completed and published in 1994. Reporting regions for the Forest Service are shown in Figure 12. The reporting regions differ from the administrative regions for the Forest Service, more closely delineating physical and ecological boundaries that define the forest resources of the United States. Individual states collect mill data, which are accumulated regionally and nationally.

Forest Service residue data represented different data years for different states. All data gathered after January 1, 1989 and included in the 1994 RPA update were considered current (Smith et al. 1994). Data assembled before 1989 were updated in the 1994 report to more closely represent industry conditions between 1989 and 1994. These data were not collected expressly for the 1994 RPA update. Update procedures vary by reporting region (Smith et al. 1994). Table 14 shows the dates for state surveys. The dates shown in Table 14 indicate the years data were collected for quantities in the 1994 RPA update. 


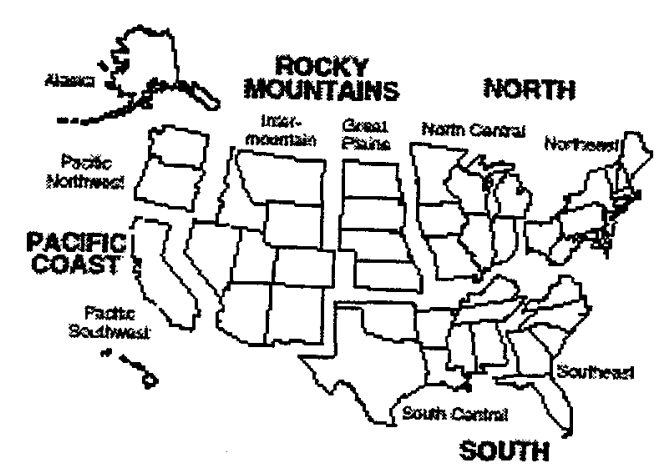

Figure 12. USDA Forest Service data reporting regions

Table 14. Publication dates for state primary mill residue data

\begin{tabular}{|c|c|c|}
\hline Bate & Irequerey: & states. \\
\hline 1982 & 1 & $\mathrm{CO}$ \\
\hline 1983 & 1 & WY \\
\hline 1984 & 1 & $\mathrm{AZ}$ \\
\hline 1985 & 0 & \\
\hline 1986 & 1 & NM \\
\hline 1987 & 2 & IL, WV \\
\hline 1988 & 4 & IA, MN, MT, PA \\
\hline 1989 & 2 & $\mathrm{NH}, \mathrm{VT}$ \\
\hline 1990 & 3 & ID, IN, NY \\
\hline 1991 & 10 & $\begin{array}{l}\text { AL, AR, FL, KY, LA, MO, MS, } \\
\text { OK, TN, TX }\end{array}$ \\
\hline 1992 & 9 & CA, GA, MI, NC, OH, OR, SC, UT, WI \\
\hline 1993 & 4 & KS, NE, ND, SD \\
\hline Total & 38 & \\
\hline
\end{tabular}

Note: States for which data were not updated from the 1987 report included AZ, CO, FL, D, MT, NE, NV, OR, SC, SD, VT, WA, WY. States for which publications were not identified included AL, CT, DE, MA, MD, ME, NV, RI, VA, and WA. NV did not have any primary mills at the time of the most recent survey.

Primary mill residue data for the 1997 RPA assessment should be forthcoming early in 1998, allowing a more current evaluation of residue availability for ethanol production.

Forest products industry residue prices were obtained from EIA data (Decision Analysis Corporation of Virginia 1995). EIA mill residue prices were based on information obtained from Timber Mart-South and 
Timber Mart-North for the following census division regions: East North Central, West North Central, South Atlantic, East South Central, and West South Central. Prices for the other census divisions were based on personal communications with state use and marketing foresters, utilities using wood fuel, sawmills, state energy offices, and trade associations. Because of lack of data, prices for the Pacific Census Division were extended to the Mountain Census Division, and prices for New England to the Middle Atlantic. Regional prices were extended to the state level, in the absence of published information on a finer scale.

Weighted average prices were calculated, taking into account the relative composition of coarse and fine bark residues in states. The low end of the price data range approximated fine and bark mill residue prices. The upper end of the Timber Mart-South range of prices approximated coarse mill residue prices. Prices were converted to $\$ /$ dry ton assuming a $50 \%$ moisture content (wet basis). Primary mill residue quantities were reported as fine, bark, or coarse, enabling weighted prices to be calculated for states.

\section{Secondary Mill Residues}

Industry and government agencies do not compile secondary mill residue data for most states. Several states, including Minnesota, recently gathered extensive data to identify residue production and use by the secondary forest products industry. Minnesota calculated average residue production volume by establishment by employee size class for the secondary forest products industry. These values, shown in Table 15, provided the basis for estimating state level secondary residue production for the conterminous states.

Table 15. Residue conversion factors for secondary forest products industry establishments

\begin{tabular}{|c|c|c|c|c|c|}
\hline 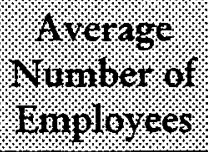 & 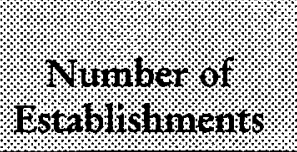 & 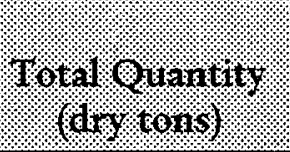 & 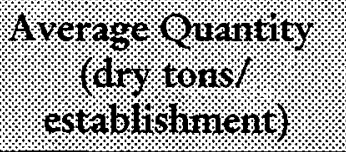 & 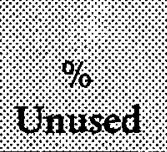 & 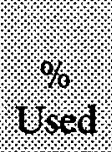 \\
\hline $1-10$ & 713 & 44,900 & 63 & $24 \%$ & $76 \%$ \\
\hline $10-19$ & 138 & 38,580 & 280 & $23 \%$ & $77 \%$ \\
\hline $20-49$ & 176 & 121,610 & 691 & $29 \%$ & $71 \%$ \\
\hline $50-99$ & 35 & 59,280 & 1,694 & $23 \%$ & $77 \%$ \\
\hline $100-499$ & 32 & 68,340 & 2,136 & $14 \%$ & $86 \%$ \\
\hline $500-999$ & 3 & 25,610 & 8,537 & $8 \%$ & $92 \%$ \\
\hline$>1,000$ & 3 & 108,460 & 36,153 & $5 \%$ & $95 \%$ \\
\hline Total & 1,100 & 466,870 & 424 & & \\
\hline
\end{tabular}

Source: Prosek et al. (1994)

The level of geographic specificity of DOC data is restricted because of the potential to divulge proprietary information. DOC can, however, provide the number of establishments by employee size class on a state level without compromising the confidentiality of industry respondents.

With the assistance of DOC staff, the number of establishments by SIC code by state was extracted from the 1992 Census of Manufacturers databases. These data were used to estimate the secondary mill residue 
production (Jamski 1997). Residue production was estimated by multiplying the number of secondary forest products establishments in employee size classes for each state by residue coefficients from the Minnesota Department of Natural Resources (Table 15).

Minnesota Department of Natural Resources data did not specify the hardwood/softwood composition of the residue mix. To do this, we multiplied the total secondary mill residue quantity by the percent hardwood and softwood makeup of primary mill residues from Forest Service data. We assumed that most materials for secondary mills in a given state come from that state or region. This assumption allowed us to develop estimates of hardwood and softwood secondary residue production.

Mill residues are considered available if they were currently unused, landfilled, or used in non-captive markets. Residues used for fiber are excluded as a feedstock because of their high value. Generally, coarse primary mill residue chips are used for fiber; a very small portion of secondary mill residues go to this end use. We assumed that $36 \%$ of all currently used mill residues are sold in non-captive markets. Further, we assumed that $50 \%$ of unused residues are available for energy uses, reflecting residue quality and recoverability (Turhollow et al. 1996).

To illustrate residue quality differences, landfilled or unused quantities are mapped separately from residues currently sold in non-captive markets. Unused residues may be generated by small companies or be of mixed quality. Unused residues are often available for a nominal (or negative) price to end users. Residue production from secondary establishments with fewer than 10 employees is often nominal, geographically diffuse, and of mixed quality.

Primary mill residue data sources distinguished between uses for mill residues and corresponding hardwood/softwood proportions, but estimates of competing uses had to be made for secondary mill residues. Table 16 shows the proportions used to calculate competing uses for secondary mill residues.

Table 16. Uses of secondary mill residue

\begin{tabular}{|c|c|}
\hline Obse & revarat \\
\hline Fuel sold/given & $27.3 \%$ \\
\hline Fuel used on site & $20.7 \%$ \\
\hline Animal bedding & $26.2 \%$ \\
\hline Mulch & $4.1 \%$ \\
\hline Paper/particleboard & $2.8 \%$ \\
\hline Other & $1.8 \%$ \\
\hline Landfilled/refuse hauled & $17.2 \%$ \\
\hline
\end{tabular}

Source: Prosek et al. (1994)

Prices for secondary forest products industry were estimated using the EIA data for primary mill residues, but assumed different proportions of coarse and fine residues. For secondary mill residues the proportion of coarse/fine residues used for calculations was assumed to be $63 \%$ coarse to $37 \%$ fines/bark (Prosek et al. 1994). 


\section{Results and Discussion}

This section breaks down residues into several categories of production and use. Primary and secondary forest products industries are the initial categories and are described in the introduction to the Forest Products Industry Residues section. Softwood and hardwood are as defined in Forest Service terminology. Residues are sold in non-captive markets as value added products but may be available at a competitive price for use as an ethanol feedstock. Recoverable unused or landfilled residues are often available at a reduced price or a fee may be charged to waste producers to accept them. Prices included in this report are valid only for residues that are currently sold. Unused but recoverable residues are assumed to be available for the net value of the deferred landfill tipping cost minus transportation costs.

Overall, the quantity of mill residues generated has increased over time, although lumber yield per unit of raw material has increased as well. The proportion of residues used in value-added products has also increased over time (Alerich and Drake 1994). Whether the total quantity of residues landfilled has increased over time is unclear. This determination would require a measurement of the rate of increase both of mill residue production and recovery. An estimate of this nature is unlikely to be reliable on a state level, given the quality and quantity of residue data available.

\section{Primary Mill Residues}

Primary hardwood mill residue production is concentrated in the eastern United States, the Lakes States, and the Mississippi Delta states (Figure 13). The most prominent producers include Kentucky, Maine, Ohio, and West Virginia (shown graphically in Figure 13; numeric quantity data are in Table 17). Although substantial interstate and international commerce involving hardwood sawlogs is conducted in the United States, the location of the bulk of hardwood primary processing residues is still concentrated near the forest resource that is the point of origin of the raw material. This is due to high sawlog transportation costs. Figure 14 shows the quantity of hardwood primary mill residues currently used in noncaptive markets by each state. Figure 15 depicts quantities of hardwood mill residues that are unused or landfilled but may be recovered for use as an ethanol feedstock. Residue use data are given in Table 17.

Softwood primary mill residue production is most prominent in the Southeast, the Mississippi Delta states, and the Pacific Northwest. Maine is also a large softwood producer because of the paper industry's prominence in its economy (Figure 16). Oregon, Washington, Maine, and Georgia are the largest residue producers.

Table 18 contains total quantities, prices, quantities sold in non-captive markets, and recoverable unused quantities of softwood primary mill residues. Figure 17 shows the quantity of softwood primary residues currently used in non-captive markets. Softwood residue chips are highly valuable as paper pulp feedstock and are not likely candidates for ethanol production. Figure 18 shows softwood primary residues that are unused or landfilled. Softwood residues are more readily used, in part because of their value for paper production and in part because of the greater ease of processing that result from uniform log shape and mechanical characteristics. 
Table 17 . Hardwood primary mill residue

\begin{tabular}{|c|c|c|c|c|c|c|c|c|c|}
\hline $814 t$ & (8.00\% & ( & 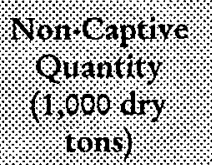 & (1) & State & Q & (1) & 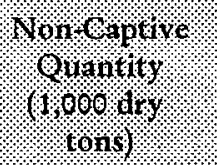 & 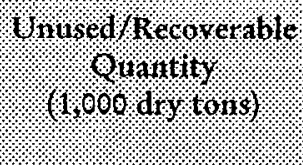 \\
\hline $\mathbf{A L}$ & $1,494.0$ & $\$ 20.00$ & 715.0 & 24.3 & $\mathrm{NC}$ & $1,801.0$ & $\$ 23.50$ & 872.0 & 21.7 \\
\hline $\mathrm{AR}$ & $1,490.0$ & $\$ 20.60$ & 715.5 & 22.4 & $\mathrm{ND}$ & 2.2 & $\$ 23.10$ & 0.9 & 0.2 \\
\hline $\mathrm{AZ}$ & _- & $\mathrm{n} / \mathrm{a}$ & $\mathrm{n} / \mathrm{a}$ & $\mathrm{n} / \mathrm{a}$ & NE & 31.0 & $\$ 19.60$ & 10.5 & 3.8 \\
\hline $\mathrm{CA}$ & 52.0 & $\$ 24.70$ & 26.0 & - & $\mathrm{NH}$ & 737.0 & $\$ 24.80$ & 344.0 & 18.6 \\
\hline $\mathrm{CO}$ & 23.0 & $\$ 25.10$ & 3.5 & 6.1 & NI & 44.0 & $\$ 25.40$ & 22.0 & $\ldots$ \\
\hline $\mathrm{C}^{\prime} \mathrm{T}$ & 157.0 & $\$ 24.60$ & 73.0 & 4.2 & NM & - & $\ldots$ & $\mathrm{n} / \mathrm{a}$ & $\mathrm{n} / \mathrm{a}$ \\
\hline DE & 39.0 & $\$ 23.50$ & 18.0 & 1.1 & NV & .- & - & $\mathrm{n} / \mathrm{a}$ & $\mathrm{n} / \mathrm{a}$ \\
\hline FL & 147.0 & $\$ 24.10$ & 72.5 & 0.8 & NY & $2,753.0$ & $\$ 24.60$ & $1,285.5$ & 69.2 \\
\hline GA & 986.0 & $\$ 23.80$ & 483.5 & 7.2 & $\mathrm{OH}$ & $3,331.0$ & $\$ 19.90$ & $1,653.5$ & 9.1 \\
\hline IA & 132.0 & $\$ 19.40$ & 53.5 & 9.5 & OK & 87.0 & $\$ 19.80$ & 40.5 & 2.3 \\
\hline ID & 29.0 & $\$ 24.70$ & 10.0 & 3.4 & OR & 134.0 & $\$ 22.70$ & 67.0 & -- \\
\hline IL & 200.0 & $\$ 22.70$ & 86.0 & 10.6 & PA & 474.0 & $\$ 22.40$ & 222.5 & 11.0 \\
\hline IN & 714.0 & $\$ 20.30$ & 325.5 & 23.9 & RI & 9.0 & $\$ 21.30$ & 4.5 & 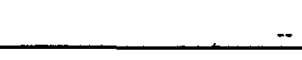 \\
\hline KS & 57.0 & $\$ 19.50$ & 21.5 & 5.3 & SC & 560.0 & $\$ 24.00$ & 278.0 & 1.5 \\
\hline KY & $4,218.0$ & $\$ 20.00$ & $1,867.0$ & 183.5 & $\mathrm{SD}$ & 2.0 & $\$ 19.70$ & 0.5 & 0.4 \\
\hline LA & 919.0 & $\$ 21.20$ & 437.5 & 16.7 & TN & $1,218.0$ & $\$ 20.90$ & 574.0 & 26.6 \\
\hline MA & 217.0 & $\$ 22.70$ & 101.5 & 5.3 & TX & 766.0 & $\$ 19.90$ & 375.0 & 6.1 \\
\hline $\mathrm{MD}$ & 346.0 & $\$ 23.60$ & 161.5 & 8.7 & UT & -- & $\mathrm{n} / \mathrm{a}$ & $\mathrm{n} / \mathrm{a}$ & $\mathrm{n} / \mathrm{a}$ \\
\hline $\mathrm{ME}$ & $3,523.0$ & $\$ 24.80$ & $1,645.0$ & 88.5 & VA & $1,589.0$ & $\$ 23.80$ & 746.0 & 36.9 \\
\hline MI & 862.0 & $\$ 20.00$ & 393.0 & 28.9 & VT & 629.0 & $\$ 24.80$ & 293.5 & 16.0 \\
\hline $\mathrm{MN}$ & 684.0 & $\$ 21.10$ & 295.5 & 35.3 & WA & 316.0 & $\$ 24.90$ & 145.0 & 9.9 \\
\hline MO & 832.0 & $\$ 19.50$ & 309.0 & 81.3 & WI & $1,227.0$ & $\$ 22.80$ & 596.5 & 12.9 \\
\hline MS & $1,770.0$ & $\$ 19.80$ & 851.5 & 25.5 & WV & $2,919.0$ & $\$ 23.80$ & $1,275.5$ & 139.8 \\
\hline $\mathrm{MT}$ & - & $\mathrm{n} / \mathrm{a}$ & $\mathrm{n} / \mathrm{a}$ & $\mathrm{n} / \mathrm{a}$ & WY & - & $\mathrm{n} / \mathrm{a}$ & $\mathrm{n} / \mathrm{a}$ & $\mathrm{n} / \mathrm{a}$ \\
\hline & & & & \multicolumn{2}{|l|}{ Total/Average } & $37,520.2$ & $\$ 22.32$ & $17,472.4$ & 978.5 \\
\hline
\end{tabular}

'Source: DOE EIA (1995) 
Table 18. Sof twood primary mill residue

\begin{tabular}{|c|c|c|c|c|c|c|c|c|c|}
\hline State & 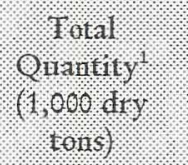 & (low & 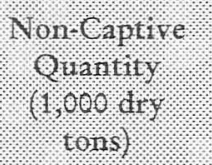 & W. & Stato & 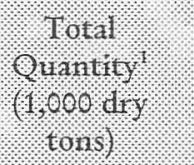 & (110e & 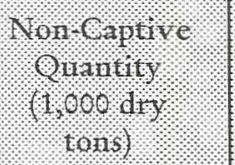 & א. \\
\hline $\mathrm{AL}$ & $4,243.0$ & $\$ 20.00$ & $2,091.5$ & 22.8 & $\mathrm{NC}$ & $3,456.0$ & $\$ 23.50$ & $1,697.0$ & 23.6 \\
\hline AR & $4,324.0$ & $\$ 20.60$ & $2,137.0$ & 19.0 & ND & - & $\mathrm{n} / \mathrm{a}$ & $\mathrm{n} / \mathrm{a}$ & $\mathrm{n} / \mathrm{a}$ \\
\hline $\mathrm{AZ}$ & 521.0 & $\$ 25.00$ & 251.0 & 7.2 & $\mathrm{NE}$ & 3.0 & $\$ 19.60$ & 1.5 & - \\
\hline $\mathrm{CA}$ & $6,232.0$ & $\$ 24.70$ & $3,089.5$ & 20.1 & $\mathrm{NH}$ & 790.0 & $\$ 24.80$ & 293.0 & 77.5 \\
\hline $\mathrm{CO}$ & 152.0 & $\$ 25.10$ & 27.0 & 37.2 & NI & 8.0 & $\$ 25.40$ & 4.0 & - \\
\hline $\mathrm{CT}$ & 31.0 & $\$ 24.60$ & 11.5 & 3.0 & NM & 279.0 & $\$ 25.00$ & 108.5 & 23.6 \\
\hline $\mathrm{DE}$ & 21.0 & $\$ 23.50$ & 7.5 & 2.3 & NV & 29.0 & $\$ 27.30$ & 14.5 & - \\
\hline $\mathrm{FL}$ & $2,406.0$ & $\$ 24.10$ & $1,202.0$ & 0.8 & NY & 944.0 & $\$ 24.60$ & 350.0 & 92.7 \\
\hline GA & $5,647.0$ & $\$ 23.80$ & $2,808.5$ & 11.4 & $\mathrm{OH}$ & 42.0 & $\$ 19.90$ & 20.5 & 0.4 \\
\hline IA & - & $\mathrm{n} / \mathrm{a}$ & $\mathrm{n} / \mathrm{a}$ & $\mathrm{n} / \mathrm{a}$ & $\mathrm{OK}$ & 550.0 & $\$ 19.80$ & 273.5 & 1.1 \\
\hline ID & $3,004.0$ & $\$ 24.70$ & $1,400.0$ & 77.5 & OR & $8,762.0$ & $\$ 22.70$ & $4,379.0$ & 1.5 \\
\hline IL & - & $\mathrm{n} / \mathrm{a}$ & $\mathrm{n} / \mathrm{a}$ & $\mathrm{n} / \mathrm{a}$ & PA & 2.0 & $\$ 22.40$ & 1.0 & - \\
\hline IN & 1.0 & $\$ 20.30$ & 0.5 & -- & RI & 5.0 & $\$ 21.30$ & 2.0 & 0.4 \\
\hline KS & - & $\mathrm{n} / \mathrm{a}$ & $\mathrm{n} / \mathrm{a}$ & $\mathrm{n} / \mathrm{a}$ & SC & $2,652.0$ & $\$ 24.00$ & $1,322.5$ & 2.7 \\
\hline KY & 300.0 & $\$ 20.00$ & 104.5 & 34.6 & SD & 327.0 & $\$ 19.70$ & 116.5 & 35.7 \\
\hline LA & $2,849.0$ & $\$ 21.20$ & $1,402.0$ & 17.1 & TN & 428.0 & $\$ 20.90$ & 211.0 & 2.3 \\
\hline MA & 53.0 & $\$ 22.70$ & 19.5 & 5.3 & TX & $2,925.0$ & $\$ 19.90$ & $1,441.5$ & 16.0 \\
\hline $\mathrm{MD}$ & 171.0 & $\$ 23.60$ & 63.5 & 16.7 & UT & 94.0 & $\$ 25.00$ & 33.5 & 10.3 \\
\hline $\mathrm{ME}$ & $5,223.0$ & $\$ 24.80$ & $1,935.5$ & 513.8 & VA & $1,199.0$ & $\$ 23.80$ & 587.0 & 9.5 \\
\hline MI & 217.0 & $\$ 20.00$ & 101.5 & 5.3 & VT & 702.0 & $\$ 24.80$ & 260.0 & 69.2 \\
\hline $\mathrm{MN}$ & 281.0 & $\$ 21.10$ & 118.5 & 16.7 & WA & $3,159.0$ & $\$ 24.90$ & $1,535.5$ & 33.4 \\
\hline $\mathrm{MO}$ & 72.0 & $\$ 19.50$ & 25.5 & 8.0 & WI & 244.0 & $\$ 22.80$ & 116.5 & 4.2 \\
\hline MS & $4,045.0$ & $\$ 19.80$ & $1,997.0$ & 19.4 & WV & 11.0 & $\$ 23.80$ & 5.5 & - \\
\hline MT & $2,282.0$ & $\$ 24.50$ & $1,045.0$ & 73.0 & WY & 311.0 & $\$ 25.00$ & 90.5 & 49.4 \\
\hline & & & & \multicolumn{2}{|l|}{ Total/Average } & $53,494.0$ & $\$ 22.75$ & $25,095.5$ & $1,255.4$ \\
\hline
\end{tabular}




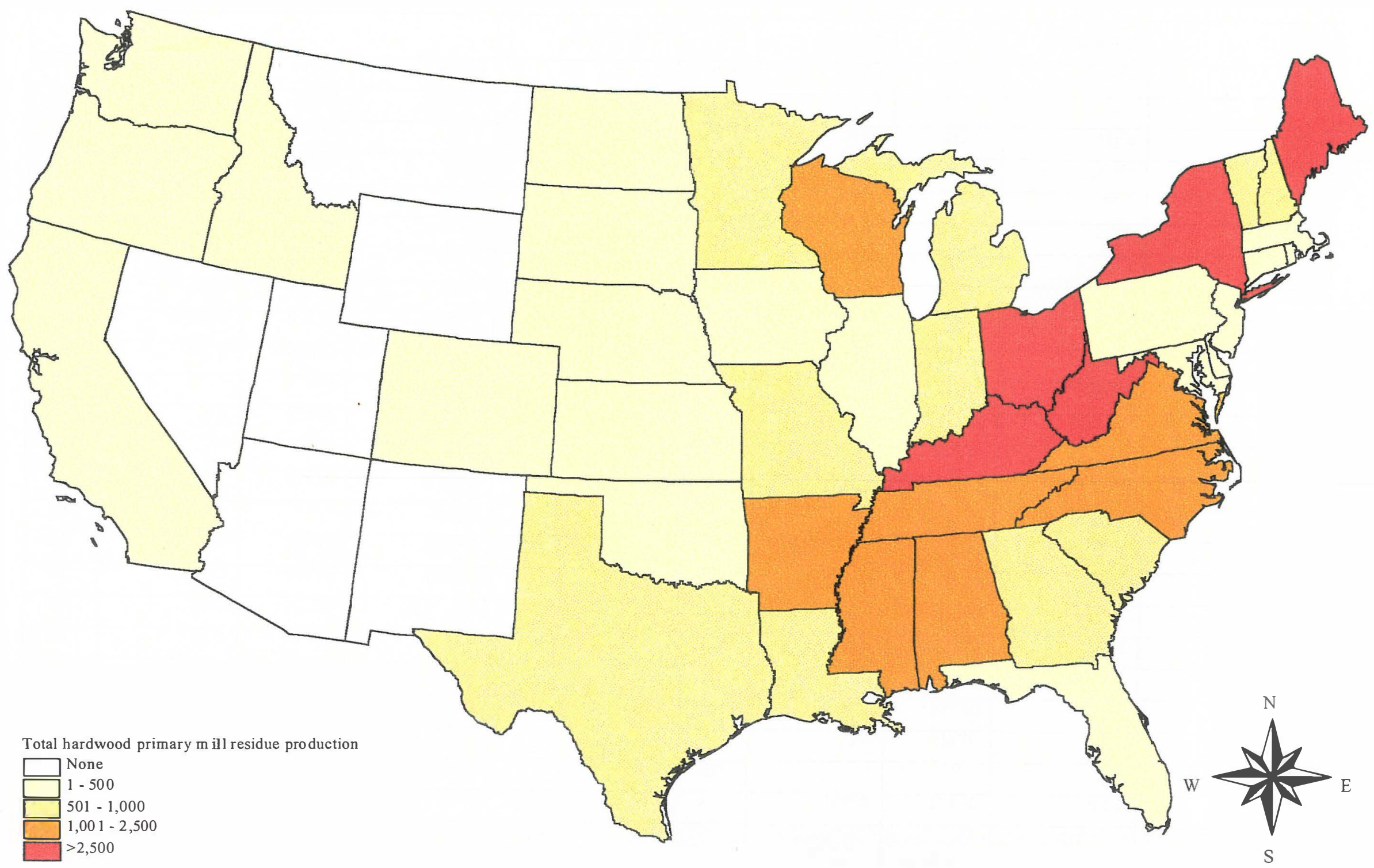

Figure 13. Total hardwood primary mill residue production (thousand dry tons/year) 


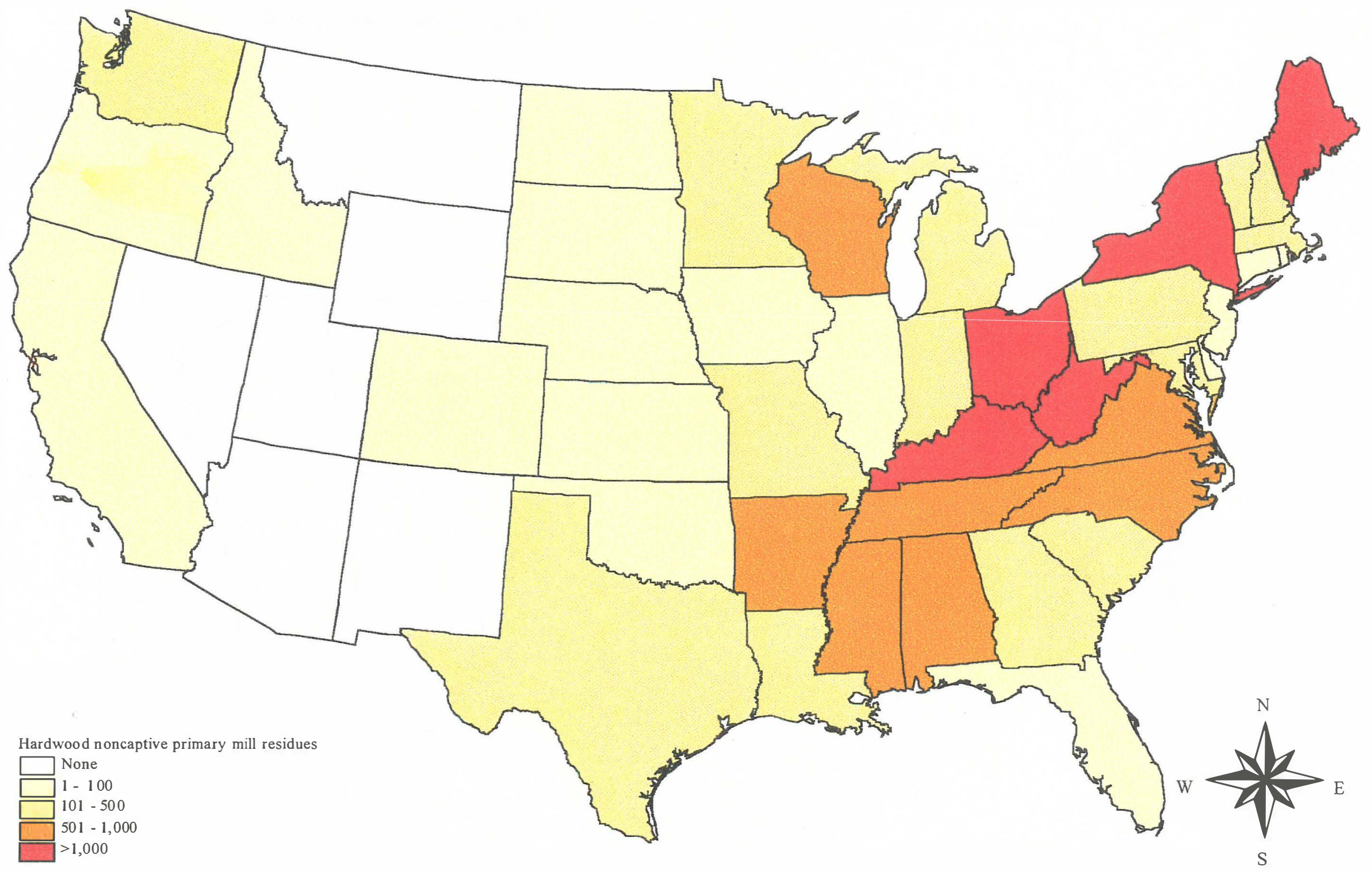

Figure 14. Hardwood primary mill residue used in non-captive markets (thousand dry tons/year) 


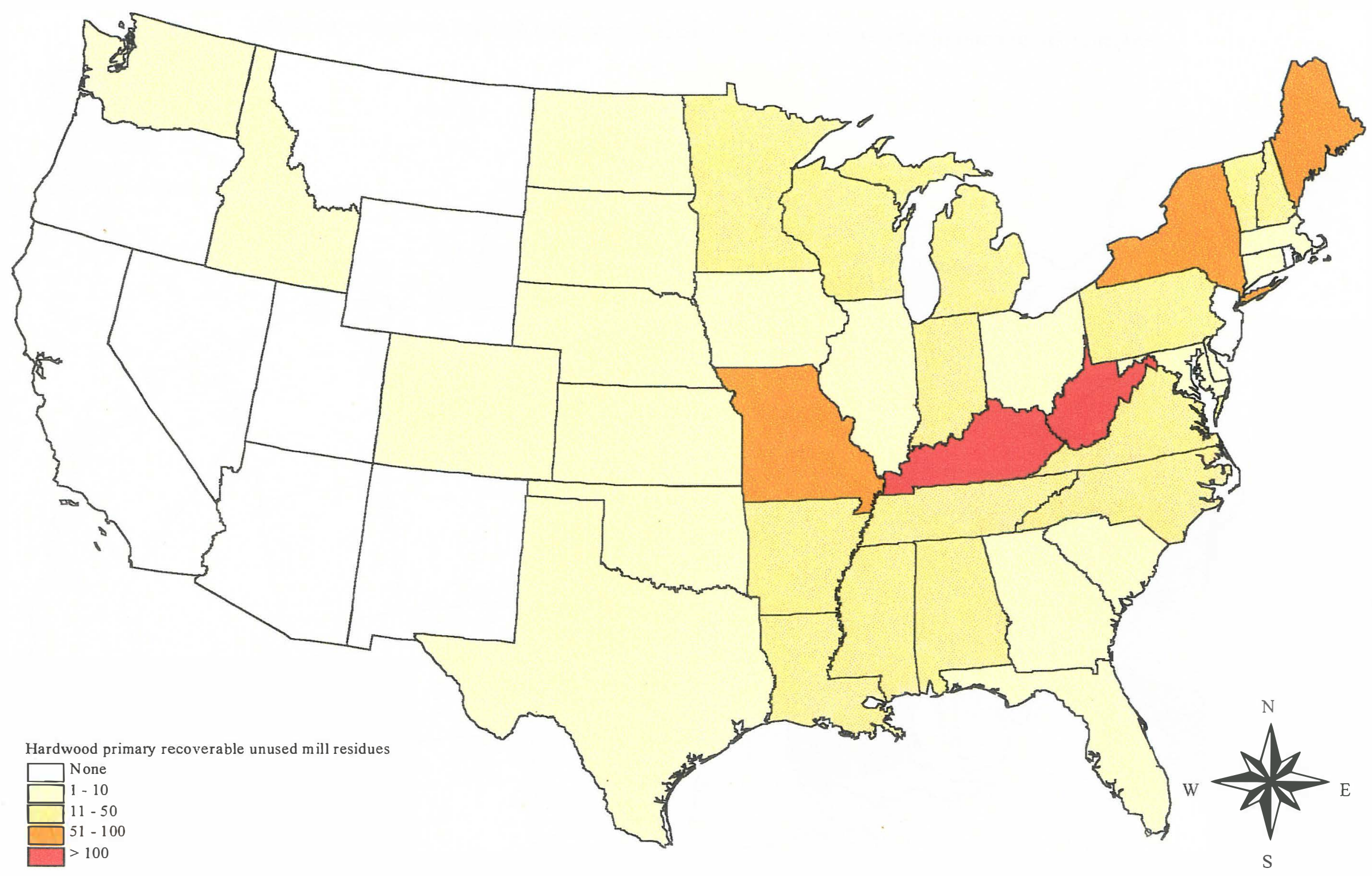

Figure 15. Recoverable unused hardwood primary mill residue (thousand dry tons/year) 


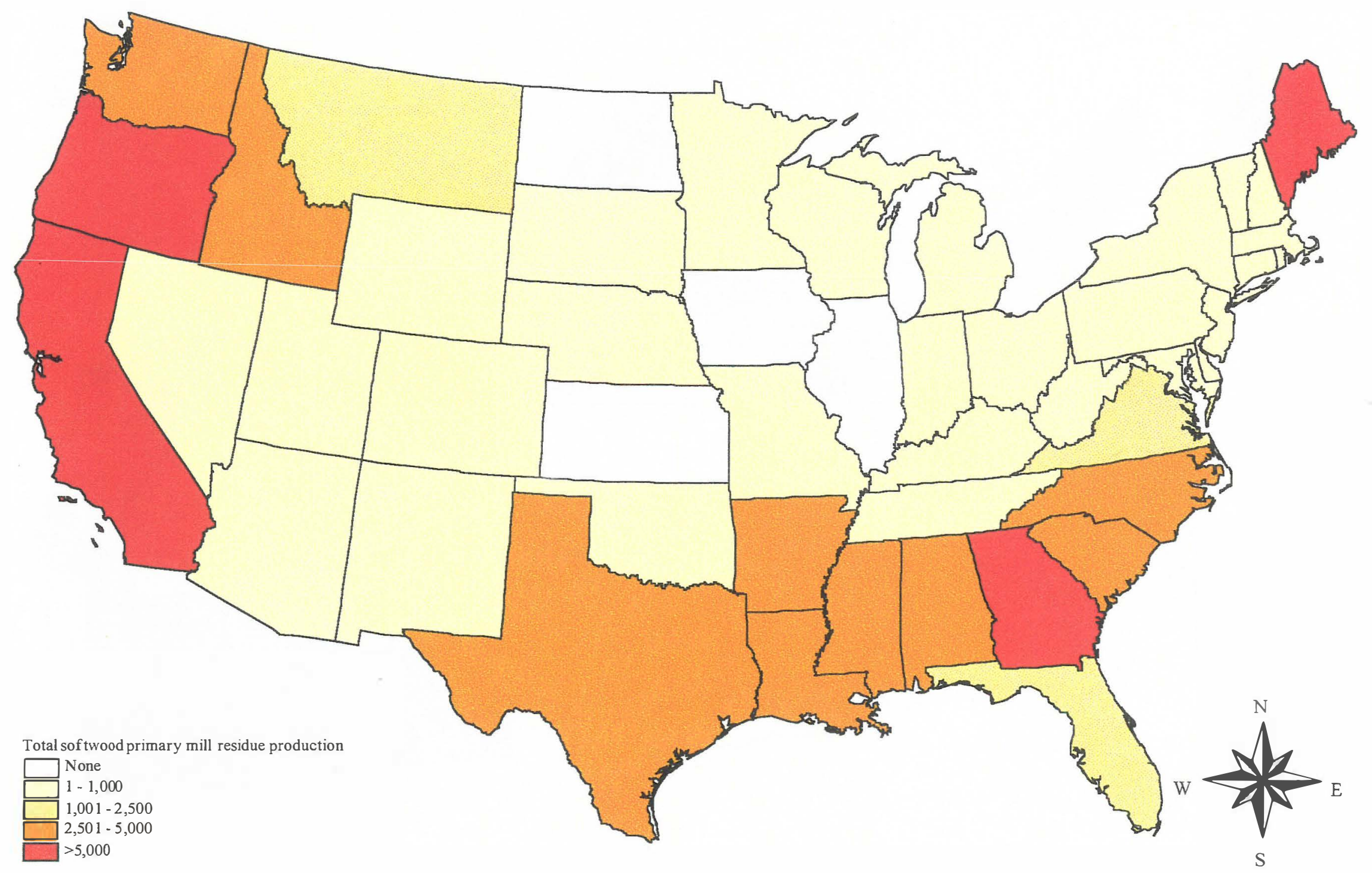

Figure 16. Total softwood primary mill residue production (thousand dry tons/year) 


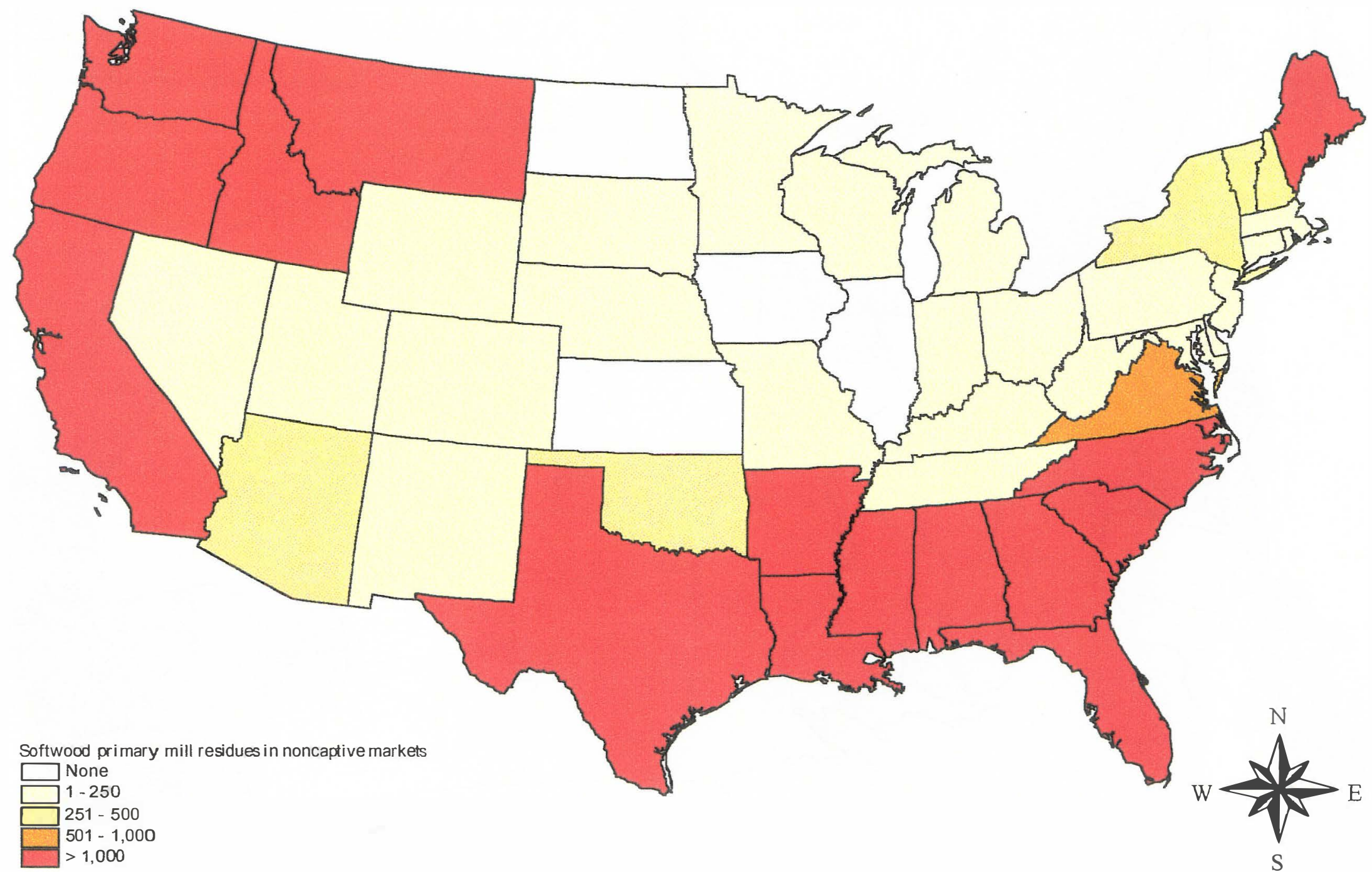

Figure 17. Softwood primary mill residue used in non-captive markets (thousand dry tons/year) 


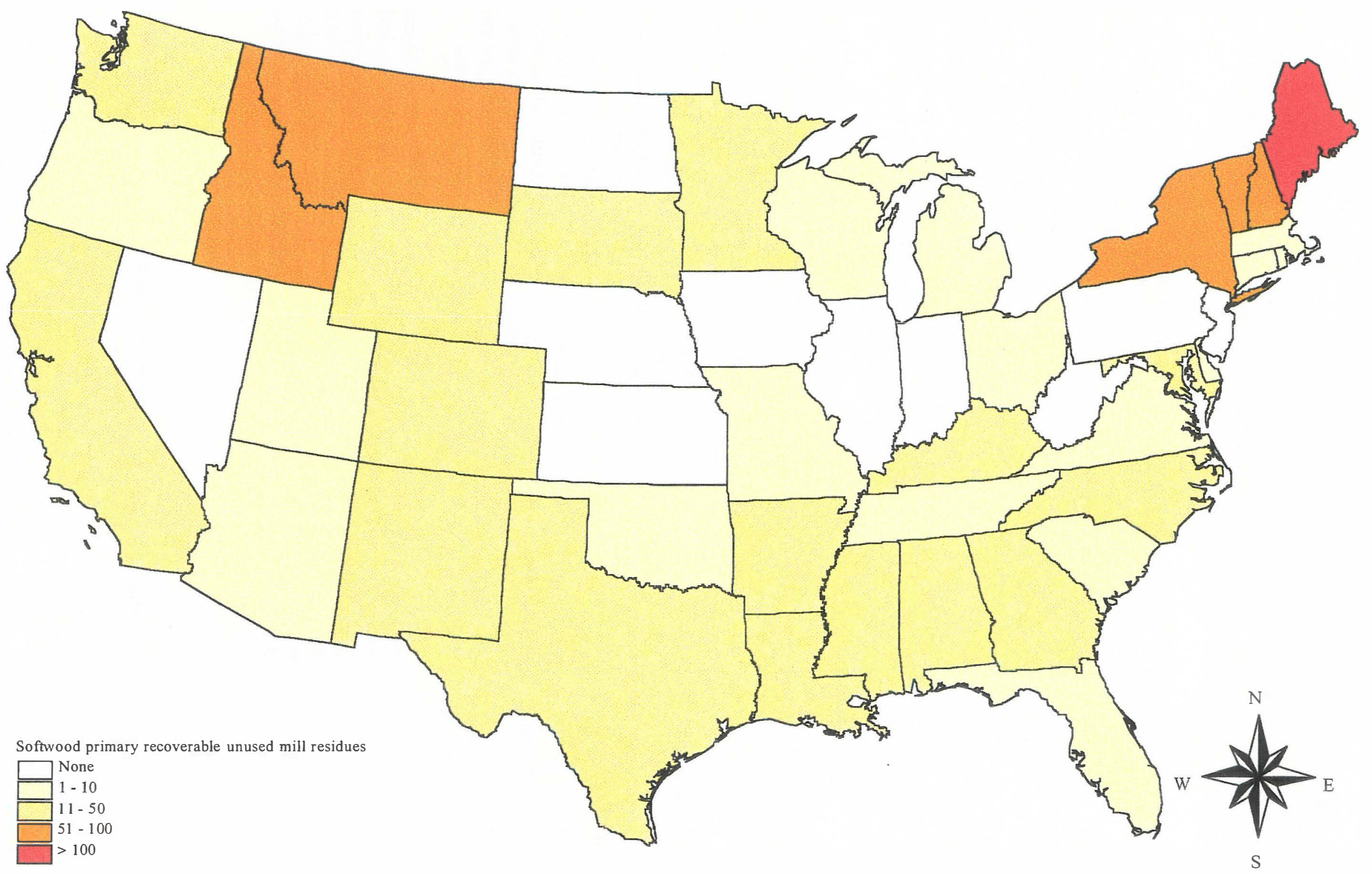

Figure 18. Recoverable unused softwood primary mill residue (thousand dry tons/year) 


\section{Secondary Mill Residues}

Hardwood secondary mill residue production within a state is not only a function of the presence of primary forest products industry. In some states with no hardwood primary forest products industry, secondary mills rely on hardwood components for manufacturing.

Table 19 lists total hardwood secondary mill residue quantities, price, quantities sold in non-captive markets, and unused but recoverable quantities of hardwood secondary mill residues. Several clusters of states demonstrate significant quantities of secondary hardwood mill residues that are used in non-captive markets. They include Pennsylvania/Ohio/West Virginia, Tennessee/Alabama, and Indiana/Missouri. Figure 20 shows the distribution of secondary hard wood residues currently used in non-captive markets but that may be available for use as an ethanol feedstock if a competitive price is offered for them. The distribution of unused but recoverable hardwood secondary residues follows the same pattern as noncaptive markets but in smaller quantities. Figure 21 shows the quantity of recoverable secondary hardwood residues that are landfilled or unused. The quality of these residues may be mixed. These residue sources will probably contain preservatives or metals because they can be discards from furniture manufacturing or other processes. The SIC codes for secondary mill residue establishments showing the types of manufacturing in this residue classification are given in Appendix B.

The Southeast, the Mississippi Delta, and the Pacific Northwest are all large softwood secondary forest products industry producers (Figure 22). This production, like that of hardwood secondary residue, can be found in locations fairly distant from softwood forests. Vermont shows large softwood secondary residue production. Idaho and New Mexico are large generators of secondary residues. Figure 23 portrays quantities of softwood secondary residues currently used in non-captive markets. Softwood secondary mill residues are often produced along with the manufacture of building components or prefabricated housing kits. These secondary residues are often in the form of trim ends and blocks that may be unusable as firewood and are more difficult than primary forest products industry residues to use in pulp manufacture. Secondary mill residues that require significant reprocessing are likely to be unused, landfilled, or given away by the producer. Figure 24 shows state-by-state quantities of softwood secondary residues that are currently unused or landfilled are small relative to total production. Table 20 provides data for total quantity, price, and quantity used in non-captive markets, and recoverable unused quantity of softwood secondary mill residues. Prices for secondary mill residue do not reflect state variation in the proportion of coarse and fine residues. State variation in residue particle size, which was available for primary mill residues, would have permitted a more precise characterization of variation in price between states.

Challenges associated with increasing the use of these residues include a large number of small producers, poorly established infrastructure for collection, transporting the residues, and producer unfamiliarity with market opportunities for residue use. Secondary mill residues are used for mulch, compost, and animal bedding. Some are also used to manufacture engineered wood products such as wood pellets and composite board. A large pellet plant or average composite board facility can use all residues in a 50-100 mile radius. These regional supply issues will shape the location and size of an ethanol industry depending on secondary residues as a raw material.

\section{Discussion}

Prices for mill residues vary greatly with local conditions, and in some cases these residues are made available by mills for a nominal fee or even at no charge. Weighting of state prices based on the relative proportion of fine and coarse residues captured a proportion of the variability which would be observed in residue prices between states. The variance of price estimates within states was not expressed in this study. Prices for coarse residues vary as a function of pulp and paper prices. States without current pulp markets and with coarse residue supplies may be sources of relatively low-cost, high-quality ethanol feedstock. Fine 
residues and bark are more of ten used in lower-value applications such as energy and mulch or compost applications. Western states of ten have greater available supplies of these residues than eastern states, in which dairy producers purchase most of the fines produced. During the next 20 years, technological advances in milling may decrease the residue coefficient, or the proportion of residues per unit of production. However, this will most likely not decrease the total quantity of residues produced, because of the increasing worldwide demand for forest products.

Secondary mill residue quantity estimates are subject to a greater degree of variability than primary mill residues, because of the lack of production capacity data by establishment. Two reasons for this are the large number of establishments and their tendency to produce a multitude of products. The SIC codes represented in this study incorporate approximately 89,000 establishments for the entire United States. Also, residue coefficients are not available for different products. Data for secondary forest products industries such as the Lockwood Post are either incomplete or not aggregated in a manner conducive to estimating residue quantities with current residue coefficients. A third reason (previously discussed) was the need for census data compilations to preserve the confidentiality of census respondents.

Some overlap may have occurred between primary and secondary mill residue quantity estimates because hardwood dimension and flooring mills were included with secondary industry. Some state forestry agencies included dimension and flooring mills with primary mills in forest products residue estimates; these estimates were included with secondary forest products industry in the current study. Also, establishments were classified based on their primary SIC code. This does not mean that these establishments did not produce other products, or that they did not respond differently to state forestry agencies when surveyed for RPA updates and assessments. This could have resulted in an overestimate of secondary residue production and total forest products industry production.

Ongoing work by faculty and staff at Pennsylvania State University and TVA will make residue coefficients by SIC code for the secondary forest products industry available for the Northeast and the Southeast in the beginning of 1998 (Johnson 1997; Palko 1997). Data for the Southeast, including information on the primary and secondary forest products industries, will be compiled and disseminated for 13 southeastern states by staff at the Southern Forest Experiment Station in Asheville, North Carolina, during the coming year. The combination of increased availability of establishment and residue data will increase the accuracy and usefulness of residue data in the future. However, even the new level of residue coefficient accuracy will not capture all the variability between states. Many products are included in SIC classifications, and there is a large degree of variation in the quantity of residues produced in a given production process. 
Table 19. Hardwood secondary mill residue

\begin{tabular}{|c|c|c|c|c|c|c|c|c|c|}
\hline State & 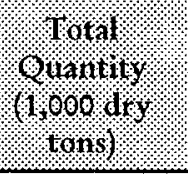 & 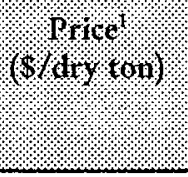 & 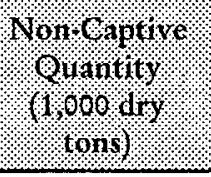 & 10mosed & S6re & 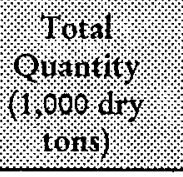 & 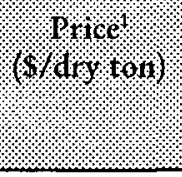 & Wonow & 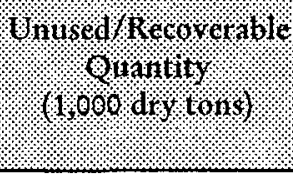 \\
\hline $\mathrm{AL}$ & 381.5 & $\$ 19.10$ & 110.9 & 36.8 & $\mathrm{NC}$ & 14.8 & $\$ 22.00$ & 4.2 & 1.6 \\
\hline $\mathrm{AR}$ & 35.1 & $\$ 19.90$ & 9.8 & 3.9 & ND & 24.4 & $\$ 22.00$ & 6.7 & 2.9 \\
\hline $\mathrm{AZ}$ & $\ldots$ & $\mathrm{n} / \mathrm{a}$ & $\mathrm{n} / \mathrm{a}$ & $\mathrm{n} / \mathrm{a}$ & $\mathrm{NE}$ & 48.8 & $\$ 18.50$ & 13.6 & 5.5 \\
\hline $\mathrm{CA}$ & 9.2 & $\$ 21.40$ & 2.6 & 1.0 & $\mathrm{NH}$ & 55.6 & $\$ 19.90$ & 15.2 & 6.7 \\
\hline $\mathrm{CO}$ & 9.5 & $\$ 21.40$ & 2.6 & 1.1 & NI & 35.4 & $\$ 19.90$ & 9.8 & 4.0 \\
\hline $\mathrm{CT}$ & 44.3 & $\$ 19.90$ & 12.1 & 5.3 & NM & $\ldots$ & $\mathrm{n} / \mathrm{a}$ & $\mathrm{n} / \mathrm{a}$ & $\mathrm{n} / \mathrm{a}$ \\
\hline $\mathrm{DE}$ & 10.3 & $\$ 22.00$ & 3.1 & 0.8 & $\mathrm{NV}$ & - & $\mathrm{n} / \mathrm{a}$ & $\mathrm{n} / \mathrm{a}$ & $\mathrm{n} / \mathrm{a}$ \\
\hline FL & 23.1 & $\$ 22.00$ & 6.4 & 2.7 & $\mathrm{NY}$ & 13.0 & $\$ 19.90$ & 3.7 & 1.3 \\
\hline GA & 46.4 & $\$ 22.00$ & 13.2 & 4.8 & $\mathrm{OH}$ & 393.9 & $\$ 17.30$ & 115.8 & 36.1 \\
\hline IA & 70.4 & $\$ 18.50$ & 20.1 & 7.3 & $\mathrm{OK}$ & 7.4 & $\$ 19.90$ & 2.0 & 0.9 \\
\hline ID & 3.6 & $\$ 21.40$ & 1.0 & 0.4 & $\mathrm{OR}$ & 6.2 & $\$ 21.40$ & 1.8 & 0.6 \\
\hline IL & 483.4 & $\$ 17.30$ & 140.5 & 46.6 & PA & 466.0 & $\$ 19.90$ & 133.2 & 48.0 \\
\hline IN & 93.5 & $\$ 17.30$ & 27.4 & 8.7 & RI & 7.9 & $\$ 19.90$ & 2.1 & 1.0 \\
\hline KS & 66.8 & $\$ 18.50$ & 18.8 & 7.3 & SC & 26.3 & $\$ 22.00$ & 7.5 & 2.7 \\
\hline KY & 124.7 & $\$ 19.10$ & 34.7 & 14.2 & SD & 0.1 & $\$ 18.50$ & -- & $\ldots$ \\
\hline LA & 20.8 & $\$ 19.90$ & 6.0 & 2.1 & $\mathbf{T N}$ & 389.1 & $\$ 19.10$ & 118.6 & 29.8 \\
\hline MA & 77.8 & $\$ 19.90$ & 22.3 & 7.9 & $\mathrm{TX}$ & 90.8 & $\$ 19.90$ & 25.9 & 9.5 \\
\hline MD & 59.5 & $\$ 22.00$ & 16.7 & 6.5 & UT & - & $\mathrm{n} / \mathrm{a}$ & $\mathrm{n} / \mathrm{a}$ & $\mathrm{n} / \mathrm{a}$ \\
\hline $\mathrm{ME}$ & 46.9 & $\$ 19.90$ & 12.9 & 5.5 & VA & 36.0 & $\$ 22.00$ & 10.1 & 4.0 \\
\hline MI & 212.5 & $\$ 19.90$ & 59.5 & 23.6 & VT & 228.8 & $\$ 19.90$ & 70.0 & 17.2 \\
\hline $\mathrm{MN}$ & 133.1 & $\$ 18.50$ & 37.8 & 14.0 & WA & 23.2 & $\$ 21.40$ & 6.5 & 2.6 \\
\hline $\mathrm{MO}$ & 465.9 & $\$ 18.50$ & 141.9 & 35.8 & WI & 45.6 & $\$ 17.30$ & 12.7 & 5.2 \\
\hline MS & 81.3 & $\$ 19.10$ & 24.3 & 6.9 & WV & 414.3 & $\$ 22.00$ & 123.1 & 36.2 \\
\hline MT & $\ldots$ & $\mathrm{n} / \mathrm{a}$ & $\mathrm{n} / \mathrm{a}$ & $\mathrm{n} / \mathrm{a}$ & WY & -- & $\mathrm{n} / \mathrm{a}$ & $\mathrm{n} / \mathrm{a}$ & $\mathrm{n} / \mathrm{a}$ \\
\hline & & & & \multicolumn{2}{|l|}{ Total/Average } & $4,827.2$ & $\$ 20.10$ & $1,407.3$ & 459.1 \\
\hline
\end{tabular}

${ }^{1}$ Source: DOE EIA (1997) 
Table 20. Softwood secondary mill residue

\begin{tabular}{|c|c|c|c|c|c|c|c|c|c|}
\hline State & 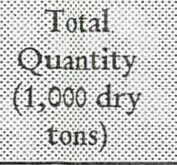 & $\left(\begin{array}{l}\text { Plife } \\
(8)\end{array}\right.$ & 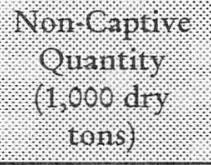 & (1) & s. & 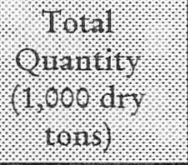 & 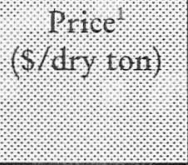 & 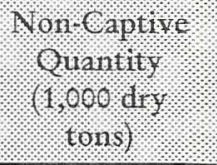 & (1) \\
\hline $\mathrm{AL}$ & $1,083.4$ & $\$ 19.10$ & 314.9 & 104.4 & $\mathrm{NC}$ & 28.4 & $\$ 22.00$ & 8.1 & 3.0 \\
\hline $\mathrm{AR}$ & 101.9 & $\$ 19.90$ & 28.5 & 11.4 & ND & 0.2 & $\$ 22.00$ & - & - \\
\hline $\mathrm{AZ}$ & 232.7 & $\$ 21.40$ & 68.8 & 20.8 & $\mathrm{NE}$ & 4.7 & $\$ 18.50$ & 1.3 & 0.5 \\
\hline $\mathrm{CA}$ & $1,101.2$ & $\$ 21.40$ & 308.5 & 122.2 & $\mathrm{NH}$ & 59.6 & $\$ 19.90$ & 16.3 & 7.2 \\
\hline $\mathrm{CO}$ & 62.9 & $\$ 21.40$ & 17.3 & 7.4 & NI & 6.4 & $\$ 19.90$ & 1.8 & 0.7 \\
\hline $\mathrm{CT}$ & 8.7 & $\$ 19.90$ & 2.4 & 1.1 & NM & 382.1 & $\$ 21.40$ & 107.4 & 41.9 \\
\hline $\mathrm{DE}$ & 5.6 & $\$ 22.00$ & 1.7 & 0.5 & NV & $1,324.0$ & $\$ 21.40$ & 399.3 & 107.5 \\
\hline $\mathrm{FL}$ & 378.9 & $\$ 22.00$ & 105.0 & 43.6 & $\mathrm{NY}$ & 4.5 & $\$ 19.90$ & 1.3 & 0.4 \\
\hline GA & 265.7 & $\$ 22.00$ & 75.7 & 27.6 & $\mathrm{OH}$ & 5.0 & $\$ 17.30$ & 1.5 & 0.5 \\
\hline IA & - & $\mathrm{n} / \mathrm{a}$ & $\mathrm{n} / \mathrm{a}$ & $\mathrm{n} / \mathrm{a}$ & OK & 47.1 & $\$ 19.90$ & 12.9 & 5.7 \\
\hline ID & 368.4 & $\$ 21.40$ & 104.5 & 39.1 & OR & 407.1 & $\$ 21.40$ & 118.9 & 38.4 \\
\hline IL & - & $\mathrm{n} / \mathrm{a}$ & $\mathrm{n} / \mathrm{a}$ & $\mathrm{n} / \mathrm{a}$ & PA & 2.0 & $\$ 19.90$ & 0.6 & 0.2 \\
\hline IN & 0.1 & $\$ 17.30$ & - & - & $\mathrm{RI}$ & 4.4 & $\$ 19.90$ & 1.2 & 0.6 \\
\hline $\mathrm{KS}$ & - & $\mathrm{n} / \mathrm{a}$ & $\mathrm{n} / \mathrm{a}$ & $\mathrm{n} / \mathrm{a}$ & SC & 124.4 & $\$ 22.00$ & 35.6 & 12.7 \\
\hline $\mathrm{KY}$ & 8.9 & $\$ 19.10$ & 2.5 & 1.0 & $\mathrm{SD}$ & 21.0 & $\$ 18.50$ & 6.0 & 2.2 \\
\hline LA & 64.4 & $\$ 19.90$ & 18.5 & 6.5 & TN & 136.7 & $\$ 19.10$ & 41.7 & 10.5 \\
\hline MA & 19.0 & $\$ 19.90$ & 5.4 & 1.9 & $T X$ & 346.9 & $\$ 19.90$ & 98.8 & 36.2 \\
\hline $\mathrm{MD}$ & 29.4 & $\$ 22.00$ & 8.3 & 3.2 & UT & 70.7 & $\$ 21.40$ & 19.9 & 7.7 \\
\hline $\mathrm{ME}$ & 69.5 & $\$ 19.90$ & 19.1 & 8.2 & VA & 27.2 & $\$ 22.00$ & 7.6 & 3.0 \\
\hline $\mathrm{MI}$ & 53.5 & - $\$ 19.90$ & 15.0 & 5.9 & VT & 255.3 & $\$ 19.90$ & 78.1 & 19.1 \\
\hline $\mathrm{MN}$ & 54.7 & $\$ 18.50$ & 15.5 & 5.8 & WA & 232.0 & $\$ 21.40$ & 65.0 & 25.7 \\
\hline $\mathrm{MO}$ & 40.3 & $\$ 18.50$ & 12.3 & 3.1 & WI & 9.1 & $\$ 17.30$ & 2.5 & 1.0 \\
\hline MS & 185.9 & $\$ 19.10$ & 55.5 & 15.8 & WV & 1.6 & $\$ 22.00$ & 0.5 & 0.1 \\
\hline MT & 43.2 & $\$ 21.40$ & 12.5 & 4.2 & WY & 9.5 & $\$ 21.40$ & 2.6 & 1.2 \\
\hline & & & & \multicolumn{2}{|l|}{ Total/Average } & $7,688.1$ & $\$ 20.03$ & $2,220.5$ & 760.0 \\
\hline
\end{tabular}




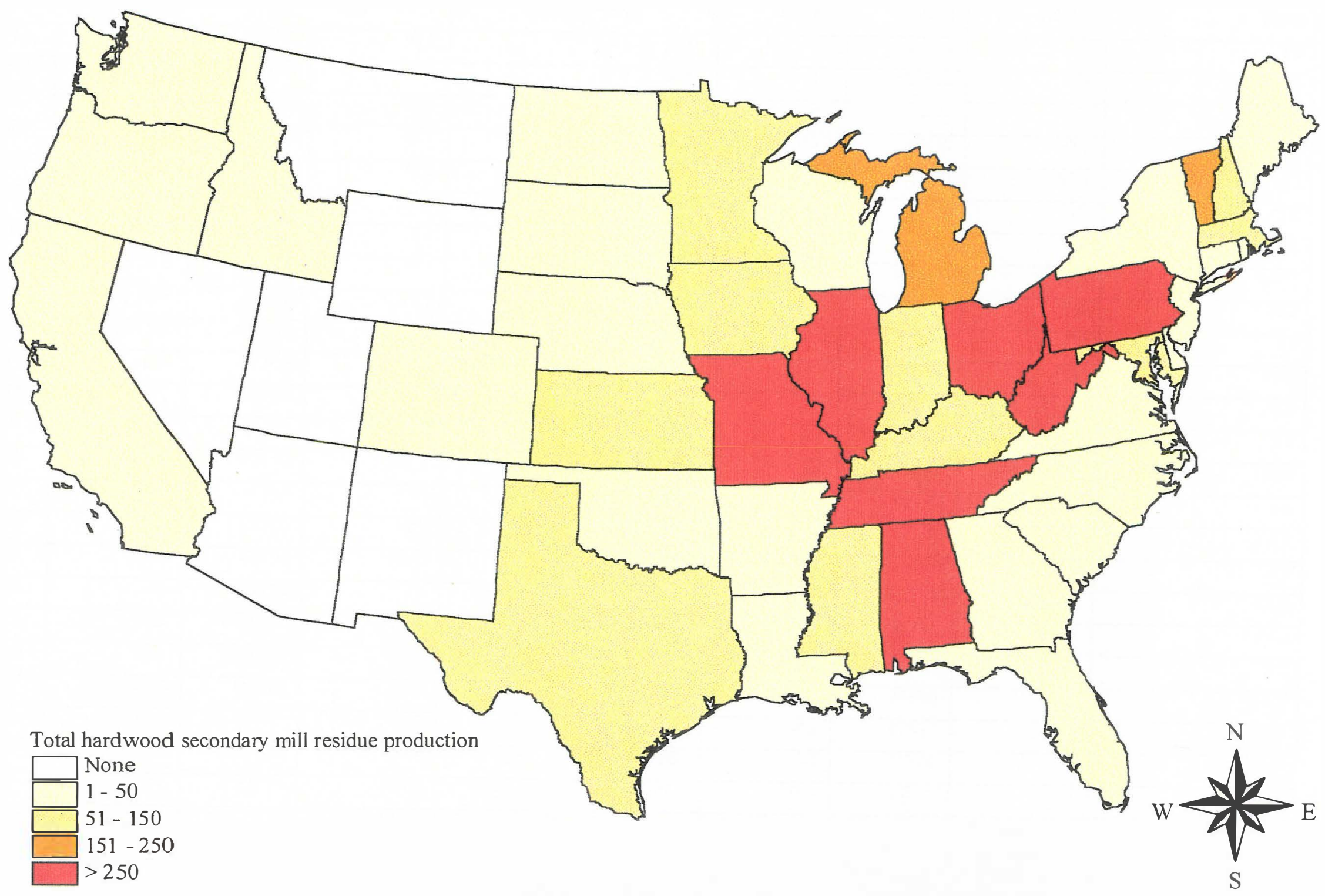

Figure 19. Total hardwood secondary mill residue production (thousand dry tons/year) 


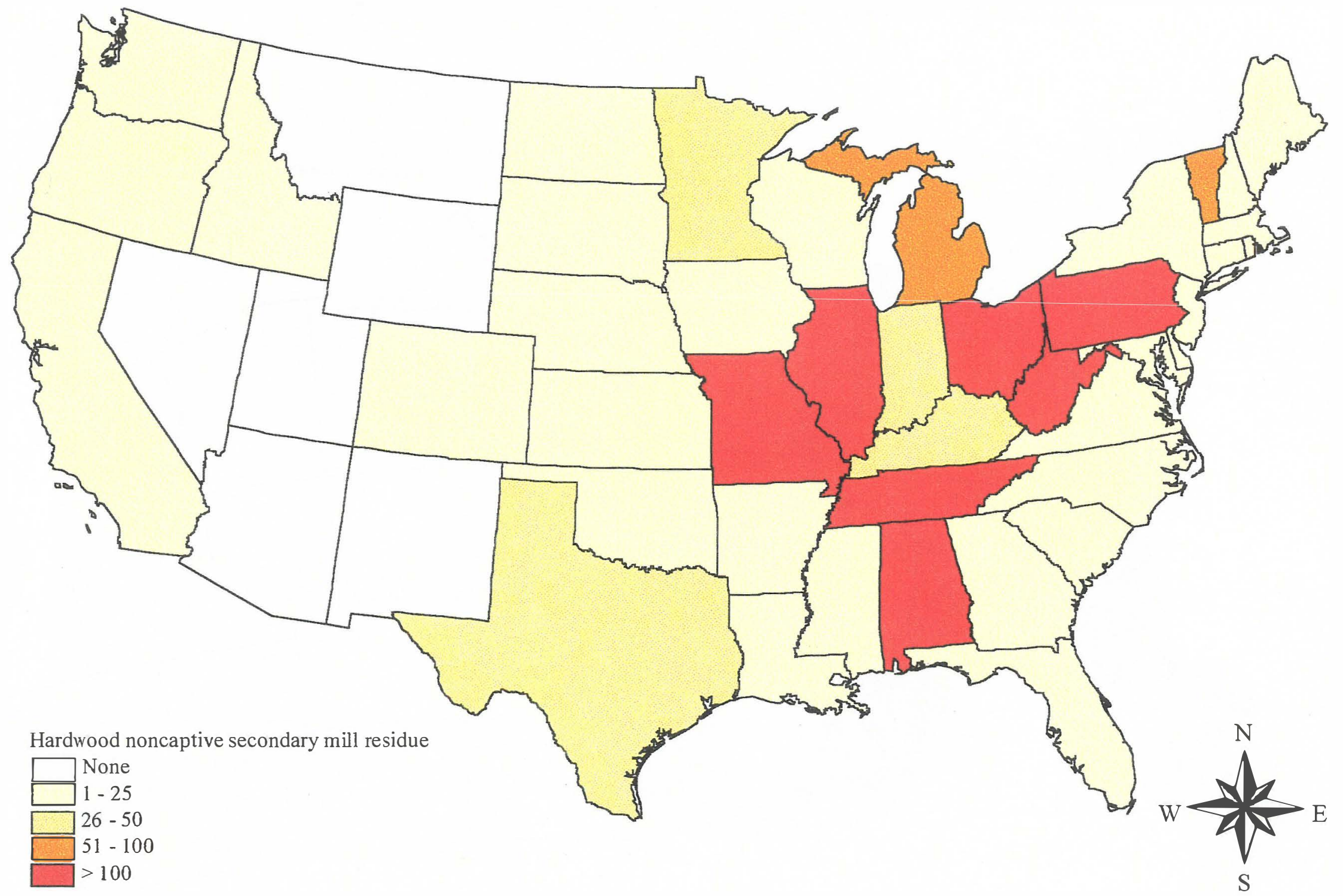

Figure 20. Hardwood secondary mill residue used in non-captive markets (thousand dry tons/year) 


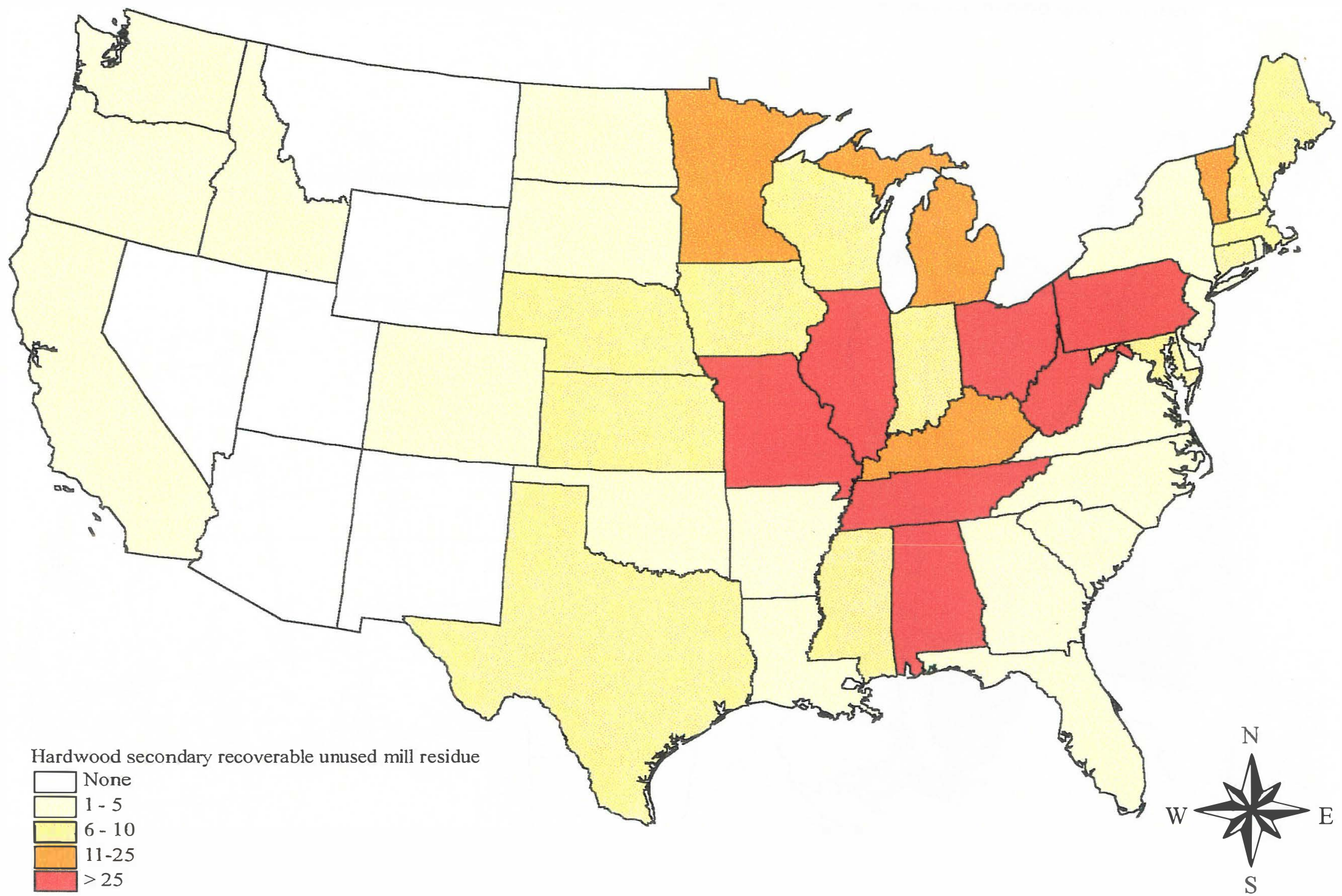

Figure 21. Recoverable unused hardwood secondary mill residues (thousand dry tons/year) 


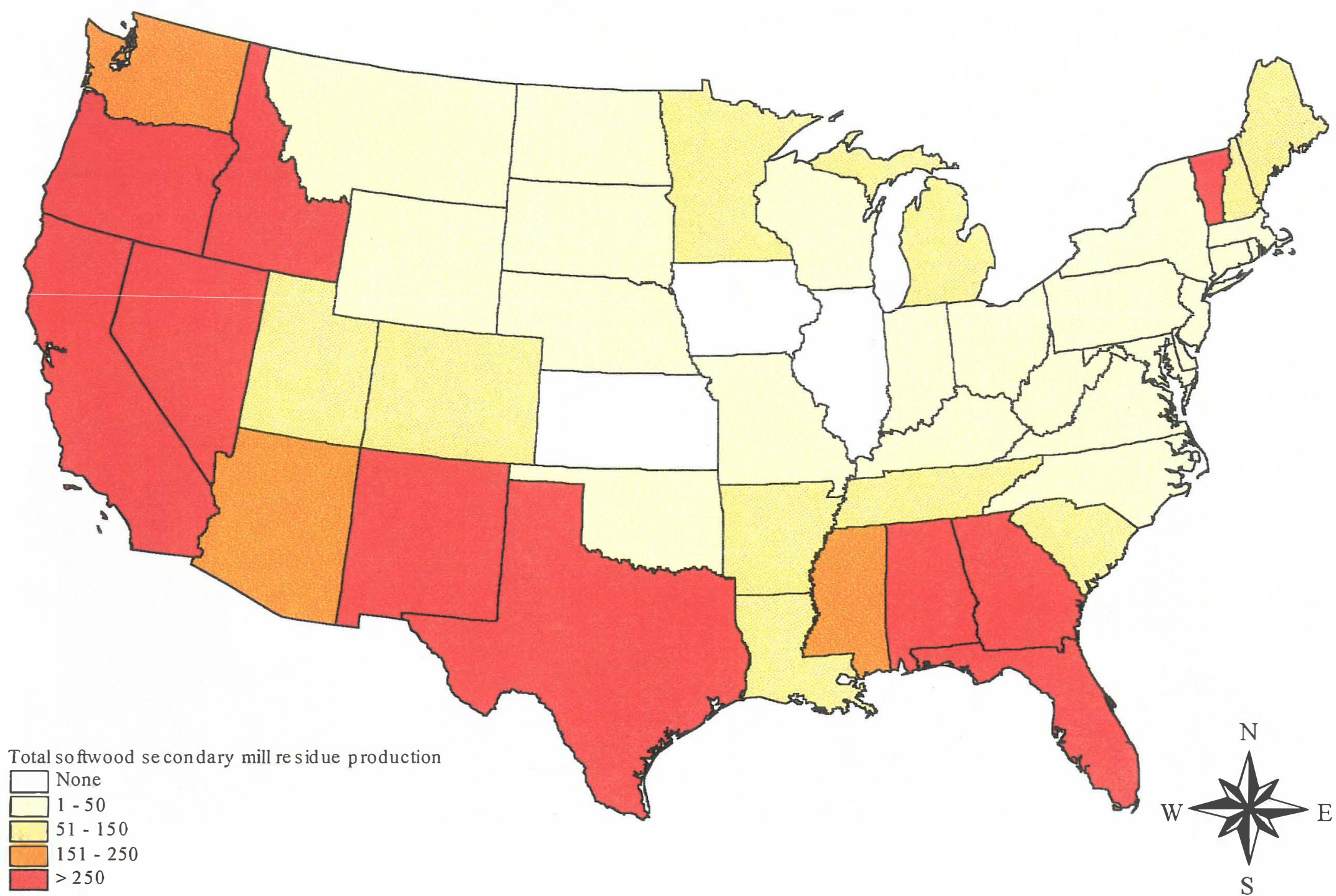

Figure 22. Total softwood secondary mill residue production (thousand dry tons/year) 


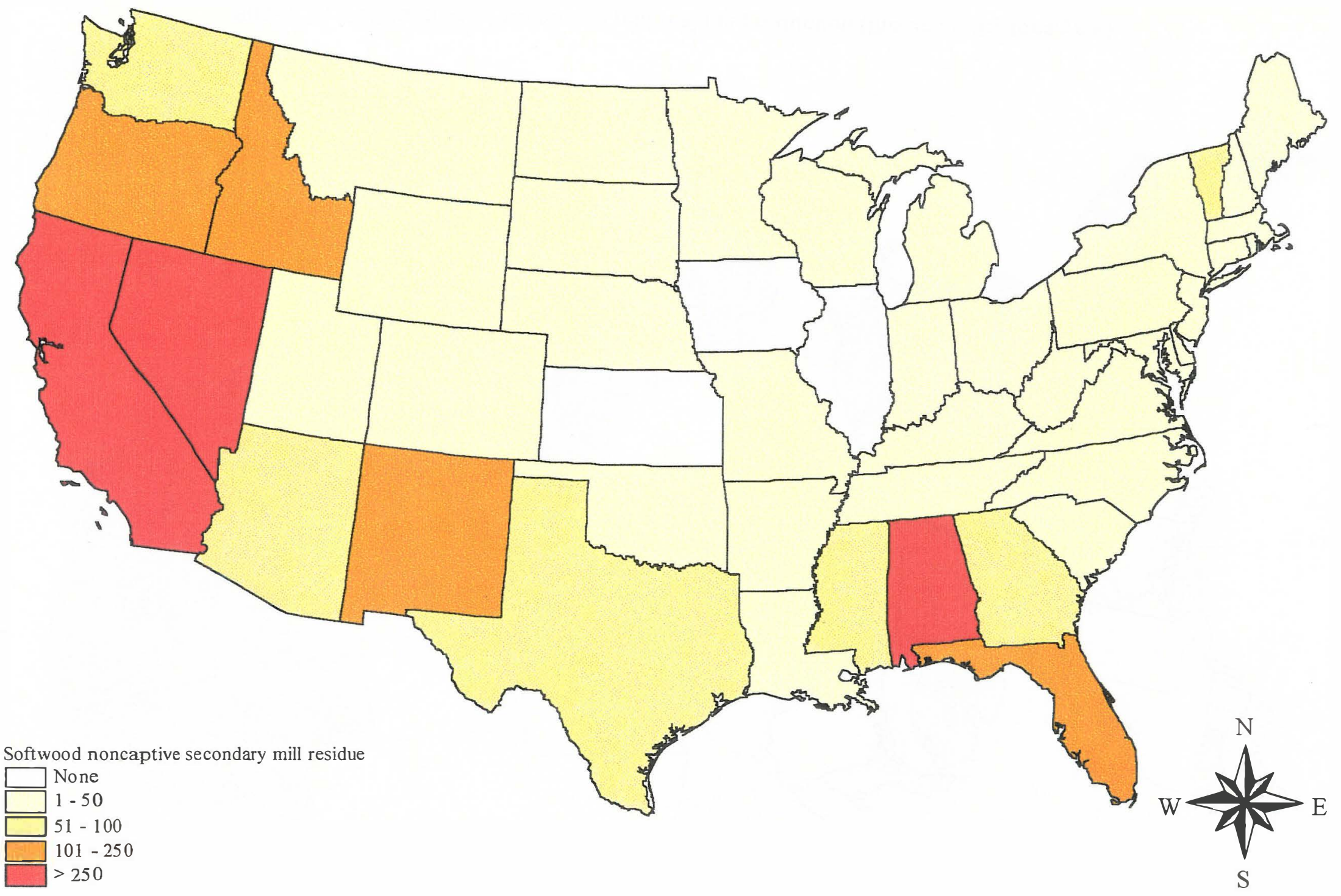

Figure 23. Secondary softwood mill residues used in non-captive markets (thousand dry tons/year) 


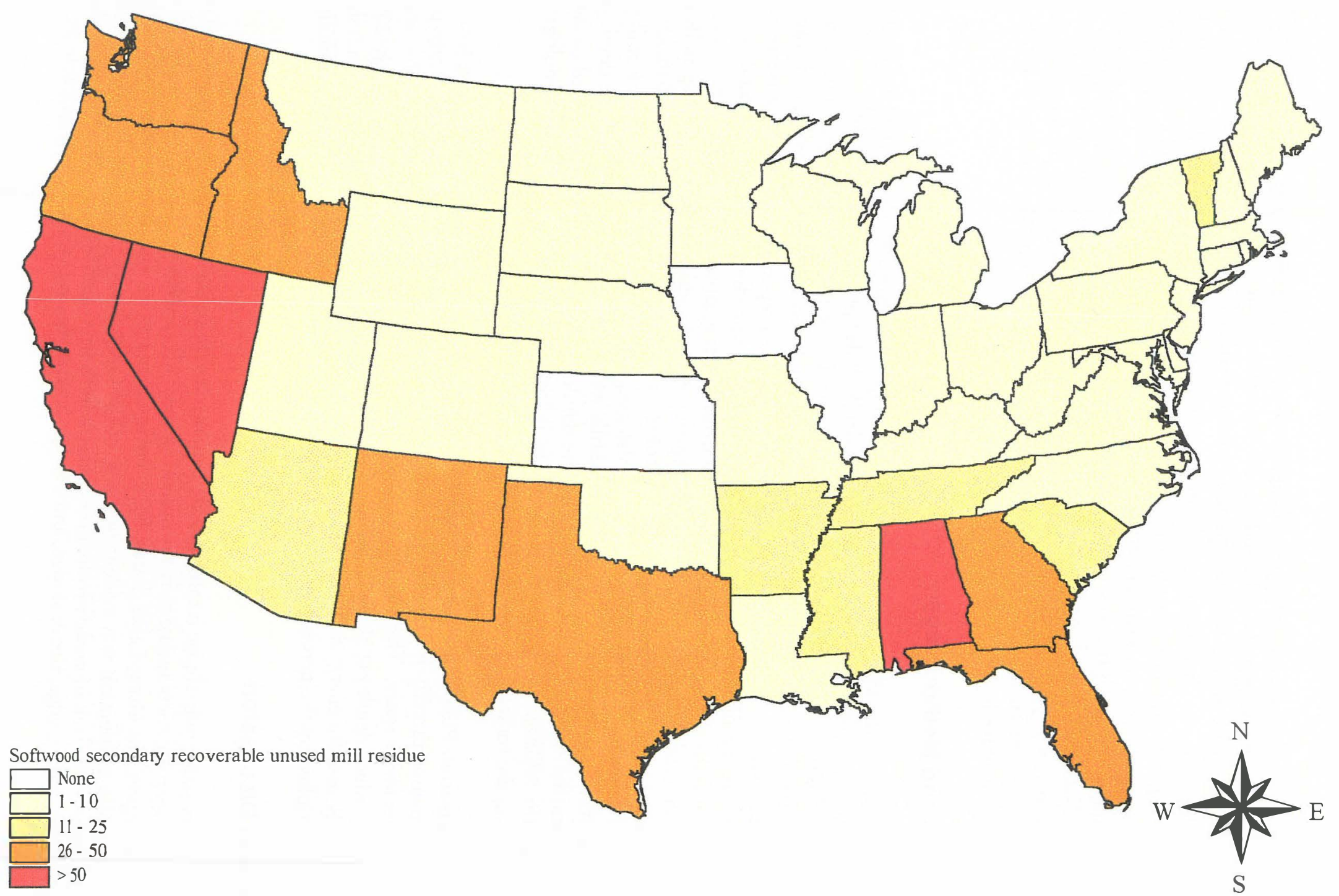

Figure 24. Recoverable unused softwood secondary mill residues (thousand dry tons/year) 


\section{Recycled Primary Paper Pulp Sludge}

This resource assessment focuses on one type of sludge produced by pulp and paper mills, primary pulp sludge from wastepaper deinking mills. Pulp sludge is the residue resulting from the chemical or mechanical processing of feedstocks such as wood chips and recovered paper for the production of paper pulp. Primary pulp sludge is the raw sludge emerging from the pulping process before it undergoes any further processing. Deinking mills use post-consumer printed wastepaper as a feedstock for the pulping process instead of paper by-products from manufacturing processes or new feedstocks such as wood chips. The process for deinking wastepaper produces a larger volume of primary sludge than other pulping processes. According to the National Council for Air and Stream Improvement (NCASI), deinking mills produce a mean of $539 \mathrm{dry} \mathrm{lb} / \mathrm{ton}$ of paper production (NCASI 1994). The next largest sludge producers, groundwood mills, produce a mean of only $141 \mathrm{dry} \mathrm{lb} / \mathrm{ton}$ of paper production. Most sludge is landfilled, although a small percentage is applied to land or combusted.

\section{Data Sources and Methodology}

An electronic database of the 1997 Lockwood-Post's Directory of the Pulp, Paper and Allied Trades (Dyer 1997) provided state-level information on the amount of deink sludge produced in the United States. The data contained in this directory are from 1996. The electronic database of pulp and paper mills contains information on paper and pulp capacities, pulping processes employed by individual mills, and amounts of pulp produced by North American mills. From this database, two reports were used to generate quantities of pulp produced by all mills that use a deinking process. Pulp production data in the database were missing for several mills that were listed as using the deink pulping process. For missing data, average production values for deink mills were applied to the missing mills. In addition, paper and pulp mills that use post-consumer wastepaper such as mixed paper, computer paper, and magazines as feedstocks were assumed to use a deinking process. These mills were also assigned the average figure for deink mill pulp production if that number was not already provided. Mills were then sorted by state and the deink pulp production quantities were totaled for each state. The deink pulp quantities were converted to sludge quantities using the NCASI conversion factor of 539 dry lb/ton of deinked pulp. This methodology was followed to obtain the total sludge quantities for all pulping processes.

Chartwell Information Publishers (CIP) provided state-by-state paper sludge disposal tipping fees. CIP receives its information directly from landfill facilities (Thompson 1997), and contributed average paper sludge tipping fees for 38 states. These 38 fees were averaged and the resulting figure was used for remaining states that produce deink paper sludge but were missing from the CIP list. Approximately $20 \%$ of sludge is currently used for energy and compost, and 80\% is landfilled (Skog and Rosen 1997). Total sludge production multiplied by the percentage of sludge landfilled provided estimates of sludge availability.

\section{Results and Discussion}

Recycled primary paper pulp sludge is most heavily concentrated in states with high populations and those in which the paper products industry is prominent (Figure 25). Sludge production was highest in the Pacific Coast region, the Great Lakes States, New York, Connecticut, and the Mississippi Delta States. Little or no sludge production was evident in many of the Great Plains States, the Southwest, and the Midwest because of the lack of paper production capacity in those regions (Figure 25). Numeric data for pulp, deink pulp, total sludge, deink sludge, and average landfill tipping fees are given in Table 21.

Deink sludge availability is based on the difference between estimated total quantities produced and quantities used for energy and compost (Figure 26). Most sludge is landfilled, landspread, or incinerated for process heat (despite high moisture content, combustion is less costly than landfilling in many cases). This study assumes that $80 \%$ of all sludge is landfilled or used in low-value applications and is thus available for 
use in ethanol production (Skog and Rosen 1997). Paper sludge availability closely resembles quantity because of the low rate of paper sludge use for high value-added applications (Figure 26).

Tipping fees are a proxy for recycled paper pulp sludge prices. They are negatively priced, which means a fee may be charged for accepting them from paper producers. A negative price aids in the profitability of ethanol production from primary paper pulp sludge relative to other feedstocks. The negative feedstock price could create a niche market for ethanol from cellulosic materials for production facilities on site (Kerstetter et al. 1997). Landfill tipping prices for sludge on a state level ranged from $\$ 3.12$ to $\$ 69.77 /$ dry ton (Table 21). A value of $\$ 0$ was reported for Massachusetts. Whether this is due to the absence of data for sludge in Massachusetts (because of the low volume of sludge disposal relative to other states) or to the lack of a tipping fee in that state, is unclear. States with high tipping fees of note are concentrated in the Northeast and include Connecticut, Delaware, New York, Rhode Island, Pennsylvania, New Hampshire, and Maryland. In the event that sludge is used for energy applications in a mill, the price may be more closely approximated by the cost of electrical or steam capacity foregone minus the landfill tipping fee.

Sludge production from a survey of 11 mills in the Pacific Northwest by Kerstetter et al. (1997) showed sludge production in the range of 9 to 170 dry tons/day, which corresponds to an annual ethanol production potential of 126,000 to 3.2 million gallons. The size of the ethanol plant can dramatically affect profitability of ethanol production, as well as the cost of the feedstock. The mill with the largest sludge production showed the highest internal rate of return, $14.8 \%$. These researchers showed that ethanol production became unprofitable for mills with sludge production less than 50 dry tons/day.

Three determinants of economic viability for ethanol production from paper sludge are: available carbohydrate fraction, reactivity of the feedstock as received, and disposal cost. Most sludges demonstrate a glucose content of $40 \%-60 \%$ and a carbohydrate fraction of $50 \%-75 \%$. Reactivity of paper pulp sludge is difficult to correlate with pulping process. The efficiency conversion of cellulose and xylose to ethanol ranged from $36 \%-100 \%$ for the mills surveyed. Only one mill surveyed was considered economically viable, in part because it was a deink mill and had substantial landfill costs associated with its waste materials (\$45/dry ton) (Kerstetter et al. 1997). 
Table 21. Total paper pulp, total sludge, deink pulp, deink sludge production estimates, and tipping fees

\begin{tabular}{|c|c|c|c|c|c|c|}
\hline Strate. & $(1091 / \mathrm{p}+11 \mathrm{p} / \mathrm{s}$ & 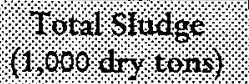 & (1.08067ons) & 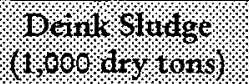 & oratiable: & T) \\
\hline $\mathrm{AL}$ & 8,799 & 524 & 771 & 208 & 166.3 & $\$ 33.64$ \\
\hline AR & 2,974 & 177 & 236 & 64 & 50.9 & $\$ 25.40$ \\
\hline $\mathrm{AZ}$ & 546 & 32 & 163 & 44 & 35.2 & $\$ 18.86$ \\
\hline $\mathrm{CA}$ & 884 & 53 & 380 & 103 & 82.0 & $\$ 36.81$ \\
\hline CT & 324 & 19 & - & - & - & $\$ 69.77$ \\
\hline $\mathrm{DE}$ & 7 & - & 118 & 32 & 25.4 & $\$ 58.50$ \\
\hline $\mathrm{FL}$ & 4,210 & 250 & 118 & 32 & 25.4 & $\$ 56.27$ \\
\hline GA & 8,598 & 512 & 1,272 & 343 & 274.3 & $\$ 32.45$ \\
\hline IA & 53 & 3 & - & - & - & $\$ 35.77$ \\
\hline ID & 455 & 27 & - & - & - & $\$ 38.38$ \\
\hline IL & 263 & 71 & 263 & 71 & 56.6 & $\$ 23.84$ \\
\hline IN & 187 & 11 & 348 & 94 & 75.0 & $\$ 27.96$ \\
\hline $\mathrm{KY}$ & 786 & 47 & 118 & 32 & 25.4 & $\$ 36.51$ \\
\hline LA & 5,675 & 338 & 472 & 127 & 101.8 & $\$ 28.00$ \\
\hline MA & 839 & 50 & 593 & 160 & 127.9 & - \\
\hline $\mathrm{MD}$ & 651 & 39 & 350 & 94 & 75.5 & $\$ 51.67$ \\
\hline $\mathrm{ME}$ & 3,433 & 204 & 428 & 115 & 92.4 & $\$ 32.21$ \\
\hline MI & 2,749 & 164 & 915 & 247 & 197.3 & $\$ 30.36$ \\
\hline MN & 1,526 & 91 & 411 & 111 & 88.6 & $\$ 3.12$ \\
\hline MO & 21 & 1 & 118 & 32 & 25.4 & $\$ 19.70$ \\
\hline MS & 4,219 & 251 & 398 & 107 & 85.8 & $\$ 32.21$ \\
\hline MT & 560 & 33 & - & - & - & $\$ 18.50$ \\
\hline NC & 4,105 & 244 & 472 & 127 & 101.8 & $\$ 31.05$ \\
\hline $\mathrm{NH}$ & 478 & 28 & 472 & 127 & 101.8 & $\$ 49.43$ \\
\hline $\mathrm{NJ}$ & 324 & 19 & 494 & 133 & 106.6 & $\$ 31.05$ \\
\hline$N Y$ & 809 & 48 & 991 & 267 & 213.7 & $\$ 55.74$ \\
\hline $\mathrm{OH}$ & 716 & 43 & 710 & 191 & 153.1 & $\$ 9.68$ \\
\hline $\mathrm{OK}$ & 798 & 47 & 181 & 49 & 39.0 & $\$ 32.21$ \\
\hline OR & 3,640 & 217 & 725 & 195 & 156.4 & $\$ 27.99$ \\
\hline PA & 1,394 & 83 & 88 & 24 & 18.9 & $\$ 51.52$ \\
\hline SC & 4,299 & 256 & 236 & 64 & 50.9 & $\$ 32.27$ \\
\hline TN & 2,580 & 154 & 599 & 161 & 129.1 & $\$ 30.00$ \\
\hline $\mathrm{TX}$ & 2,658 & 158 & 140 & 38 & 30.2 & $\$ 11.44$ \\
\hline VA & 3,628 & 216 & 420 & 113 & 90.5 & $\$ 34.50$ \\
\hline $\mathrm{VT}$ & 139 & 37 & 139 & 37 & 30.0 & $\$ 32.21$ \\
\hline WA & 5,765 & 343 & 615 & 166 & 132.7 & $\$ 22.36$ \\
\hline W/I & 2,835 & 169 & 1,455 & 392 & 313.7 & $\$ 30.43$ \\
\hline WV & 364 & 22 & 364 & 98 & 78.5 & $\$ 32.21$ \\
\hline Total/Avg & 82,290 & 4,981 & 15,574 & 4,197 & $3,357.8$ & $\$ 32.21$ \\
\hline
\end{tabular}

'Source: Dyer (1997)

${ }^{2}$ Source: Chartwell Information Publishers Inc. (1997) 


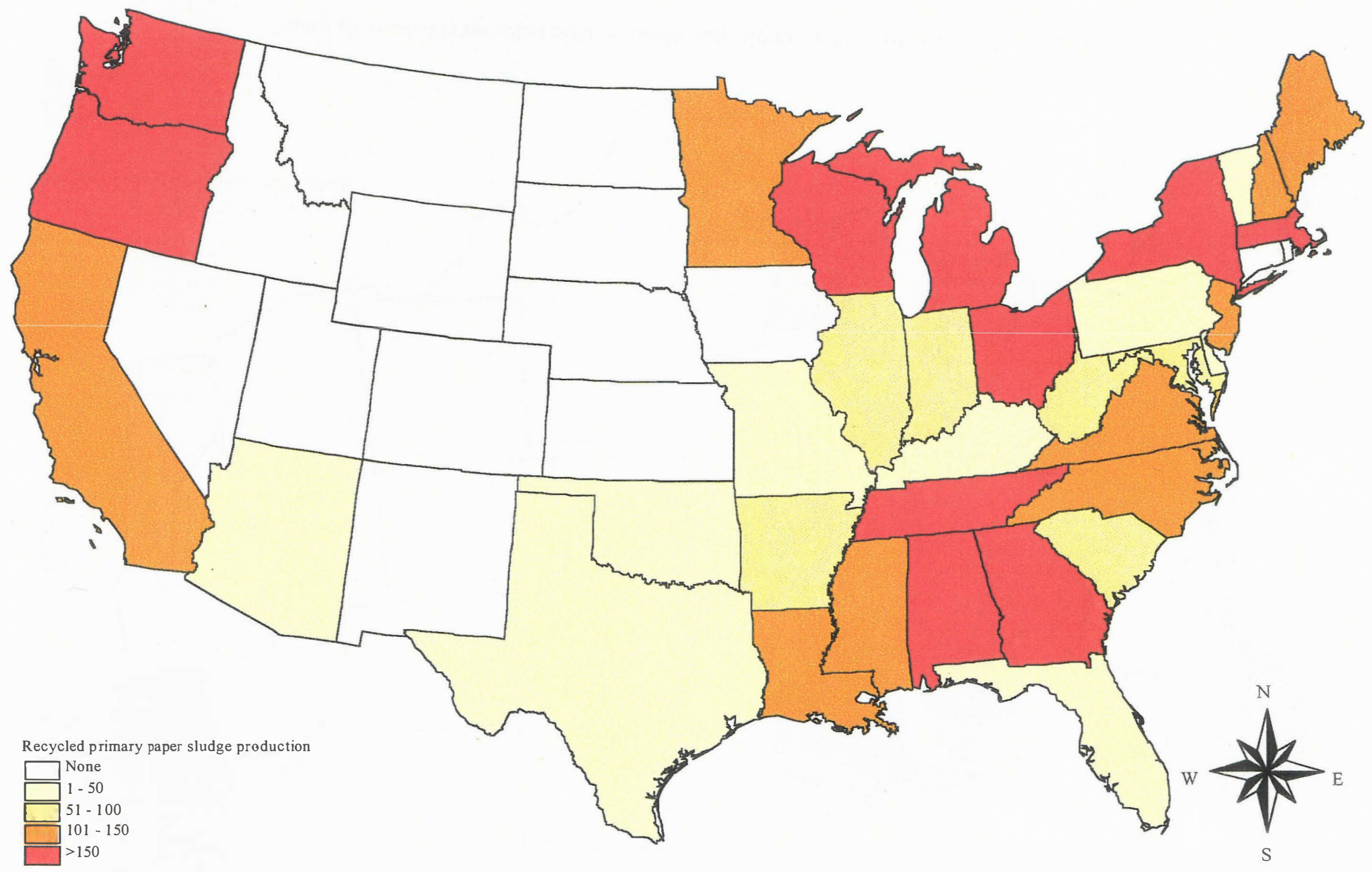

Figure 25. Total recycled primary paper pulp sludge production in 1996 (thousand dry tons/year) 


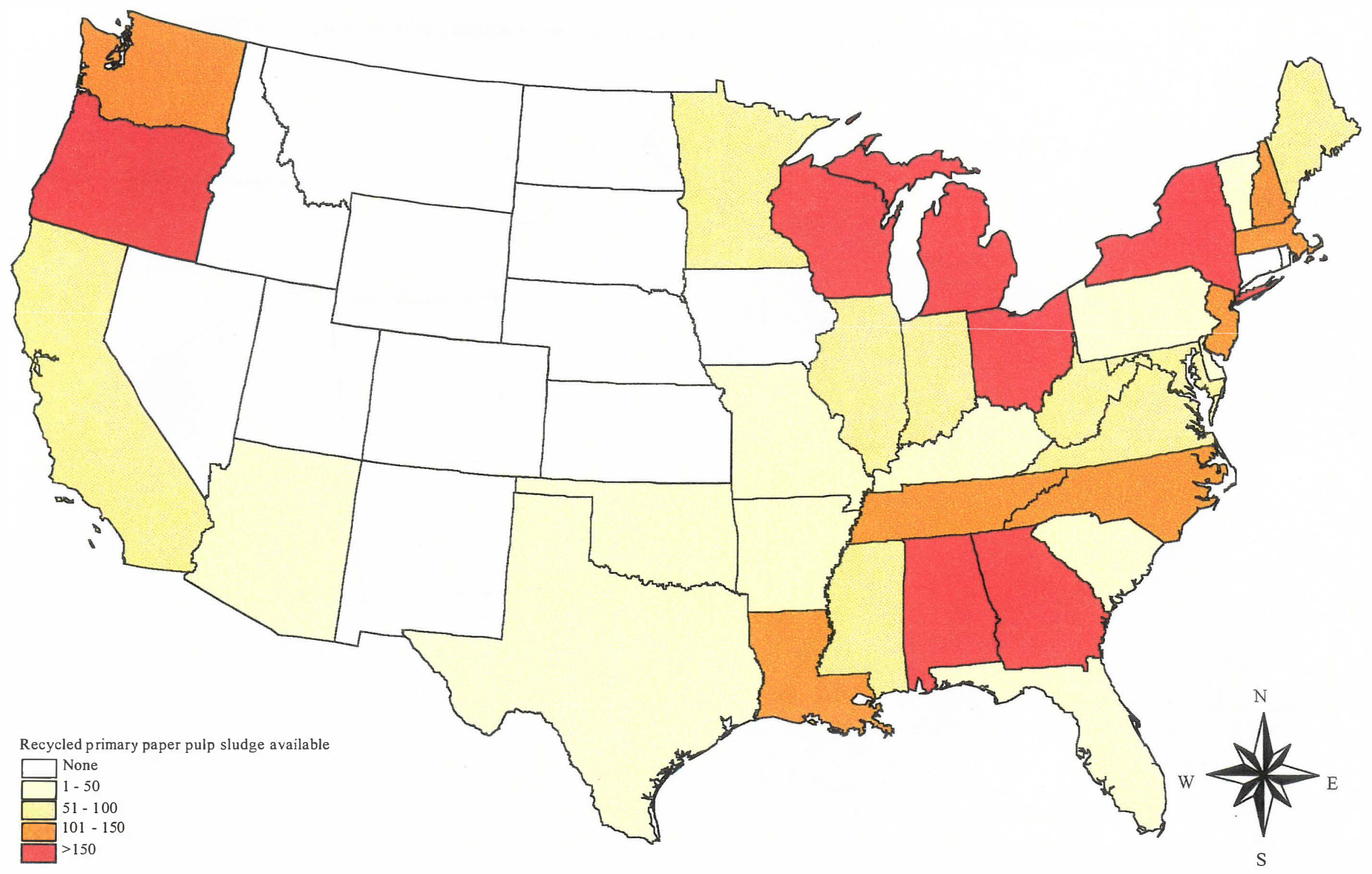

Figure 26. Available recycled primary paper pulp sludge in 1996 (thousand dry tons/year) 


\section{Spent Brewers Grains}

This residue category is composed of spent grains from the brewing processes of beer and malt beverage manufacturers. In the brewing process, cereal grains, along with malt and hops, are processed to remove fermentable sugars and flavoring. The grains used are primarily barley, corn, and rice. In the brewing industry other by-products are derived in smaller quantities from the malting and barley malt drying processes, and grain cleaning operations. This report focuses on spent cereal grains used in brewing. These residues are currently used in dairy cow, beef cattle, and poultry feed supplements.

\section{Data Sources and Methodology}

The Institute for Brewing Studies (1996) North American Brewer's Resource Directory provided contacts, phone numbers, and production capacities for breweries in the United States and Canada. These data, compiled for all breweries on a state level, were used to estimate spent grain production. Beer capacities were converted to residue quantities using a conversion factor of 0.003 dry tons/barrel of beer produced (WRBEP 1991). Data reported are from 1996, although some may not be updated.

Breweries were classified into size classes in this directory. Table 22 shows the volume range for these classes. All large breweries for which capacities were not reported (a total of seven) were contacted for their information. Seven of 12 regional breweries for which capacities were not reported were contacted. The remaining regional breweries that were not contacted were shut down, had disconnected telephone numbers, or did not participate despite numerous attempts. A large number of brewpubs and microbreweries did not report capacity data. For these breweries, statewide average capacities (within brewery size classes for each state) were used to adjust total brewery capacity to account for the missing capacities. The USDA reported current spent grain prices for a number of spot markets. Industry representatives were contacted for additional price information.

Table 22. Brewery production capacity classes

\begin{tabular}{|c|c|c|c|c|}
\hline & \multicolumn{4}{|c|}{ 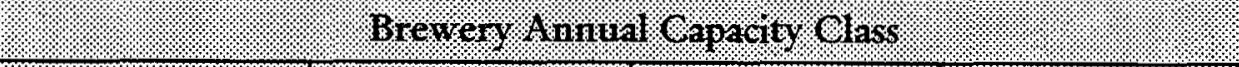 } \\
\hline & Brewpubs & Mrorolbreneries & 19egronal & large \\
\hline $\begin{array}{l}\text { Capacity range } \\
\text { (barrels) }\end{array}$ & $\begin{array}{l}>50 \% \text { consumed } \\
\text { on site }\end{array}$ & $<15,000$ barrels & $\begin{array}{l}>15,000 \text { and } \\
<500,000 \\
\text { barrels }\end{array}$ & $>500,000$ barrels \\
\hline
\end{tabular}

Source: Institute for Brewing Studies (1996)

\section{Results and Discussion}

Spent grains are produced mainly by larger brewers; $97 \%$ of total residue capacity comes from breweries classified as "large" (Table 23). Prices for brewers spent grain vary regionally and annually with the price of feed grains and with brewery production (Chandler 1997). As with corn fiber residues, spent grains from brewing operations are an established commodity. In theory, all spent grain production could be available for ethanol production given a competitive price. If the carbohydrates can be converted to ethanol and the protein retained and sold after ethanol extraction, the high feedstock price may not be a problem. 
Given the high value of brewers grains as animal feed (Table 24), spent grains are not likely to be an economically viable feedstock for ethanol production.

Table 23. 1996 beer and annual spent grain production among brewery sizes for the United States

\begin{tabular}{|c|c|c|c|}
\hline 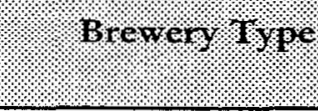 & (6raratit). & riestidier toris) & 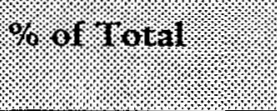 \\
\hline Brewpubs & 357,431 & 1,162 & $0.1 \%$ \\
\hline Microbreweries & 764,768 & 2,486 & $0.3 \%$ \\
\hline Regional & $7,325,300$ & 23,234 & $2.6 \%$ \\
\hline Large & $276,150,000$ & 886,238 & $97.0 \%$ \\
\hline Totals & $284,597,499$ & 913,120 & $100.0 \%$ \\
\hline
\end{tabular}

Source: Institute for Brewing Studies (1996)

${ }^{1}$ Residue production figures are as reported, not including adjustments for non-reported figures. Adjustments for non-reporting raise total residue production to slightly more than 1 million dry tons/year.

Table 24. 1996 spent brewing grain prices by state (\$/dry ton)

\begin{tabular}{|c|c|c|c|}
\hline 1018140 & Iraiana & Men 1041 & YIentiesser \\
\hline$\$ 117.00$ & $\$ 151.37$ & $\$ 130.00$ & $\$ 125.00$ \\
\hline
\end{tabular}

Source: Van Dyke (1997)

Some variability may be expected for the amount of residue produced according to the style of beer and the size of the brewery. However, numerous contacts to brewmasters indicated that variability was small, and not likely to affect the ranking of states based on their residue potential.

Spent brewing grains are widely distributed across the United States (Figure 27). The largest producers include Wisconsin, Colorado, California, and Texas. The total quantity of spent grains produced by state is contained in Table 25 . Approximately $60 \%$ of wet brewers grains are sold wet to dairy producers (Chandler 1992). Marketing of wet brewing grain is concentrated in areas close to breweries. The other $40 \%$ is dried and pelletized for less costly transportation to purchasers or exporters (Chandler 1992). The two major variables determining product value are percent dry matter and protein content. Protein content depends on the type of beer produced. Heavy beer has a corn or rice adjunct along with a barley component that gives them a protein content of approximately $30 \%$; light beers with a barley malt and sugar/syrup adjunct have a protein content of 22\%-24\% (Chandler 1992). The trend in brewing production demonstrates a long run annual growth rate of approximately $2 \%$ annually (Chandler 1992).

Using average statewide production capacities for brewpubs and microbreweries to adjust the reported brewery capacity may have resulted in an inaccurate representation of the quantity of spent grains from these brewery classes. However, the impact of this error source is rather small because of their small contribution to total production capacity. Brewpubs and microbreweries make up a very small proportion of total residue production $(0.4 \%)$. 
Table 25. Spent brewers grain adjusted annual quantity estimates

\begin{tabular}{|c|c|c|c|}
\hline St: & 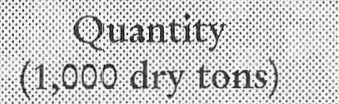 & Staiter & ( \\
\hline $\mathrm{AL}$ & 0.1 & NC & 44.0 \\
\hline $\mathrm{AR}$ & 0.1 & ND & - \\
\hline $\mathrm{AZ}$ & 0.1 & $\mathrm{NE}$ & 0.1 \\
\hline CA & 86.0 & $\mathrm{NH}$ & 10.5 \\
\hline $\mathrm{CO}$ & 102.1 & $\mathrm{NJ}$ & 32.2 \\
\hline $\mathrm{CT}$ & 0.1 & NM & 0.1 \\
\hline $\mathrm{DE}$ & - & NV & 0.1 \\
\hline FL & 37.7 & NY & 59.4 \\
\hline GA & 48.1 & $\mathrm{OH}$ & 46.6 \\
\hline IA & 0.1 & OK & 0.1 \\
\hline ID & 0.1 & OR & 27.1 \\
\hline IL & 0.4 & PA & 15.1 \\
\hline IN & 4.0 & RI & 0.1 \\
\hline $\mathrm{KS}$ & 0.1 & SC & 0.1 \\
\hline KY & 0.1 & $\mathrm{SD}$ & 0.1 \\
\hline LA & 1.1 & TN & 16.4 \\
\hline MA & 0.4 & $\mathrm{TX}$ & 77.0 \\
\hline $\mathrm{MD}$ & 25.6 & UT & 0.2 \\
\hline $\mathrm{ME}$ & 0.4 & VA & 60.0 \\
\hline MI & 59.4 & VT & 0.3 \\
\hline $\mathrm{MN}$ & 23.4 & WA & 30.9 \\
\hline MO & 44.4 & WI & 31.1 \\
\hline MS & - & WV & 0.1 \\
\hline $\mathrm{MT}$ & 0.1 & WY & 0.1 \\
\hline & & Total & 885.6 \\
\hline
\end{tabular}

Source: Institute for Brewing Studies (1996) 


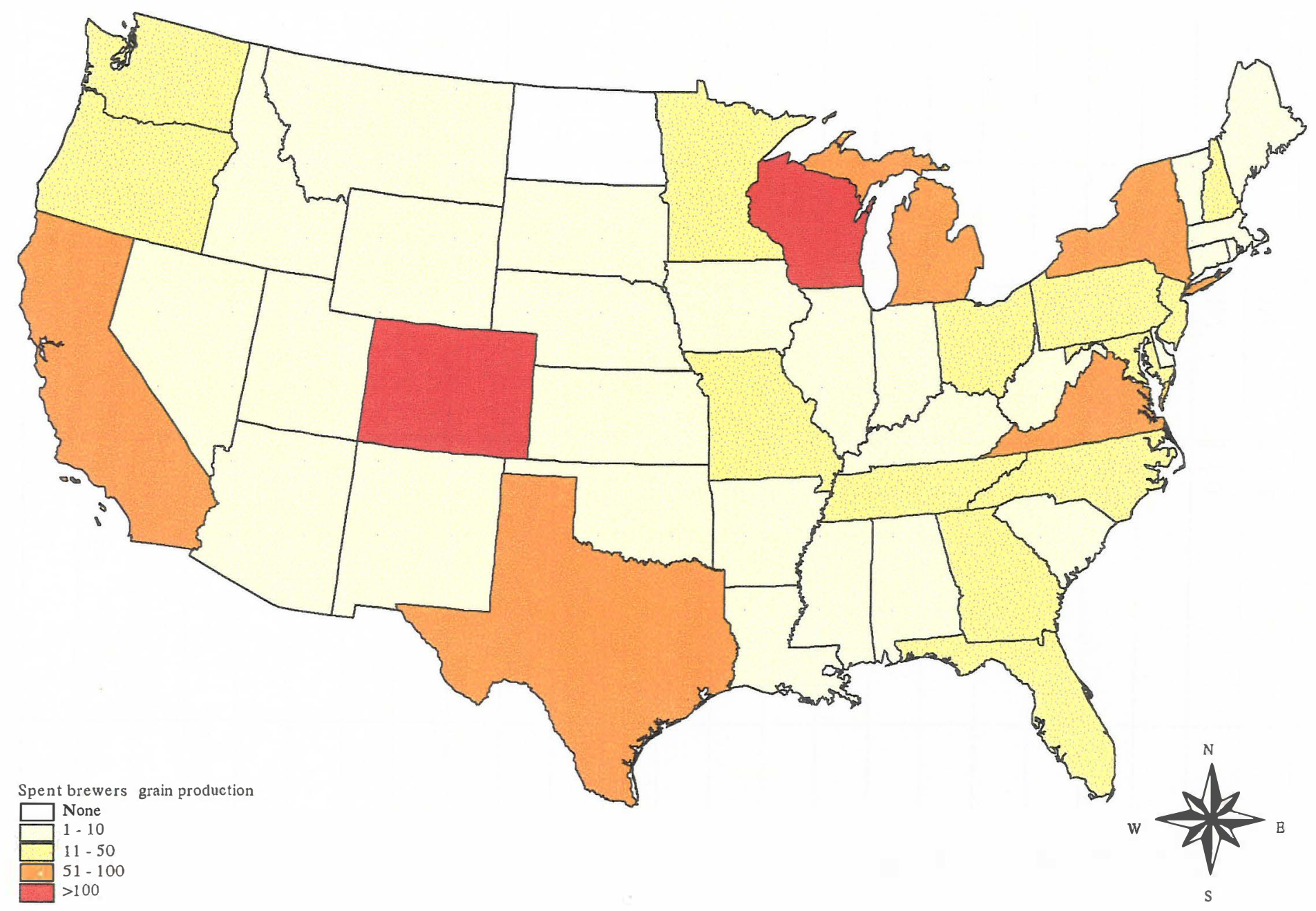

Figure 27. Total spent brewers grain production in 1996 (1,000 dry tons/year) 


\section{Sugarcane Bagasse}

Sugarcane bagasse consists of dry pulp left over after sugarcane is processed to produced sugar.

\section{Data Sources and Methodology}

The total quantity of sugarcane bagasse was estimated to be the same as for agricultural crop residues; namely, a constant residue yield per bushel of harvested crop. Although sugarcane bagasse is a food processing residue, this estimation method is reasonable because crop yields already account for harvesting losses. Average bagasse yields per ton of sugarcane produced are given in Table 26. The six-carbon sugar (glucose, galactose, and mannose) content of bagasse is $41 \%$; the five-carbon sugar (xylose and arabinose) content is $23 \%$. The quantity of bagasse produced varies, however, with plant variety, climate, soil conditions, cultivation procedures, and harvesting practices.

Table 26. Sugarcane bagasse technically and economically viable yields, and residue production per unit crop yield

\begin{tabular}{|c|c|c|}
\hline Iechnically nemionablile & 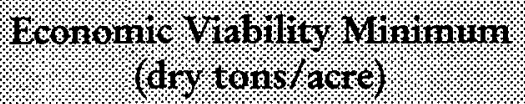 & Brgasse/vir. \\
\hline $100 \%$ of residue & 1.0 & $0.179^{1}$ \\
\hline
\end{tabular}

${ }^{1}$ Source: Worley and Cundiff (1992)

\section{Results and Discussion}

Figure 28 shows total bagasse production by state. Numeric data for sugarcane bagasse production are shown in Table 27. Bagasse is concentrated in the Mississippi Delta States, Florida, and Hawaii.

Table 27. Sugarcane bagasse estimates for 1996

\begin{tabular}{|c|c|c|c|}
\hline Strater & 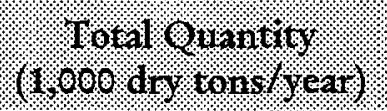 & 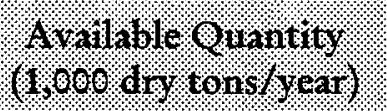 & 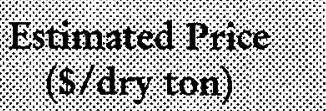 \\
\hline FL & $1,797.8$ & 359.6 & $\$ 5.50$ \\
\hline $\mathrm{HI}$ & 600.4 & 120.1 & $\$ 6.39$ \\
\hline LA & $1,048.2$ & 209.6 & $\$ 5.70$ \\
\hline TX & 96.3 & 19.3 & $\$ 5.76$ \\
\hline Total/Average & $3,542.7$ & 708.6 & $\$ 5.84$ \\
\hline
\end{tabular}

Availability of bagasse is $20 \%$ of total production (Gatto 1997). Most is combusted to provide energy and heat used to process sugarcane. Bagasse is generally available during the summer in the conterminous United States, although that period may be extended on Hawaii. Bagasse is traditionally burned in small steam-turbine cogenera- tion systems to supply on-site steam and electricity needs. Typical conversion 
rates are $20 \mathrm{kWh}$ of electricity and 200-300 pounds of low-pressure steam per ton of cane processed. Most electricity is used on site, although some plants sell back to the local utility. A small amount of bagasse is used to produce structural board materials. The quantity used for this purpose could not be obtained because that information is proprietary.

Sugarcane bagasse is seldom sold, although it may occasionally be stockpiled when electricity market conditions do not favor the sale of excess generating capacity to the local utility. Considerable attention has been given to bagasse use for purposes other than energy because of problems associated with long-term storage of bagasse such as nitrogenous leachates from storage areas, which may necessitate additional investment in storage facilities to comply with environmental regulations (Legendere 1997).

Commercial institutions have already targeted bagasse as an ethanol feedstock. BC International Corporation (BCI) has begun a cost-shared partnership to demonstrate biomass-to-ethanol technology in a commercial plant in Jennings, Louisiana. DOE's Office of Transportation Technology (OTT) reported that the plant has a startup production rate of 10 million gallons annually, with an eventual maximum annual production rate of 25 million gallons. The plant will also be able to convert rice straw and sawdust. The overall investment is $\$ 40$ million, of which approximately $\$ 6$ million is cost-shared (DOE OTT 1997).

There is no established market price for bagasse, and information required to estimate the cost to collect and store this feedstock is not readily available. Costs associated with sugarcane processing that are attributable to bagasse include collection and storage costs. Because bagasse is a coproduct, these costs are unavoidable and are typically considered part of the processing operation by sugarcane processors. Given an alternative market, a proportion of sugarcane bagasse may be available for ethanol production if the price outweighs the current value of end products derived from bagasse.

A price estimate of the value of sugarcane bagasse may be made based on the wholesale electricity price, the Btu content of the fuel, and the efficiency of combustion processes used to generate electricity from bagasse. Table 27 shows estimated state level values of sugarcane bagasse. These values are break-even prices for bagasse purchased as an ethanol feedstock to compete with the value of steam and electricity obtained from bagasse combustion. Price calculations assumed energy and steam yields of $20 \mathrm{kWh}$ and 300 pounds of low-pressure steam per dry ton of sugarcane bagasse (Legendere 1997). Values for electricity were for commercial users and piped steam values were for commercial heating purposes. Piped steam prices were reported for Baltimore, Maryland. In-state values were not available for piped steam. Electricity prices were for generators located within each bagasse producing state, which produced the variation in bagasse costs among the states (Randazzo 1997). As can be seen, if used for ethanol the major cost for bagasse would be transportation from the producer, which can be negated for on-site production facilities. If electricity prices are high, ethanol is less feasible because sugarcane processors will continue to generate their own power to offset higher electricity prices. 


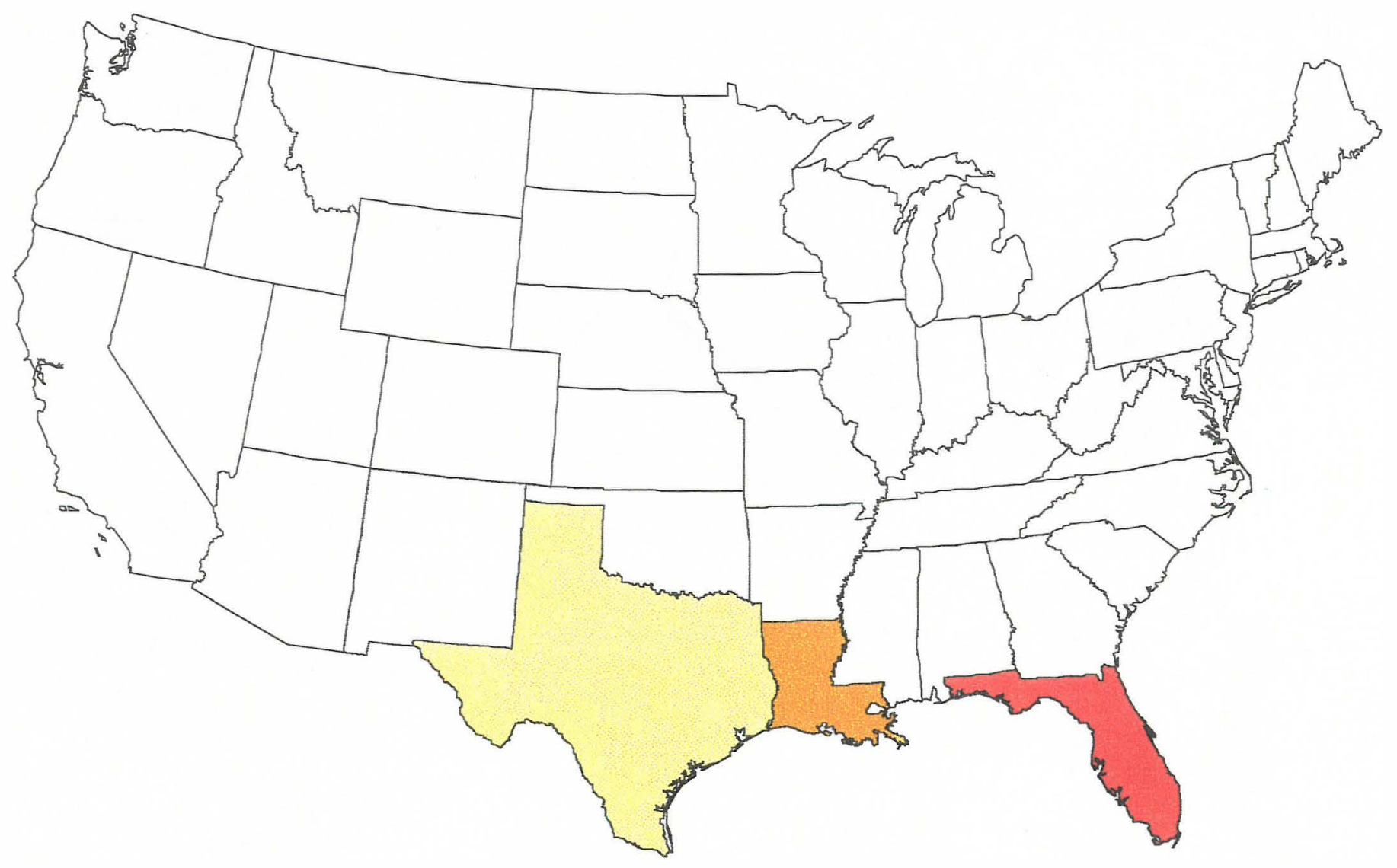

Hawaii
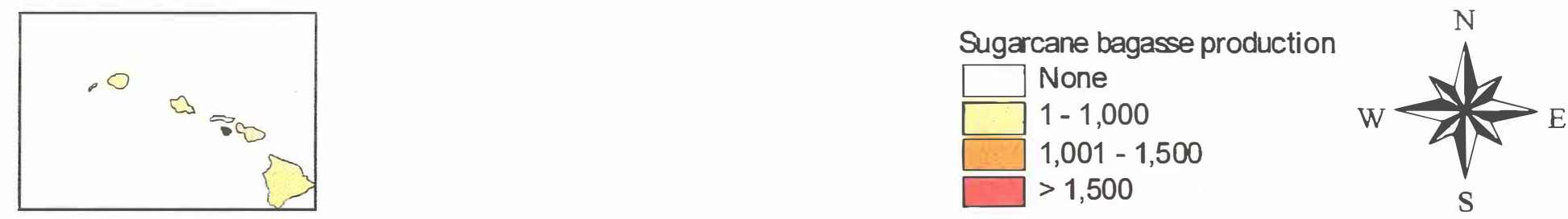

Figure 28. Total sugarcane bagasse production in 1996 (thousand dry tons/year) (Hawaii not shown to scale.) 


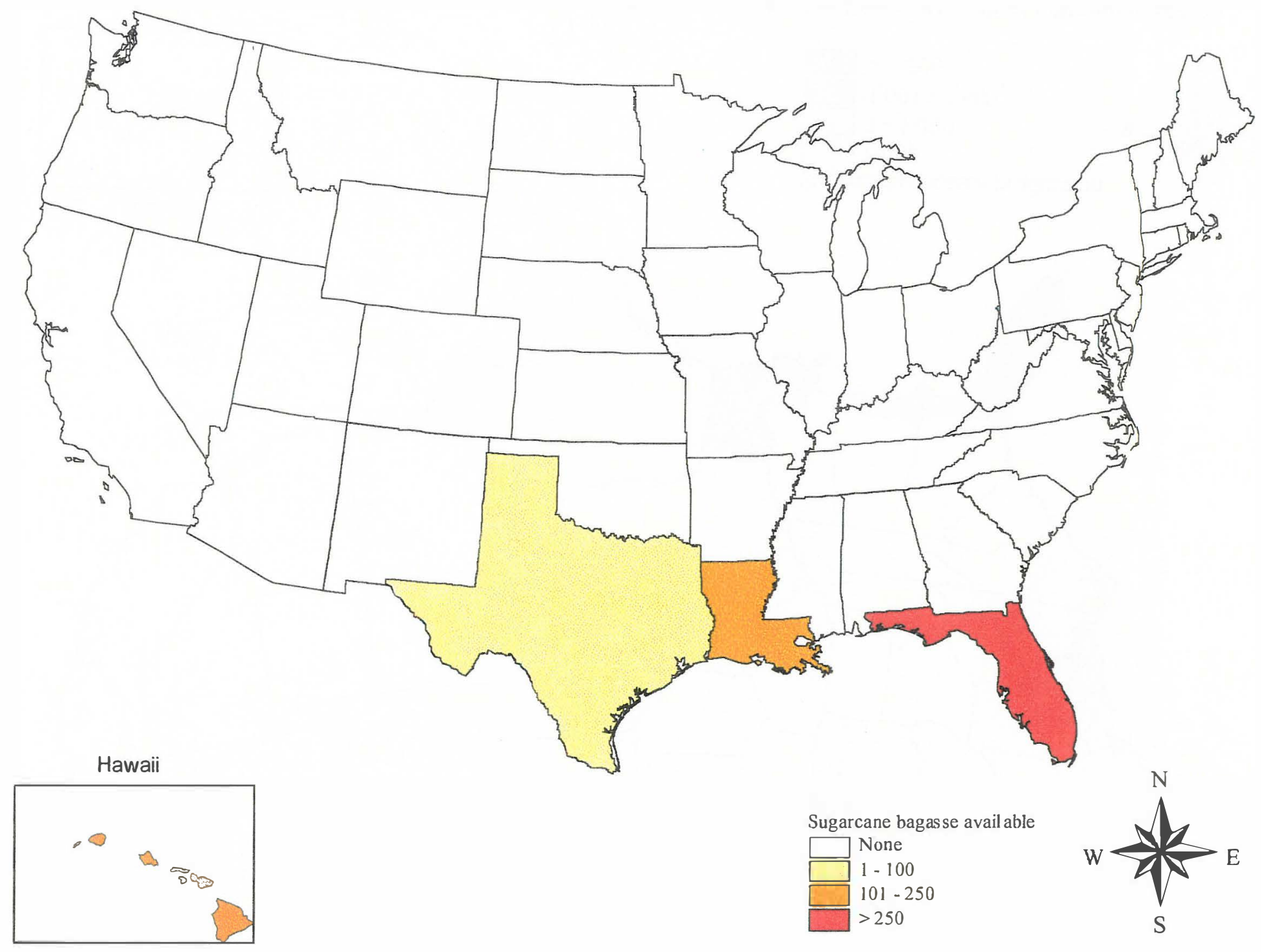

Figure 29. Available sugarcane bagasse in 1996 (thousand dry tons/year) (Hawaii not shown to scale.) 


\section{Wastepaper}

Two types of recovered wastepaper-newsprint and mixed office papers-were assessed in this study. All grades of newsprint, along with groundwood inserts, were included. Mixed office papers include all types of recycled office paper.

\section{Data Sources and Methodology}

This section outlines the methods used to estimate the quantity, availability, and price of newsprint and mixed office wastepaper in the United States. Paper, MSW, and recycling industry trade associations, as well as government agencies such as the EPA and the U.S. Bureau of the Census were contacted for information regarding wastepaper quantities generated and recovered state-by-state. According to Franklin \& Associates Ltd. (1997), for the United States as a whole newsprint represented in 1995 approximately $10.4 \%$ of recovered MSW by weight and mixed office paper for $5.4 \%$. State-by-state data on generated and recycled MSW were obtained from Biocycle (Goldstein and Glenn 1997). Multiplying state-recovered MSW quantities (Biocycle) by national Franklin Associates MSW newsprint and office paper composition percentages allowed for estimates of state-level quantities of recovered newsprint and mixed office paper.

Market prices for recovered papers were obtained from Official Board Markets (OBM), a weekly newsletter that provides transacted paper stock prices for nine regional markets. $O B M$ provides high and low prices for mixed papers, number six newsprint, and number eight newsprint. The high and low prices from one issue per month from July 1996 through June 1997 were averaged for each market area (Advanstar 19961997). The prices for number six and number eight newsprint were averaged because the estimated newsprint quantities contain all newsprint grades.

\section{Results and Discussion}

State MSW production data were based on state agency surveys and represent the most complete information available from all sources. However, many states did not have 1996 data available. Arizona, Arkansas, Colorado, Florida, Idaho, Kansas, Kentucky, Maine, Maryland, Minnesota, Missouri, Montana, Nebraska, New Hampshire, New Jersey, New Mexico, New York, Ohio, Oregon, Pennsylvania, Tennessee, Texas, Virginia, and Wisconsin reported data from 1990 to 1995.

National MSW, newsprint, and office paper recovery rates are adequate for national information but do not necessarily represent proportions generated and recovered by each state. There are regional variations on the types and quantities of MSW recovered because of local recycling programs, recovered materials prices, landfill space availability, and state regulations.

Recovered newsprint is used for paper and paperboard feedstock (65\%), molded pulp (16\%), and exported (19\%) (American Forest and Paper Association 1996). Recovered mixed office paper is also a paper and paperboard feedstock. Nationally, 51\% of newsprint and 44\% of office papers were recovered in 1995 (Franklin Associates, Ltd. 1997).

Figures 30 and 31 show the estimated total and available newsprint by state. Total newsprint is the estimated total quantity generated. Available newsprint is that which is currently recovered. Newsprint production, as with all paper products, is generally higher in states with larger populations. Key states for generating and recovering newsprint include California, Florida, New York, and Texas (Table 28). Figures 
32 and 33 depict total and available (defined for newsprint) mixed office paper by state. Geographic trends in mixed office paper reflect those of newsprint.

Paper availability is based on current recovery rates, which are higher for newsprint and office paper than for other paper products such as books, telephone directories, third class mail, and magazines (Goldstein 1997). Overall, U.S. paper recovery rates are slightly higher than $44 \%$. The American Forest and Paper Association (1996) set a goal in 1993 to meet a 50\% paper recovery rate by the year 2000. If newsprint and mixed office paper recovery increase along with other sectors, the potential feedstock supply for ethanol will probably increase as well. The maximum theoretical recovery rate for paper and paper is $80 \%$ (Ince 1994).

Table 28 shows total MSW, newsprint, and mixed office paper generation and recovery by state, and Table 29 shows average prices for mixed paper and newsprint for nine regions.

Mixed office paper can be obtained for a negative price in the Northeast, which makes that area a viable candidate for ethanol production from mixed office paper (Table 29). Prices are positive in the West, but significantly lower than in the Midwest and Lake States. Mixed office paper costs less than newsprint in the West. Newsprint is a higher-cost feedstock than mixed office paper in all regions except the Southwest (Table 29). Export markets for newsprint elevate prices for newsprint above those of mixed office paper in West Coast states. Newsprint prices are lower in the Northeast because of high production and landfill costs. In the Midwest, Chicago is a point market for low newsprint costs. 
Table 28. Generated and recovered MSW, newsprint, and mixed office paper (1,000 dry tons/year)

\begin{tabular}{|c|c|c|c|c|c|c|}
\hline 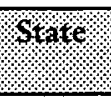 & 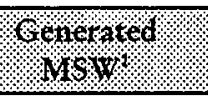 & regres & 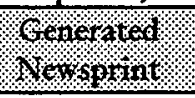 & Herspresint. & Gencrated & 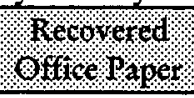 \\
\hline $\mathrm{Al}$ & 5,471 & 1,094 & 253.3 & 135.5 & 132.3 & 58.6 \\
\hline $\mathrm{AR}$ & 2,154 & 775 & 179.5 & 96.0 & 93.8 & 41.5 \\
\hline $\mathrm{AZ}$ & 4,886 & 684 & 158.3 & 84.7 & 82.7 & 36.6 \\
\hline $\mathrm{CA}$ & 44,000 & 11,440 & $2,648.2$ & $1,416.8$ & $1,383.1$ & 612.7 \\
\hline $\mathrm{CO}$ & 2,811 & 478 & 110.6 & 59.2 & 57.8 & 25.6 \\
\hline $\mathrm{CT}$ & 2,951 & 679 & 157.1 & 84.1 & 82.1 & 36.4 \\
\hline $\mathrm{DE}$ & 987 & 207 & 48.0 & 25.7 & 25.1 & 11.1 \\
\hline FL & 24,312 & 9,725 & $2,251.1$ & $1,204.4$ & $1,175.7$ & 520.8 \\
\hline $\mathrm{GA}$ & 9,872 & 3,258 & 754.1 & 403.5 & 393.9 & 174.5 \\
\hline IA & 3,237 & 971 & 224.8 & 120.3 & 117.4 & 52.0 \\
\hline ID & 886 & 248 & 57.4 & 30.7 & 30.0 & 13.3 \\
\hline IL & 13,400 & 3,082 & 713.4 & 381.7 & 372.6 & 165.1 \\
\hline IN & 5,800 & 1,334 & 308.8 & 165.2 & 161.3 & 71.4 \\
\hline $\mathrm{KS}$ & 4,250 & 468 & 108.2 & 57.9 & 56.5 & 25.0 \\
\hline $\mathrm{KY}$ & 3,580 & 644 & 149.2 & 79.8 & 77.9 & 34.5 \\
\hline LA & 4,700 & 705 & 163.2 & 87.3 & 85.2 & 37.8 \\
\hline MA & 7,160 & 2,363 & 546.9 & 292.6 & 285.7 & 126.5 \\
\hline $\mathrm{MD}$ & 5,124 & 1,383 & 320.3 & 171.3 & 167.3 & 74.1 \\
\hline $\mathrm{ME}$ & 1,293 & 427 & 98.8 & 52.8 & 51.6 & 22.9 \\
\hline MI & 13,500 & 3,375 & 781.3 & 418.0 & 408.0 & 180.8 \\
\hline $\mathrm{MN}$ & 4,600 & 2,116 & 489.8 & 262.1 & 255.8 & 113.3 \\
\hline $\mathrm{MO}$ & 7,661 & 1,992 & 461.1 & 246.7 & 240.8 & 106.7 \\
\hline MS & 2,400 & 288 & 66.7 & 35.7 & 34.8 & 15.4 \\
\hline $\mathrm{MT}$ & 900 & 45 & 10.4 & 5.6 & 5.4 & 2.4 \\
\hline NC & 9,929 & 2,184 & 505.6 & 270.5 & 264.1 & 117.0 \\
\hline ND & 502 & 136 & 31.4 & 16.8 & 16.4 & 7.3 \\
\hline $\mathrm{NE}$ & 2,000 & 520 & 120.4 & 64.4 & 62.9 & 27.9 \\
\hline $\mathrm{NH}$ & 1,245 & 249 & 57.6 & 30.8 & 30.1 & 13.3 \\
\hline $\mathrm{NJ}$ & 9,320 & 4,008 & 927.7 & 496.3 & 484.5 & 214.6 \\
\hline NM & 1,396 & 168 & 38.8 & 20.7 & 20.3 & 9.0 \\
\hline NV & 3,267 & 392 & 90.8 & 48.6 & 47.4 & 21.0 \\
\hline $\mathrm{NY}$ & 26,800 & 8,576 & $1,985.2$ & $1,062.1$ & $1,036.8$ & 459.3 \\
\hline $\mathrm{OH}$ & 11,449 & 1,717 & 397.5 & 212.7 & 207.6 & 92.0 \\
\hline OK & 2,500 & 300 & 69.4 & 37.2 & 36.3 & 16.1 \\
\hline $\mathrm{OR}$ & 3,624 & 1,051 & 243.3 & 130.2 & 127.1 & 56.3 \\
\hline PA & 9,575 & 1,915 & 443.3 & 237.2 & 231.5 & 102.6 \\
\hline RI & 484 & 111 & 25.8 & 13.8 & 13.5 & 6.0 \\
\hline $\mathrm{SC}$ & 7,897 & 2,132 & 493.6 & 264.1 & 257.8 & 114.2 \\
\hline $\mathrm{SD}$ & 842 & 320 & 74.1 & 39.6 & 38.7 & 17.1 \\
\hline TN & 9,117 & 3,647 & 844.2 & 451.6 & 440.9 & 195.3 \\
\hline TX & 21,859 & 6,121 & $1,416.8$ & 758.0 & 740.0 & 327.8 \\
\hline UT & 2,996 & 569 & 131.8 & 70.5 & 68.8 & 30.5 \\
\hline VA & 8,649 & 3,027 & 700.7 & 374.9 & 366.0 & 162.1 \\
\hline VT & 600 & 180 & 41.7 & 22.3 & 21.8 & 9.6 \\
\hline WA & 6,643 & 2,591 & 599.7 & 320.8 & 313.2 & 138.8 \\
\hline WI & 5,434 & 2,174 & 503.2 & 269.2 & 262.8 & 116.4 \\
\hline WV & 2,000 & 260 & 60.2 & 32.2 & 31.4 & 13.9 \\
\hline WY & 530 & 21 & 4.9 & 2.6 & 2.6 & 1.1 \\
\hline Totals & 327,460 & 90,693 & 20,994 & 11,232 & 10,965 & 4,857 \\
\hline
\end{tabular}

'Sources: Goldstein (1997); Goldstein and Glenn (1997) 
Table 29. Average prices for mixed paper and newsprint

\begin{tabular}{|c|c|c|}
\hline Markst & 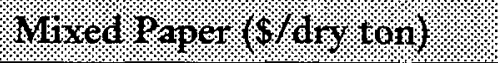 & 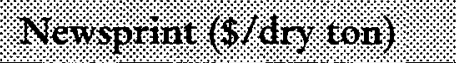 \\
\hline New England & $\$(2.08)$ & $\$ 3.33$ \\
\hline Buffalo, NY & $\$(\$ 2.08)$ & $\$ 3.75$ \\
\hline New York, NY & $\$(7.50)$ & $\$ 3.75$ \\
\hline Chicago, IL & $\$ 2.92$ & $\$ 10.00$ \\
\hline Southeast & $\$ 5.42$ & $\$ 16.04$ \\
\hline Southwest & $\$ 10.83$ & $\$ 16.46$ \\
\hline Los Angeles, CA & $\$ 2.92$ & $\$ 26.67$ \\
\hline San Francisco, CA & $\$ 2.50$ & $\$ 23.13$ \\
\hline Pacific Northwest & $\$ 5.83$ & $\$ 30.83$ \\
\hline Average & $\$ 2.08$ & $\$ 14.88$ \\
\hline
\end{tabular}

Source: Advanstar (1996-1997) 


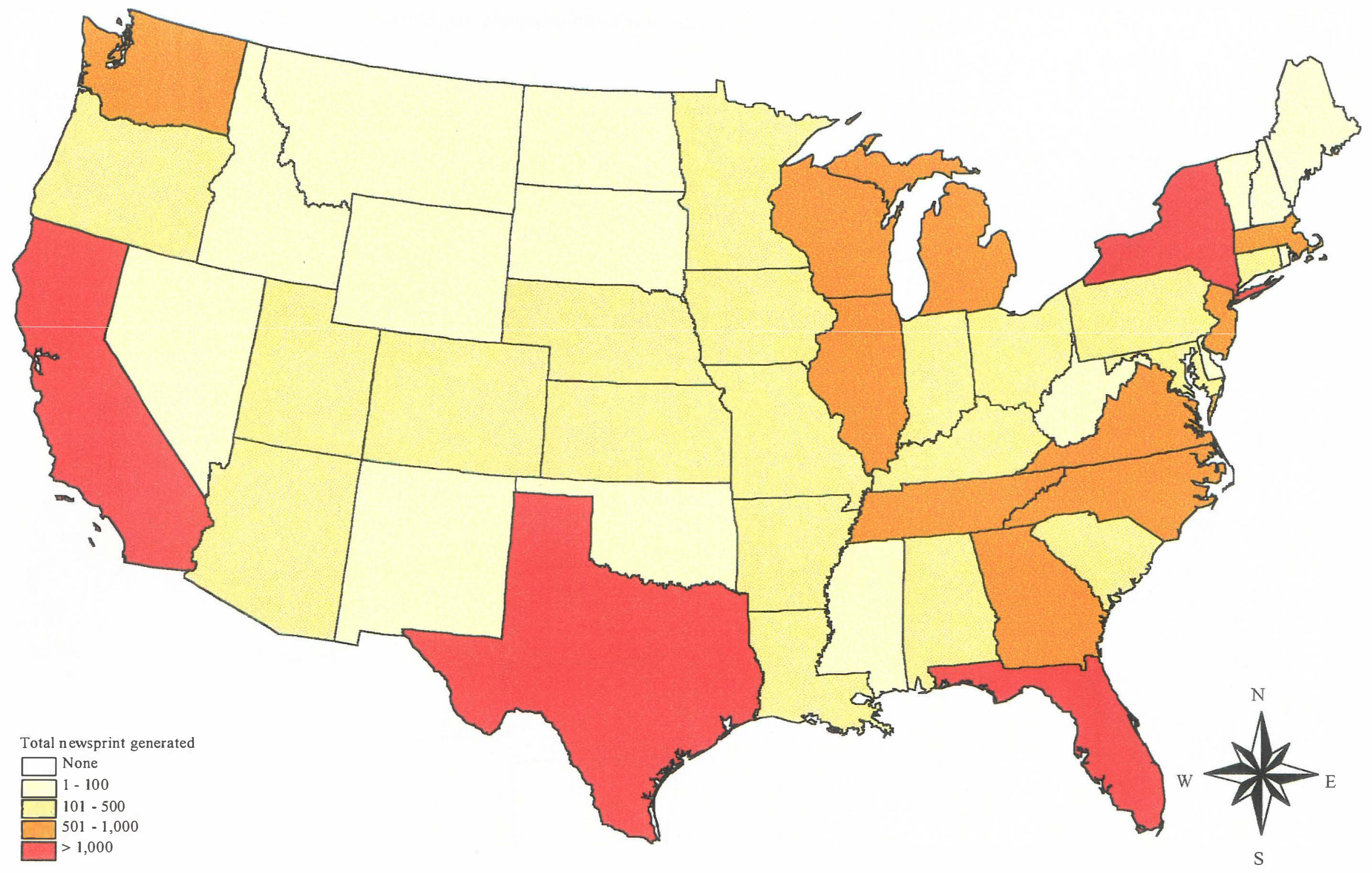

Figure 30. Total newsprint production in 1996 (thousand dry tons/year) 


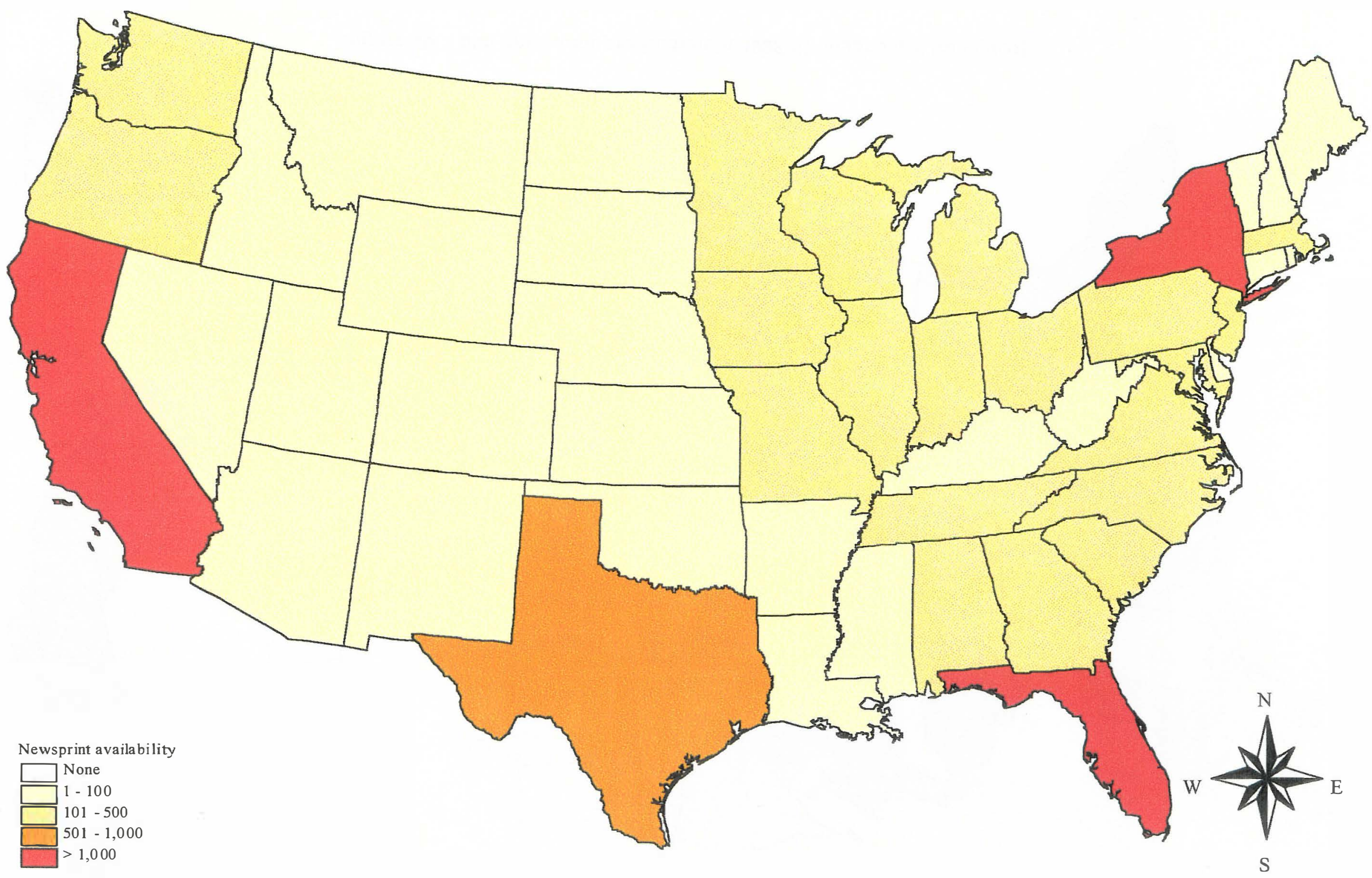

Figure 31. Available newsprint in 1996 (thousand dry tons/year) 


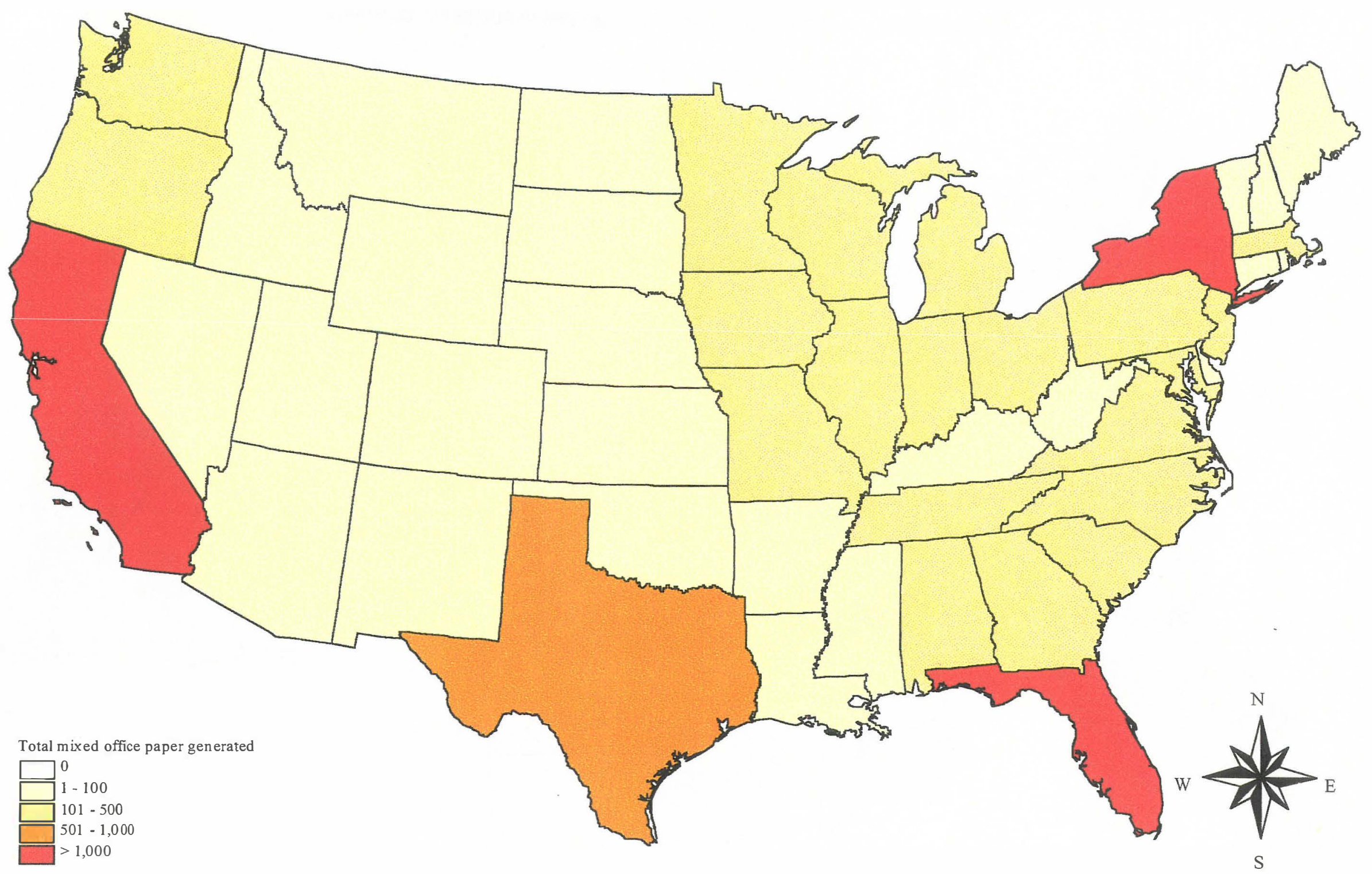

Figure 32. Total mixed office paper production in 1996 (thousand dry tons/year) 


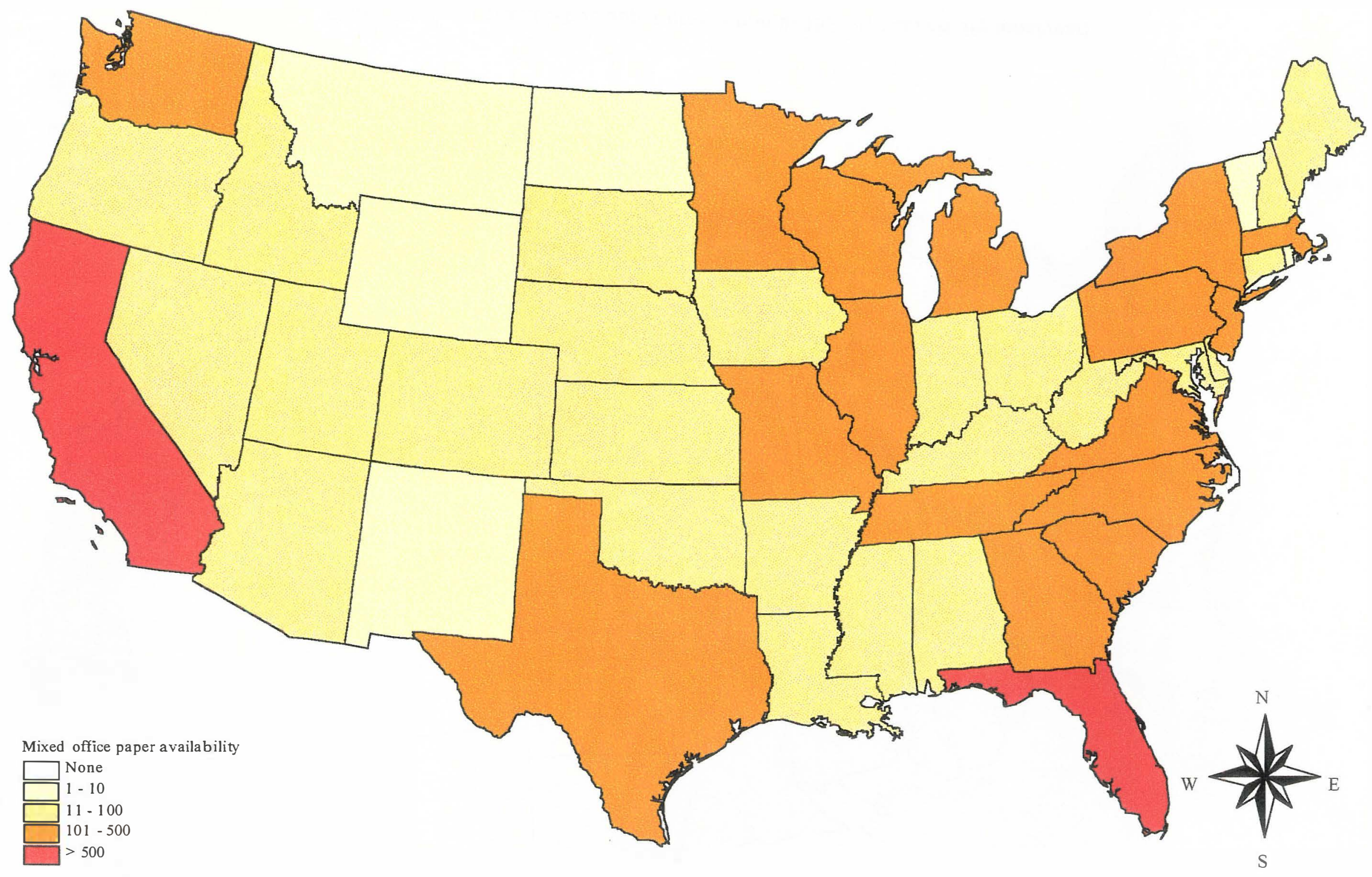

Figure 33. Available mixed office paper in 1996 (thousand dry tons/year) 


\section{Urban Tree Residue}

This section contains information on the production, distribution, competing uses, and availability of residues generated as a result of urban forestry and landscaping activities. UTR is defined as "green" material such as tree limbs, tops, brush, leaves, stumps, and grass clippings. Sources not considered to be UTR include construction and demolition debris, wooden pallets and reels, and residue from the secondary wood products industry (e.g., furniture makers).

In general, UTR consists of one or more of the following residue types:

$\begin{array}{ll}\text { Chips } & \text { All wood chips, including stump chips } \\ \text { Logs } & \text { Unchipped wood, usually with a diameter greater than } 8 \text { inches } \\ \text { Tops and Brush } & \text { Unchipped wood residue, other than logs } \\ \text { Mixed Wood } & \text { Combination of logs, whole tops, and brush } \\ \text { Leaves } & \text { Leaves resulting from seasonal leaf collection } \\ \text { Grass } & \text { Grass clippings from lawn mowing activities } \\ \text { Stumps } & \text { Pulled stumps only }\end{array}$

UTR generators encompass several commercial and governmental categories. Following are the main generator groups:

- Commercial tree care firms

- Municipal/county park and recreation departments

- Municipal tree care divisions

- County tree care divisions

- Electric utility power line maintenance operations

- Nurseries

- Landscape maintenance/landscapers

- Excavator/land clearance.

An additional group, orchards, is not included in the data presented here, but has the potential to be a significant contributor to the tree residue resource base.

The arboriculture and urban forestry industries represent a diverse collection of companies that serve national, regional, and niche markets. For example, three firms, Asplundh Tree Expert Company, Davey Tree Expert Company, and the F.A. Bartlett Tree Expert Company, serve corporate accounts and command a substantial market share in the commercial tree care sector. These firms operate nationally with moderate to large offices located throughout the country. In addition to these three companies, the tree care industry is largely composed of small firms and municipal organizations. These smaller organizations operate very differently from the large firms, often with little specialization. Further, niche activities such as orchard trimming and stump removal or land clearance generate considerable residue but are serviced by distinct firms.

\section{Data Sources and Methodology}

Data and information used in this section were obtained from a national survey of the urban forestry and landscaping industry (NEOS Corporation 1994), and sponsored by the International Society of Arboriculture Research Trust, the National Arborist Foundation, and the Allegheny Power Service Corporation. The 1994 study was the first (and only) nationwide study of the quantity and quality of UTR and landscape residue. Other studies and resource assessments have been conducted, but all at the local level. All data and values presented in this section were obtained from the NEOS 1994 study. Additional data on wood waste tip fees were obtained from Chartwell Information Publishers, Inc. 
As shown in Table 30, the national UTR survey was sent to nearly 4,000 U.S. generators. More than 1,300 surveys were returned, representing an overall response rate of $34 \%$. We did not independently verify the returned surveys but relied on the information and data as provided by the respondents.

Table 30. National UTR survey results

\begin{tabular}{|c|c|c|c|}
\hline Generafor Grorro. & 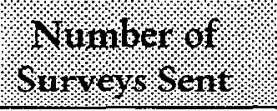 & Hefurstrover & 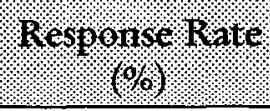 \\
\hline Commercial tree care & 2,227 & 638 & $28 \%$ \\
\hline Municipal/county park and recreation & 206 & 127 & $62 \%$ \\
\hline Municipal/county tree care division & 202 & 100 & $50 \%$ \\
\hline Electric utility line maintenance & 603 & 284 & $47 \%$ \\
\hline Orchard & 201 & 35 & $17 \%$ \\
\hline Landscape maintenance/nursery & 199 & 124 & $62 \%$ \\
\hline Excavator/land clearance & 190 & 21 & $11 \%$ \\
\hline Total/Average & 3,878 & 1,330 & $34 \%$ \\
\hline
\end{tabular}

Source: NEOS Corp. (1994)

As anecdotal evidence suggested, the survey revealed a lack of knowledge by industry personnel on the actual volume and characteristics of the residues they generate. For example, more than $95 \%$ of the survey respondents provided information that was based on estimates rather than actual values.

In the 1994 study, the survey results were used to develop national estimates for annual production of UTR and landscape residues. The methodology used to scale up the survey data to national estimates followed accepted statistical procedures and is documented in the report. For the 1994 survey, UTR generation data were reported in cubic yards/year. For purposes of this report, the values have been converted from cubic yards to bone dry tons, using the conversion factors listed in Table 31.

Table 31. UTR conversion factors

\begin{tabular}{|c|c|c|}
\hline Yla $14 p e$ & 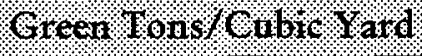 & 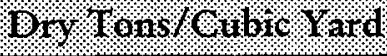 \\
\hline Leaves $^{1}$ & 0.18 & 0.14 \\
\hline Grass $^{1}$ & 0.18 & 0.14 \\
\hline Chips $^{2}$ & 0.30 & 0.24 \\
\hline $\operatorname{Logs}^{2}$ & 0.40 & 0.32 \\
\hline Tops/brush ${ }^{2}$ & 0.17 & 0.14 \\
\hline Mixed wood ${ }^{2}$ & 0.20 & 0.16 \\
\hline Stumps ${ }^{2}$ & 0.50 & 0.40 \\
\hline
\end{tabular}

OCRRA (1991)

${ }^{2}$ Fisher (1992) 
Another issue that must be considered is that the generation of UTR is highly sensitive to natural disaster events. Hurricanes, tornadoes, floods, snow, and hailstorms all can have significant impacts on UTR generation rates in localized areas over a short time. The 1994 study attempted to account for the impacts of natural disasters through a series of survey questions and through the analytic approach.

\section{Results and Discussion}

The total UTR production is estimated to be nearly 48,000,000 dry tons/year. Table 32 shows UTR production by state and residue type. As shown in Figure 34, nearly two-thirds of the residue produced is in chipped form, $20 \%$ is in log form, and $10 \%$ is mixed wood and tops/brush.

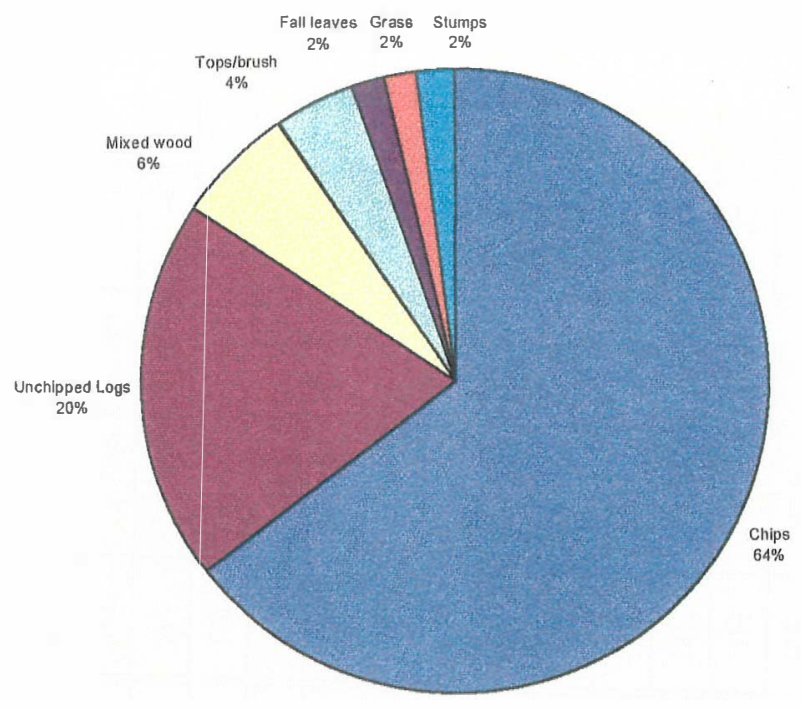

Figure 34. Breakdown of UTR types

Source: NEOS Corporation (1994)

Figure 35 shows residue production by generator group. Landscapers are the largest UTR source, followed by arborists, park departments, municipalities, utilities, and land clearance contracto's.

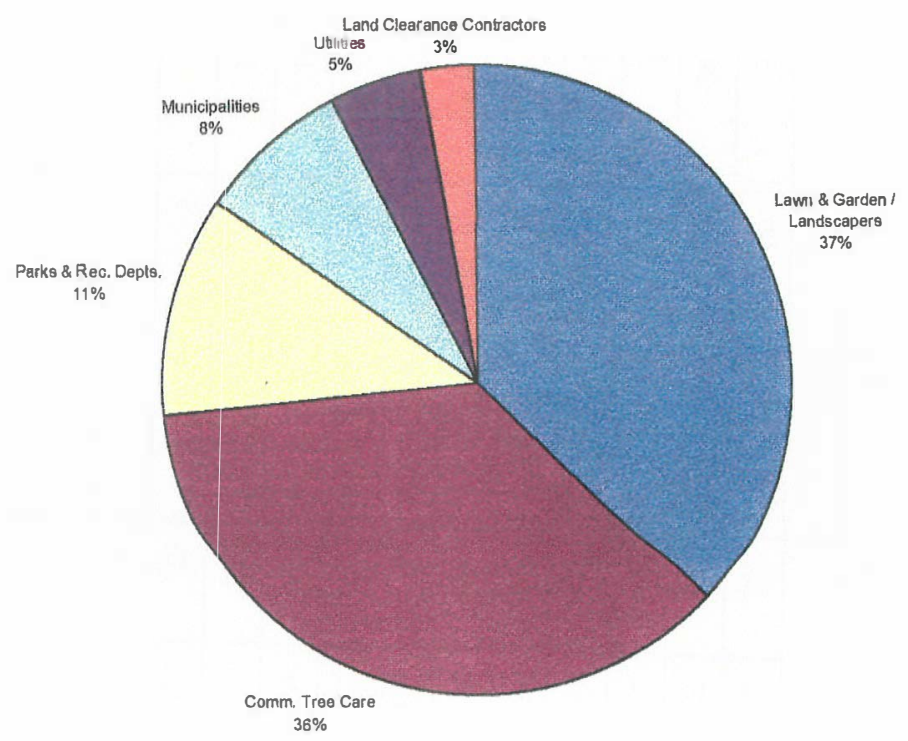

Figure 35. UTR production, by generator type

Source: NEOS Corporation (1994) 
Table 32. UTR 1993 annual production, by residue type (1,000 dry tons/year)

\begin{tabular}{|c|c|c|c|c|c|c|c|c|c|c|c|c|c|c|c|c|c|}
\hline State & Whips & 1000 & Bropstish & Mlloded & terves & Grass & Sturnps & Iotar & State & Chips & 1.085 & orops: & Whod & Leaves & Wr. & Sown & Total \\
\hline $\mathrm{AL}$ & 445 & 110 & 35 & 35 & 2 & 6 & 4 & 638 & $\mathrm{NC}$ & 1,045 & 258 & 82 & 83 & 6 & 14 & 10 & 1,498 \\
\hline AR & 283 & 70 & 22 & 22 & 2 & 4 & 3 & 405 & ND & 104 & 33 & 7 & 2 & 7 & 4 & 6 & 163 \\
\hline $\mathrm{AZ}$ & 322 & 76 & 40 & 30 & 8 & 13 & 5 & 495 & $\mathrm{NE}$ & 262 & 62 & 33 & 25 & 7 & 10 & 4 & 403 \\
\hline CA & 2,575 & 612 & 323 & 241 & 67 & 103 & 40 & 3,691 & $\mathrm{NH}$ & 213 & 109 & 5 & 5 & 4 & 3 & 11 & 350 \\
\hline $\mathrm{CO}$ & 485 & 115 & 61 & 45 & 13 & 19 & 8 & 745 & $\mathrm{NJ}$ & 982 & 501 & 21 & 22 & 19 & 15 & 50 & 1,610 \\
\hline $\mathrm{CT}$ & 642 & 328 & 14 & 14 & 12 & 10 & 33 & 1,053 & NM & 157 & 37 & 20 & 15 & 4 & 6 & 2 & 241 \\
\hline $\mathrm{DE}$ & 113 & 58 & 2 & 2 & 2 & 2 & 6 & 185 & NV & 154 & 37 & 19 & 14 & 4 & 6 & 2 & 237 \\
\hline $\mathrm{FL}$ & 2,342 & 574 & 183 & 184 & 13 & 31 & 23 & 3,330 & NY & 1,263 & 645 & 27 & 28 & 24 & 20 & 65 & 2,071 \\
\hline GA & 842 & 208 & 66 & 67 & 5 & 11 & 8 & 1,207 & $\mathrm{OH}$ & 1,311 & 414 & 92 & 26 & 89 & 50 & 81 & 2,062 \\
\hline IA & 409 & 129 & 29 & 8 & 28 & 16 & 25 & 644 & $\mathrm{OK}$ & 312 & 74 & 39 & 29 & 8 & 12 & 5 & 481 \\
\hline ID & 284 & 26 & 4 & 2 & 3 & 4 & 2 & 325 & OR & 718 & 66 & 10 & 4 & 7 & 11 & 5 & 822 \\
\hline IN & 688 & 217 & 48 & 14 & 47 & 26 & 43 & 1,083 & $\mathrm{RI}$ & 110 & 56 & 2 & 2 & 2 & 2 & 6 & 181 \\
\hline $\mathrm{KS}$ & 452 & 108 & 57 & 42 & 12 & 18 & 7 & 696 & SC & 516 & 127 & 41 & 41 & 3 & 7 & 5 & 740 \\
\hline KY & 354 & 87 & 28 & 28 & 2 & 5 & 3 & 507 & $\mathrm{SD}$ & 113 & 36 & 8 & 2 & 8 & 4 & 7 & 178 \\
\hline LA & 421 & 104 & 33 & 33 & 2 & 6 & 4 & 603 & $\mathrm{TN}$ & 497 & 123 & 39 & 39 & 3 & 7 & 5 & 712 \\
\hline MA & 836 & 427 & 18 & 18 & 16 & 13 & 43 & 1,370 & TX & 1,514 & 360 & 190 & 142 & 39 & 60 & 24 & 2,329 \\
\hline $\mathrm{MD}$ & 513 & 262 & 11 & 11 & 10 & 8 & 26 & 842 & UT & 159 & 38 & 20 & 15 & 4 & 6 & 2 & 244 \\
\hline $\mathrm{ME}$ & 214 & 109 & 5 & 5 & 4 & 3 & 11 & 351 & VA & 683 & 169 & 54 & 54 & 4 & 9 & 7 & 979 \\
\hline MI & 1,222 & 386 & 86 & 24 & 83 & 47 & 76 & 1,923 & VT & 125 & 64 & 3 & 3 & 2 & 2 & 6 & 205 \\
\hline $\mathrm{MN}$ & 639 & 202 & 45 & 1,370 & 43 & 24 & 40 & 2,363 & WA & 1,325 & 122 & 18 & 7 & 13 & 21 & 10 & 1,515 \\
\hline MO & 745 & 184 & 59 & 59 & 4 & 10 & 7 & 1,068 & WI & 617 & 195 & 43 & 12 & 42 & 23 & 38 & 970 \\
\hline MS & 236 & 58 & 19 & 19 & 1 & 3 & 2 & 339 & WV & 193 & 48 & 15 & 15 & 1 & 3 & 2 & 276 \\
\hline
\end{tabular}

Source: NEOS Corp. (1994) 
The 1994 study also documented UTR disposal methods throughout the United States. Although the study attempted to estimate landfilling costs, no price information for residue sold was obtained. On a national level, the amount of residue either given away or landfilled is reportedly in excess of $75 \%$ of total residue production. Further, only $10 \%$ of survey respondents indicated that they made money on their residue disposal methods.

Clearly, the value of residues is not high, and most organizations are either losing money or breaking even on residue disposal. Most people reported that they were happy "just to get rid of it" without incurring significant transportation costs or paying landfill tip fees. Sixty-two percent of the respondents indicated that they were satisfied with their residue disposal actions; $69 \%$ indicated that they would consider alternative disposal methods. Given the experience of the small number of organizations that actually make money with residues and growing markets for mulch, compost, lumber products, and energy conversion, more organizations will likely try to profit from their residues in the future.

As noted earlier, the predominant type of UTR is chips. Therefore, looking at chip disposal methods is illustrative. Figure 36 shows the disposal methods for UTR chips. Fifty-four percent of chips are given away. Landfilling represents the second-largest fraction (15\%), and "left on site" is third. In 1994, 12\% of the material was being sold, and 5\% was being processed at recycling centers. The "other" disposal methods include animal bedding, mixing with sewage, applying to low spots for land leveling, and "midnight dumping."

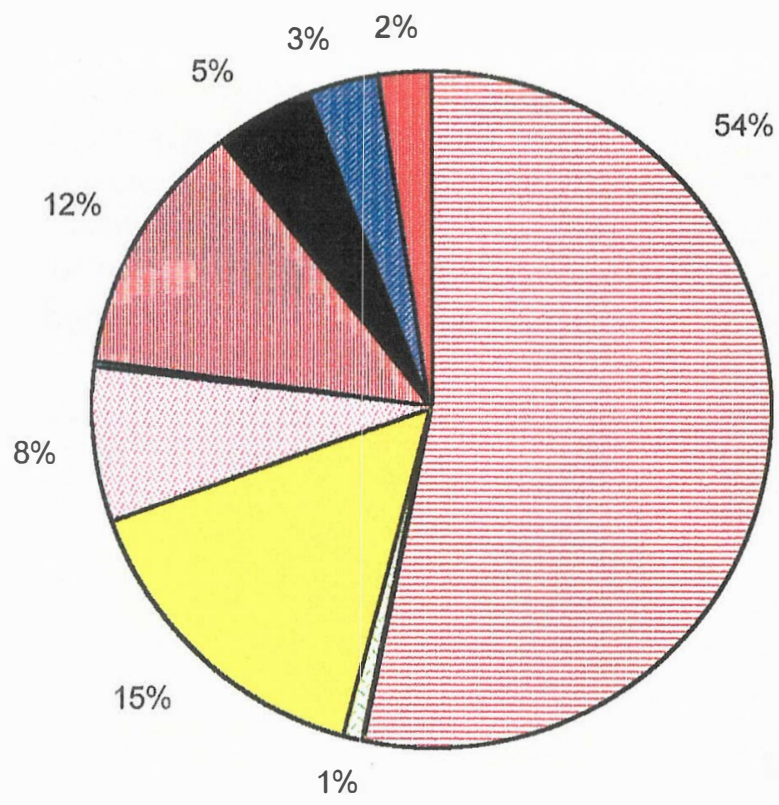

Given Away (54\%)

Burn for Energy (1\%)

Incinerate $(<1 \%)^{*}$

Landfill (15\%)

Leave on Site (8\%)

Open Burn $(<1 \%)^{*}$

Sold (12\%)

Recycling Center (5\%)

Used on Site (3\%)

Other $(2 \%)$

* Values less than $1 \%$ are not illustrated in pie chart.

Figure 36. Disposal methods for UTR chips

Source: NEOS Corp. (1994)

Figure 37 illustrates the end markets for UTR chips that are sold. The mulch market commands 53\%, followed by energy at $29 \%$ (boiler fuel at $21 \%$ plus firewood at $8 \%$ ), and compost (12\%). Wood products and "other" make up the balance of the chip material sold. UTR markets vary significantly in different regions, and product sales are highly dependent on local conditions and the presence or absence of various industries (e.g., compost manufacturers, mulch manufacturers, biomass energy facilities). No information was available on price received for UTR sold. 


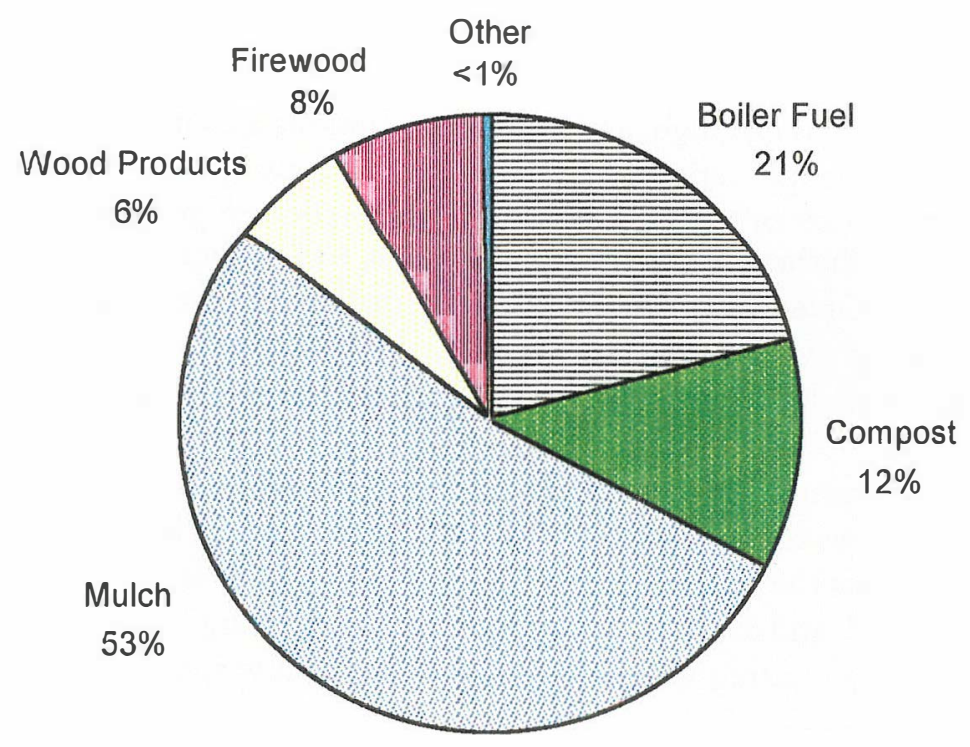

Figure 37. End use of UTR chips that are sold

Source: NEOS Corp. (1994)

Figure 38 shows the survey data for disposal practices by region. The regions listed below are the same as those used by the DOE Regional Biomass Energy Programs (RBEPs). The percentage of residue given away is high in every region, ranging from $40 \%$ in the Northeast, Southeast, and West to more than $70 \%$ in the Pacific Northwest. The Northeast leads the nation in residue sold, followed closely by the West. The Southeast is the only region where the amount of material landfilled (approximately 30\%) exceeds the percentage sold. The West leads in recycling rates, where almost $20 \%$ of the residue recycled.

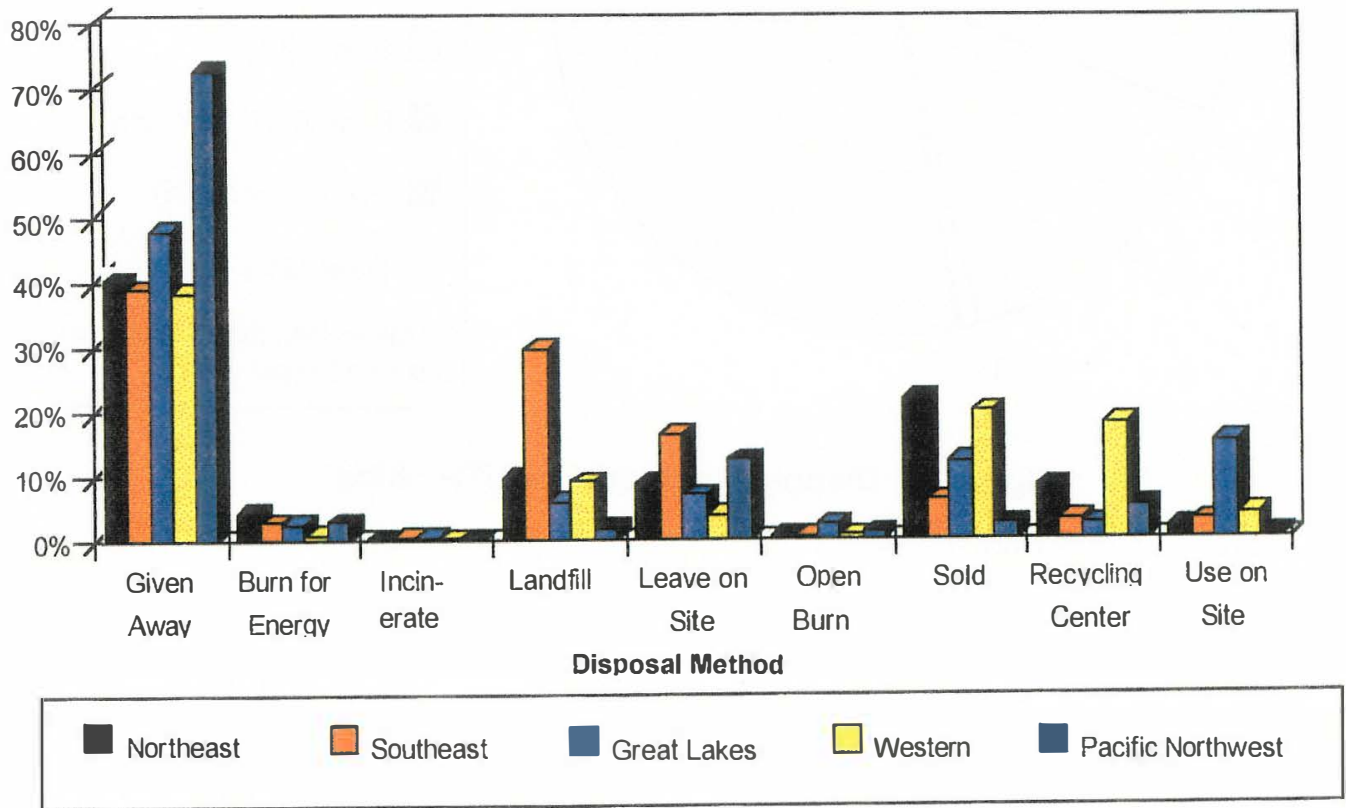

Figure 38. Residue disposal method by US DOE RBEP regions

Source: NEOS Corp. (1994) 
Total UTR production in the United States, shown in Figure 39, is not all available or unused. To determine the availability of UTR feedstock, we assumed that all the material not being sold or recycled would be available for conversion in an ethanol plant. Availability is tabulated and summarized regionally (Table 33), based on the 1994 results and disposal methods by region.

To obtain estimates of UTR availability, the amount of UTR produced in each state was multiplied by the appropriate regional percentage listed in Table 33. Table 34 shows the values for availability. An estimated $38,000,000$ bone dry tons/year of UTR are available nationally. The UTR availability map is shown in Figure 40. As expected, UTR production is greatest in the states that have large urban populations and significant tree cover. Leading states for UTR include California, Florida, Texas, Illinois, New York, Minnesota, Pennsylvania, and Ohio.

As mentioned earlier, no information on the price received when UTR is sold was obtained. Disposal costs were also difficult to obtain; however, two sources were located and are presented here.

Table 35 shows disposal costs for urban wood waste and UTR. The urban wood waste disposal costs were obtained from Chartwell Information Publishers, Inc. The Chartwell data are for "urban wood waste" sources (including UTR, pallets, construction, demolition) and are reported by landfills on a dry ton basis.

Chartwell cost data show significant variation, with a low of $\$ 4 /$ dry ton in Alabama to a high of $\$ 154 /$ dry ton in New Jersey. Generators in states with high wood waste disposal costs (Connecticut, Massachusetts, Maine, New York, Oregon, Rhode Island, Washington, and West Virginia) are likely searching for alternative disposal options.

Table 33. Estimated UTR availability by region

\begin{tabular}{|c|c|}
\hline RBIP Resion & 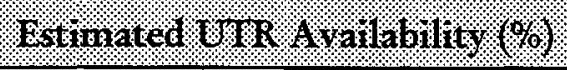 \\
\hline Northeast & $70 \%$ \\
\hline Southeast & $91 \%$ \\
\hline Great Lakes & $86 \%$ \\
\hline West & $63 \%$ \\
\hline Pacific Northwest & $93 \%$ \\
\hline
\end{tabular}

Source: NEOS Corp. (1994)

NEOS landfill cost data are based on the same UTR study used throughout this section. The NEOS data have been converted from \$/cubic yard to \$/dry ton using a conversion factor of 3.3 yards/wet ton and an assumed moisture content of $50 \%$. The NEOS data are based on regional disposal costs for only survey respondents that reported both a cost for landfilling and the quantity of material that was landfilled. Each state was then assigned a UTR landfill cost based on the RBEP region in which it is located.

Because the NEOS data are based on regional estimates, care must be taken in interpreting the results. For example, Idaho and Montana are not likely to have landfill costs in the $\$ 100$ range. These values are for the Northwest, and are heavily influenced by data from Oregon and Washington. However, the data do provide an order of magnitude estimate, and when used in conjunction with the Chartwell data, a relative cost of UTR disposal can be ascertained. 
Table 34. UTR production and availability (1,000 dry tons)

\begin{tabular}{|c|c|c|c|c|c|}
\hline State & Trotal & Avariable Yuratity & stare & Coutantity. & A \\
\hline $\mathrm{AL}$ & 638 & 582 & NC & 1,498 & 1,367 \\
\hline AR & 405 & 370 & ND & 163 & 102 \\
\hline $\mathrm{AZ}$ & 495 & 311 & $\mathrm{NE}$ & 403 & 253 \\
\hline CA & 3,961 & 2,487 & NH & 350 & 246 \\
\hline $\mathrm{CO}$ & 745 & 468 & $\mathrm{NJ}$ & 1,610 & 1,132 \\
\hline $\mathrm{CT}$ & 1,053 & 740 & NM & 241 & 151 \\
\hline $\mathrm{DE}$ & 185 & 130 & NV & 237 & 149 \\
\hline FL & 3,330 & 3,038 & NY & 2,071 & 1,456 \\
\hline GA & 1,207 & 1,101 & $\mathrm{OH}$ & 2,062 & 1,768 \\
\hline IA & 644 & 552 & OK & 481 & 302 \\
\hline ID & 325 & 302 & OR & 822 & 764 \\
\hline IL & 2,675 & 2,294 & PA & 2,478 & 1,743 \\
\hline IN & 1,083 & 929 & $\mathbf{R I}$ & 181 & 127 \\
\hline KS & 696 & 437 & SC & 740 & 675 \\
\hline $\mathrm{KY}$ & 507 & 463 & SD & 178 & 112 \\
\hline LA & 603 & 550 & TN & 712 & 650 \\
\hline MA & 1,370 & 963 & $\mathrm{TX}$ & 2,329 & 1,463 \\
\hline $\mathrm{MD}$ & 842 & 592 & UT & 244 & 153 \\
\hline $\mathrm{ME}$ & 351 & 247 & VA & 979 & 893 \\
\hline MI & 1,923 & 1,649 & VT & 205 & 144 \\
\hline $\mathrm{MN}$ & 2,363 & 2,026 & WA & 1,515 & 1,408 \\
\hline MO & 1,068 & 974 & WI & 970 & 832 \\
\hline MS & 339 & 309 & WV & 276 & 252 \\
\hline MT & 225 & 209 & WY & 137 & 86 \\
\hline & & & Total & 47,915 & 37,953 \\
\hline
\end{tabular}

Source: NEOS Corp. (1994) 
Table 35. Wood waste disposal costs

\begin{tabular}{|c|c|c|c|c|c|c|c|}
\hline State & 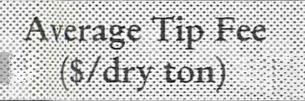 & 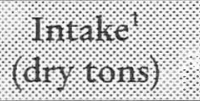 & 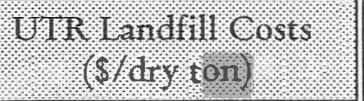 & State & ( & (11) & ( \\
\hline $\mathrm{AL}$ & $\$ 2.00$ & 1,200 & $\$ 50.49$ & NC & $\$ 26.15$ & 5,984 & $\$ 50.49$ \\
\hline AR & $\$ 25.00$ & 45 & no data & ND & $\$ 23.88$ & 65 & $\$ 66.92$ \\
\hline $\mathrm{AZ}$ & $\$ 20.66$ & 5,974 & $\$ 66.92$ & $\mathrm{NE}$ & $\$ 10.46$ & 150 & $\$ 66.92$ \\
\hline $\mathrm{CA}$ & $\$ 25.29$ & 50,340 & $\$ 66.92$ & $\mathrm{NH}$ & $\$ 18.48$ & 433 & $\$ 54.65$ \\
\hline $\mathrm{CO}$ & $\$ 13.03$ & 2,604 & $\$ 66.92$ & NJ & $\$ 77.48$ & 4,796 & $\$ 54.65$ \\
\hline $\mathrm{CT}$ & $\$ 43.29$ & 282 & $\$ 54.65$ & NM & $\$ 14.50$ & 80 & $\$ 66.92$ \\
\hline $\mathrm{DE}$ & $\$ 58.50$ & 1,450 & no data & NV & $\$ 1.50$ & 2,625 & $\$ 66.92$ \\
\hline FL & $\$ 24.45$ & 7,738 & $\$ 50.49$ & NY & $\$ 51.33$ & 3,193 & $\$ 54.65$ \\
\hline GA & $\$ 17.00$ & 350 & $\$ 50.49$ & $\mathrm{OH}$ & $\$ 25.12$ & 15,290 & $\$ 73.13$ \\
\hline IA & $\$ 19.15$ & 1,160 & $\$ 73.13$ & OK & $\$ 18.50$ & 500 & $\$ 66.92$ \\
\hline ID & $\$ 13.28$ & 671 & $\$ 105.47$ & OR & $\$ 50.16$ & 2,482 & $\$ 105.47$ \\
\hline IL & $\$ 15.02$ & 883 & $\$ 73.13$ & $\mathrm{PA}$ & $\$ 32.00$ & 1,200 & $\$ 54.65$ \\
\hline IN & $\$ 21.50$ & 275 & $\$ 73.13$ & $\mathrm{RI}$ & $\$ 52.00$ & 3,250 & $\$ 54.65$ \\
\hline $\mathrm{KS}$ & $\$ 18.82$ & 255 & $\$ 66.92$ & SC & $\$ 23.33$ & 900 & $\$ 50.49$ \\
\hline KY & $\$ 36.51$ & 925 & no data & SD & $\$ 16.00$ & 125 & $\$ 10.14$ \\
\hline LA & $\$ 7.50$ & 50 & $\$ 66.92$ & $\mathrm{TN}$ & $\$ 20.72$ & 3,615 & $\$ 50.49$ \\
\hline MA & $\$ 74.85$ & 1,346 & $\$ 54.65$ & $\mathrm{TX}$ & $\$ 9.10$ & 4,853 & $\$ 66.92$ \\
\hline $\mathrm{MD}$ & $\$ 31.91$ & 2,355 & $\$ 54.65$ & UT & $\$ 21.15$ & 3,384 & $\$ 66.92$ \\
\hline $\mathrm{ME}$ & $\$ 40.42$ & 180 & $\$ 54.65$ & VA & $\$ 30.28$ & 13,717 & $\$ 50.49$ \\
\hline MI & $\$ 8.81$ & 4,930 & $\$ 73.13$ & VT & $\$ 0.00$ & 114 & $\$ 54.65$ \\
\hline MN & $\$ 9.60$ & 35 & $\$ 73.13$ & WA & $\$ 74.50$ & 600 & $\$ 105.47$ \\
\hline MO & $\$ 23.40$ & 2,470 & $\$ 105.47$ & WI & $\$ 37.03$ & 3,585 & $\$ 73.13$ \\
\hline MT & $\$ 0.00$ & 45 & $\$ 105.47$ & WV & $\$ 43.75$ & 500 & $\$ 54.65$ \\
\hline \multicolumn{5}{|c|}{ Total/Average } & $\$ 27.44$ & 154,629 & $\$ 65.28$ \\
\hline
\end{tabular}

Sources: ${ }^{1}$ Chartwell Information Publishers (1996); ${ }^{2}$ NEOS Corporation (1994) 


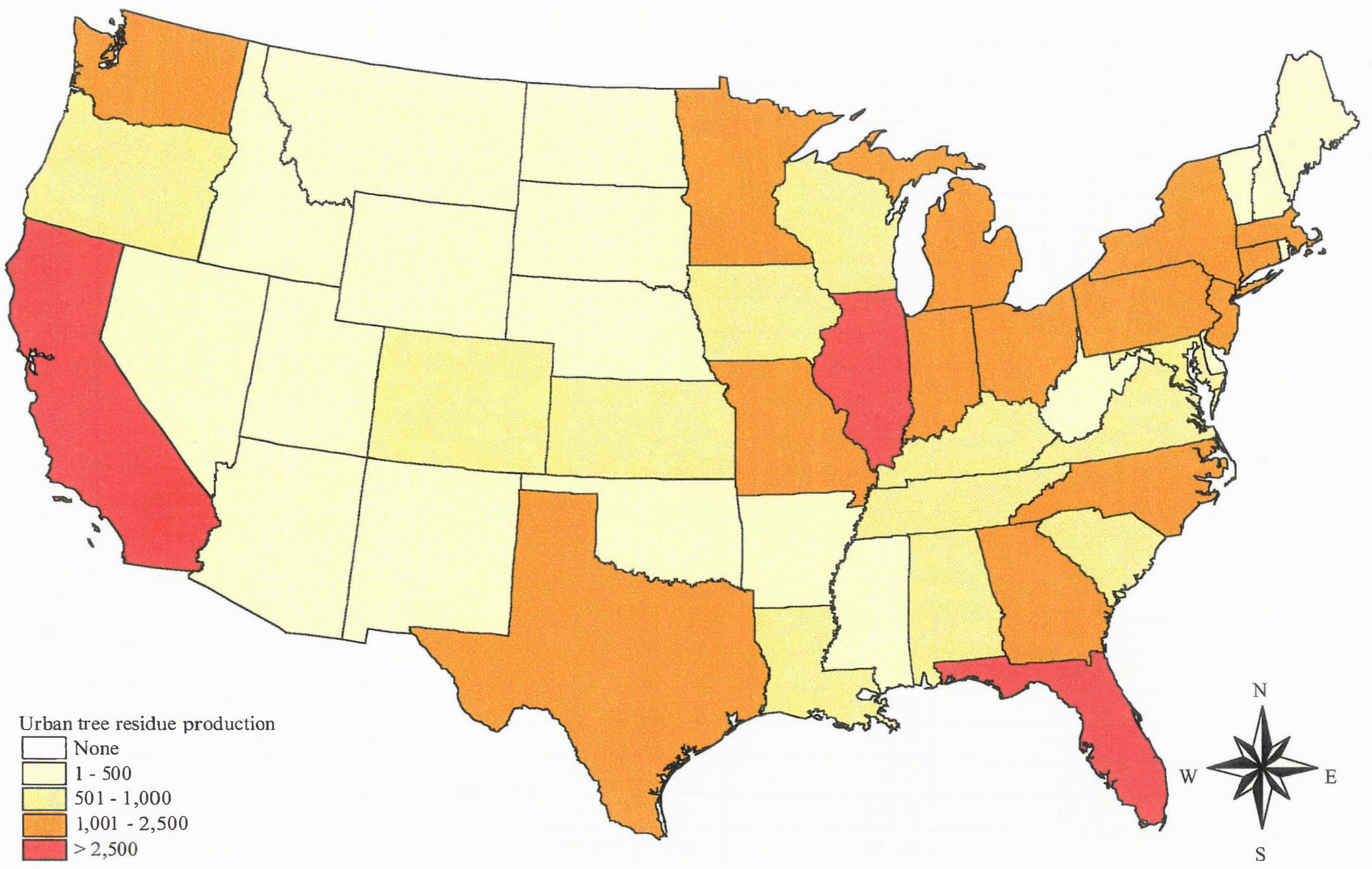

Figure 39. Total urban tree residue production (thousand dry tons/year) 


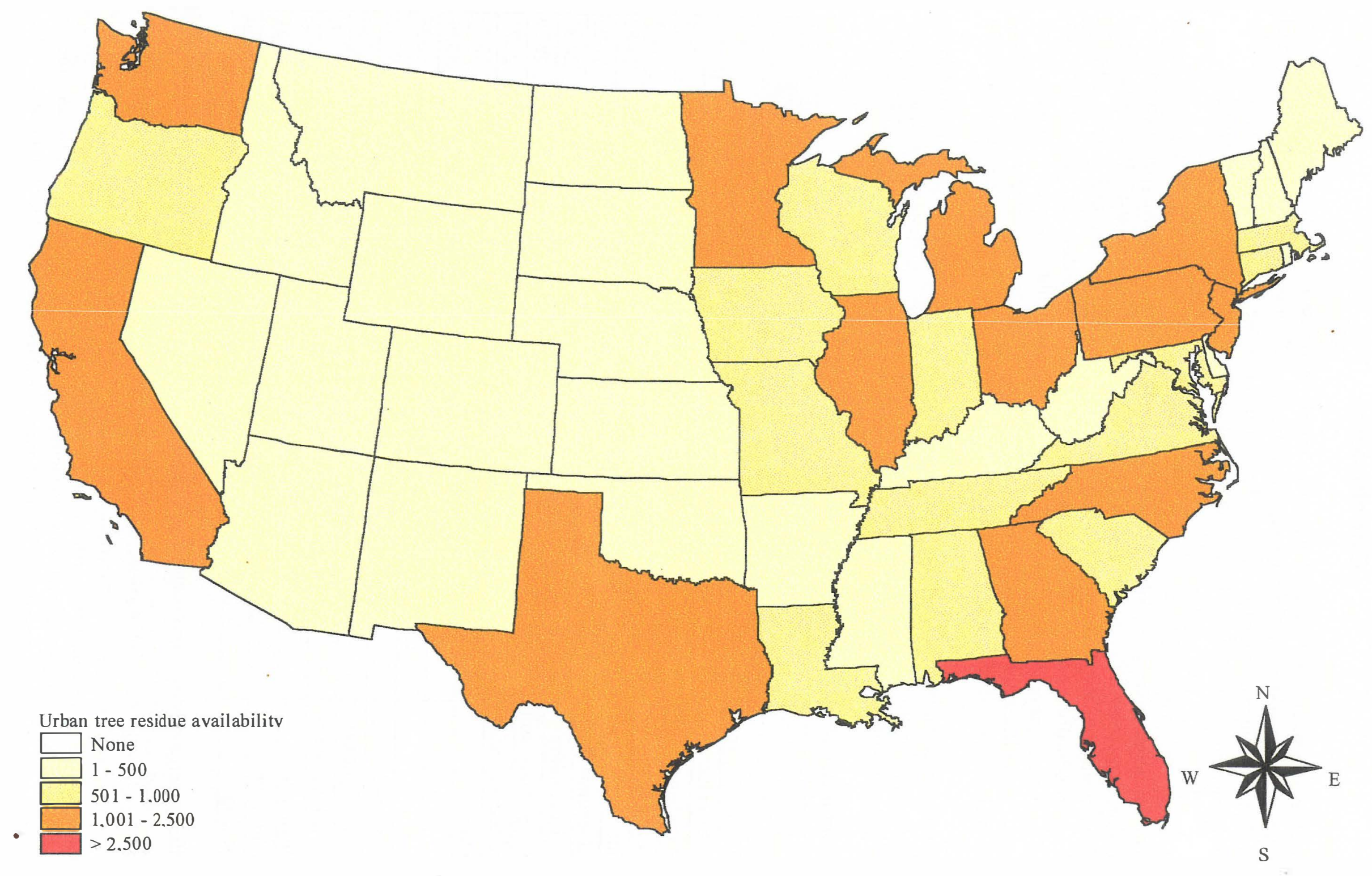

Figure 40. Available urban tree residue (thousand dry tons/year) 


\section{Conclusions}

This resource assessment provided feedstock data at the state level for use as a macro-level screening tool. Data included were obtained primarily from existing sources. Local, site-specific market studies need to be conducted to make siting decisions for individual production facilities. Nonetheless, the overall results allow candidate feedstocks to be ranked for ethanol conversion and technology transfer efforts.

Significant negative prices for UTR and recycled primary paper pulp sludge make these feedstocks good candidates for further research (Table 36). The conditions that may allow commercial applications of ethanol conversion technology differ for the two feedstocks, however. In the case of UTR, a feedstock of heterogeneous quality available from many sources, the negative price of the feedstock may be offset by higher ethanol production costs and feedstock handling issues. UTR generators that may produce feedstocks that are more homogeneous include land clearance contractors, utilities, and parks and recreation departments. Private landscapers, municipalities, and arborists often generate large quantities of woody debris with high foliage and grit content, as well as feedstocks with a variety of extraneous materials.

Recycled primary paper pulp sludge is likely to be easier to process and more homogeneous, with lower transportation costs for on-site production facilities. Kerstetter et al. (1997) indicate that ethanol conversion efficiency and economies of scale are crucial for the viability of paper sludge-to-ethanol facilities.

Table 36. Summary of 1996 available feedstock quantity and price (ranked by price)

\begin{tabular}{|c|c|c|c|}
\hline & \multicolumn{2}{|c|}{ (1) } & \multirow{2}{*}{ P. Price lo lon } \\
\hline & 1,000 div : tons: & $06.01 .60 t .1 \%$ & \\
\hline Recycled primary paper & $3,358.1$ & 1.0 & $(32.21)$ \\
\hline Urban tree residue & $37,953.0$ & 11.3 & $(27.44)$ \\
\hline Mixed office paper & $4,857.0$ & 1.4 & 2.08 \\
\hline Sugarcane bagasse & 708.6 & 0.2 & 5.84 \\
\hline Newsprint & $11,232.0$ & 3.3 & 14.88 \\
\hline Softwood secondary & 607.6 & 0.2 & 20.03 \\
\hline Hardwood secondary & 440.9 & 0.1 & 20.10 \\
\hline Hardwood primary mill & 978.5 & 0.3 & 22.32 \\
\hline Softwood primary mill & $1,255.4$ & 0.4 & 22.75 \\
\hline Corn stover & $233,614.9$ & 69.6 & 25.26 \\
\hline Rice & $2,666.1$ & 0.8 & 43.06 \\
\hline Hay-alfalfa & $28,567.8$ & 8.5 & 90.55 \\
\hline Corn gluten feed & $5,664.5$ & 1.7 & 95.23 \\
\hline Spent brewers' grains & $1,064.4$ & 0.3 & 130.84 \\
\hline Distillers' dried grains & $1,797.9$ & 0.5 & 131.93 \\
\hline Corn gluten meal & $1,119.8$ & 0.3 & 206.98 \\
\hline Small grain straw & 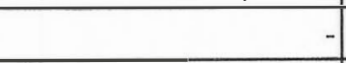 & 0.0 & $\mathrm{~N} / \mathrm{A}$ \\
\hline Total/Average & $333,885.5$ & 100.0 & 44.49 \\
\hline
\end{tabular}

Mixed office paper, sugarcane bagasse, and corn stover (listed in order of increasing cost) will be available at positive prices, but are low enough in value to warrant attention as viable candidates for ethanol production technologies (Table 9). Regional mixed office paper price variability substantially impacts its viability as a feedstock in some locations. Although national average prices are positive, spot prices in the Northeast are negative, meaning the Northeast may present opportunities for office paper to be used as an ethanol feedstock. Sugarcane bagasse is also low-cost, although most (80\%) is currently used (bagasse data in Table 9 indicate unused quantities). The efficiency of bagasse conversion facilities may also affect 
bagasse viability. More bagasse may be available given the marginal value of sugarcane bagasse used in some low-efficiency electricity and heat generation applications. Sugarcane bagasse and rice straw are currently commercial feedstocks for ethanol production. Waste paper has been investigated as an ethanol feedstock since the 1990s in the Northeast. Corn stover is the single largest potential feedstock (Table 9). The actual value of the feedstock is subject to some question due to the variation in estimates of the value of corn stover for forage and soil conservation. Regional and local variation in soil conditions and soil nutrient availability affect the price and availability of corn stover to a greater degree than indicated in the current resource assessment.

Newsprint and mill residues are intermediate in value and are mostly collected and used (Table 9). However, the size of these resources still leaves a large amount potentially available for ethanol production. Newsprint follows similar geographic trends as mixed office paper, with the northeastern United States being an important area for further examination. Primary mill residues are mostly used by the producers or sold to pulp and paper producers. The high value of coarse mill residues makes it unlikely that they will play a part in future ethanol production efforts. Fine primary residues are less costly. Secondary mill residues are often unused and of lower value than primary residues.

Rice straw is marginally attractive as an ethanol feedstock due to its high collection costs (Table 9). Other feedstocks such as brewers and distillers dried grains, corn fiber, and hay-alfalfa straw have high value as ruminant and poultry feeds, and are not likely to be economically viable stand-alone ethanol feedstocks given current transportation fuel prices (Table 9).

A number of data availability issues affected the accuracy and usability of the data used to derive residue estimates. State-level data on competing uses for agricultural residues used in forage or other competing uses may be more meaningful for potential ethanol producers than estimates of availability based on soil conservation requirements. Information on the willingness of farmers to shift from forage practices to residue collection and sale could provide a basis for estimation of agricultural residues consumed in "noncaptive" uses. Primary wood residue data should be updated with more recent mill residue production data when available in 1998 from the USDA Forest Service. Secondary mill residue data should be expanded to include regional variation in residue production coefficients that are currently being developed in several areas of the United States. Also, estimates should be performed for individual SIC classes when SIC-specific residue coefficients are compiled by Pennsylvania State University and TVA. If paper recovery data were available on a state (or at least a regional) level, state newsprint and office paper estimates would be more reliable. Spent brewers' grain estimates are probably the most reliable given the availability of estimates for all producers in the United States. Feedstock processing and ethanol conversion research can improve the viability of converting mixed foliage and wood from UTR into ethanol. 


\section{Glossary \\ (Definitions based on DOE/SERI [September 1986])}

bagasse residue remaining after extraction of a sugar-containing juice from plants such as sugarcane.

beer a fermented broth that consists of water, ethanol, and small amounts of ether and assorted alcohols.

biomass the total weight of living matter in a given volume. Biomass is further subdivided when considered as an energy resource into : (1) primary biomass-rapidly growing plant material that may used directly or after a conversion process for energy production; and (2) secondary biomass-residues remaining after the production of fiber, food, or other products of agriculture, or biomass by-products from animal husbandry or food prepara- tion that are modified physically rather than chemically. Examples include waste materials from agricultural and forestry industries (manure, sewage, etc.), from which energy may be produced. The distinction between primary and secondary biomass is based on economic factors; these terms are defined differently in ecological science.

Also, material, excluding fossil fuels, which is or was a living organism that can be used as a fuel directly or after a conversion process (wood, peanut hulls, agriculture waste, corn and other grains, sugar, and bagasse are all examples of biomass). Matter formed from living cells. Any organic matter, including forest residues, agricultural crops and wastes, wood and wood waste, animal wastes, livestock operational residues, aquatic plants, and municipal wastes, that is available and renewable.

Also, the living materials in the biosphere and their refuse and waste products. Defined in the Energy Security Act (PL 96-294) as any organic matter that is available on a renewable basis, including agricultural crops and agricultural wastes and residues, wood and wood wastes and residues, animal wastes, municipal wastes, and aquatic plants.

black liquor the dark, alkaline waste liquor from the manufacture of pulp by the kraft (sulfate) process or the soda process. Usually concentrated and burned in a furnace to recover heal and chemicals.

bone dry ton 2,000 pounds of moisture-free wood, unless otherwise stated.

British thermal unit (Btu) the amount of heat required to raise the temperature of 1 pound of water $1^{\circ} \mathrm{F}$ under one stated condition of pressure (one atmosphere) and temperature (from $60^{\circ}$ to $61^{\circ} \mathrm{F}$ ).

bulk density weight per unit volume of materials as packed in a container.

cellulose the carbohydrate that is the principal constituent of wood and forms the structural framework of the wood cells.

cofiring the use of a mixture of two fuels, e.g., wood and coal, within the same combustion chambers.

coarse residue plant residue, such as slabs, edgings, and veneer cores, suitable for chipping.

corn stover the refuse of a corn crop after the grain is harvested.

distillers dried grains (DDG) the dried grain by-product of the grain fermentation process, which may be used as a high-protein animal feed.

ethanol (ethyl alcohol, grain alcohol) $\mathrm{CH}_{3} \mathrm{CH}_{2} \mathrm{OH}$; can be produced chemically from ethylene or biologically from the fermentation of various sugars from carbohydrates found in agricultural crops and cellulose residues from crops or wood.

feedstock any material used as a fuel directly or converted to another form of fuel or energy product. 
fermentation decomposition of organic compounds by microorganisms, to fuels and chemicals such as alcohols, acids, and energy-rich gases.

fines particles smaller than the size specified. Usually expressed as percent by weight.

glucose: $\left(\mathrm{C}_{6} \mathrm{H}_{12} \mathrm{O}_{6}\right)$; a simple sugar containing six carbon atoms. A sweet, colorless sugar that is the most common sugar in nature and the primary component of starch and cellulose. The sugar most commonly fermented by yeast to produce ethyl alcohol.

hemicellulose non-cellulosic polysaccharides of the cell wall that are easily decomposed by dilute acid, yielding several different simple sugars.

hydrolysis the conversion, by reaction with water, of a complex substance into two or more smaller units, such as the conversion of cellulose into smaller sugar units.

lignin the non-carbohydrate, structural constituent of wood and some other plant tissues that encrusts the cell walls and cements the cells together. Lignin types include:

*alkali lignin: lignin obtained by acidification of an alkaline extract of wood.

"klason lignin: lignin obtained from wood after the non-lignin components of the wood have been removed with a prescribed sulfuric acid treatment.

"native lignin: the lignin as it exists in the lignocellulosic complex before separation.

"willstatter lignin: lignin obtained from the lignocellulosic complex after it has been extracted with fuming hydrochloric acid.

lignocellulose refers to plant materials made up primarily of lignin, cellulose, and hemicelluloses.

manufacturing (or mill) residue unused materials other than the primary products (such as lumber or sugarcane syrup), obtained from raw materials.

moisture content the amount of water contained in the biomass, expressed as either a percentage of the mass of the oven dry biomass or of the wet biomass.

moisture content, dry basis $=$ (weight wet sample-weight dry sample) $\times 100$

moisture content, wet basis $=($ weight wet sample-weight dry sample) $\times 100$

municipal solid waste (MSW) the refuse materials collected from urban areas in the form of organic matter, glass, plastics, wastepaper, etc., not including human wastes.

sludge a nonpumpable mixture of solids and liquids. Often refers to the residue of sewage treatment.

spent grains the nonfermentable solids remaining after fermentation of a grain mash.

windrow piles of bark, sawdust, logging residues, or other materials produced in land clearing for storage. The piles are usually triangular in cross-section and of variable length and height. 


\section{References}

Advanstar Communications (July 1996 through June 1997). "Transacted Paper Stock Prices." Official Board Markets 72(28)-73(24).

Ahmed, I.; Morris, D. (1992). How Much Energy Does It Take to Make a Gallon of Ethanol. Washington, DC: Institute for Local Self Reliance.

Alerich, C.; Drake, D. (1995). Forest Statistics for New York: 1980 and 1993. Radnor, PA: USDA Forest Service Northeastern Forest Experiment Station.

American Forest and Paper Association. (1996). Recovered Paper Statistical Highlights. Washington, DC.

Ayers, G.E.; Williams, D.L. (1983). Estimating Field Capacity of Farm Machines. Machinery Management Series PM-696 (reprinted). Ames, IA: Iowa State University Cooperative Extension Service.

Chandler, P.T. (1997). Personal communication. Dresden, TN: Chandler \& Associates, Inc., August.

Chandler, P.T. (1991). "Feeding Brewers Grain." In Proceedings: Alternative Feeds for Dairy and Beef Cattle. September 22-24. St. Louis, MO: USDA Extension Service and Allied Industries, in cooperation with University of Missouri University Conference Extension Office.

Corn Refiners Association, Inc. (1997). 1997 Corn Annual. Washington, DC.

Decision Analysis Corporation of Virginia. (1995). Data Documentation for the Biomass Cost-Supply Schedule, Report: Subtask 2b. Department of Energy, Contract No. DE-AC01-92EI21946, Task 95115. Available on line at rredc.nrel.gov/biomass.

Domalski, E.S.; Lobe, T.L. Jr. (1986). Thermodynamic Data for Biomass Conversion and Waste Incineration. Gaithersburg, MD: Chemical Thermodynamics Division, Center for Chemical Physics, and the Office of Standard Reference Data, National Bureau of Standards.

Duffy, M.; Vontalge, A. (1996). Estimated Costs of Crop Production in Iowa, 1997. Ames, IA: Iowa State University Extension Service; FM-1712/Revised.

Dyer, H. (1997). 1997 Lockwood Post's Directory of the Pulp, Paper, and Allied Trades. New York, NY: Miller Freeman Publications.

Fisher J. (1992). Urban Tree Residue: An Assessment of Wood Residue from Landscapers and Landfills. Minnetonka, MN: Minnesota Department of Natural Resources Division of Forestry.

Fox, P. (1987). Energy from Crops and Agricultural Residues in Montana. Helena, MT: Montana Department of Natural Resources.

Franklin Associates, Ltd. (1997). Characterization of Municipal Solid Waste in the United States. EPA530R-97-015. Washington, DC: U.S. Environmental Protection Agency. Work performed by Franklin Associates, Ltd., Prairie Village, KS.

Frolich, M. (1996). "Tri-County Pre-Commercial Analysis of Converting Wastes to Marketable Products." Bioenergy '96: Proceedings of the Seventh Annual Bioenergy Conference; Partnerships to Develop and Apply Biomass Energy Technologies. September 15-20. Nashville, TN: U.S. Department of Energy Southeastern Regional Biomass Energy Program, Muscle Shoals, AL, pp. 429-436. 
Gatto, S. (1997). Personal communication. Jennings, LA: BCI International Corp., November.

Goldstein, N.; Glenn, J. (1997). "The State of Garbage in America." BioCycle Journal of Composting and Recycling 38(5):60-75.

Ince, P. (1994). Recycling and Long-Range Timber Outlook. Fort Collins, CO: USDA Forest Service Rocky Mountain Forest and Range Experiment Station.

Institute for Brewing Studies. (1996) Brewers Resource Directory. Boulder, CO: Institute of Brewing Studies.

International Rice Research Institute (IRRI). (1997). RiceWeb. Available on line at www.riceweb.org.

Jamski, J. (1997). Suitland, MD: U.S. Department of Commerce, Bureau of the Census. Unpublished report.

Johnson, T. (1997). Asheville, NC: USDA Forest Service Southern Forest Experiment Station. Personal Communication, October.

Jose, H.; Brown, L. (1996). Cost of Harvesting and Hauling Corn Stalks in Large Round Bales. Field Crops C-2, Corn. October. Lincoln, NE: University of Nebraska Cooperative Extension Service.

Kerstetter, J.; Lynd, L.; Lyford, K.; South, C. (1997). Assessment of Potential for Conversion of Pulp and Paper Sludge to Ethanol Fuel in the Pacific Northwest. Golden, CO: U.S. Department of Energy National Renewable Energy Laboratory.

Lazarus, W. (1997). Farm Machinery Economic Costs for 1997: Minnesota Estimates with Adjustments for Use in Canada. Staff Paper Series P97-7. Department of Applied Economics College of Agricultural, Food, and Environmental Sciences. University of Minnesota.

Legendere, B. (1997). Louisiana State University Cooperative Extension Service. Personal communication, November.

Mahanna, B; Kezar, W; Igarashi, H. (1996). Managing and Feeding the TMR Plant. Pioneer Hi Bred International, Inc. Available on line at www.pioneer.com/consult/research/wpcs1.htm.

Miyata, R.; Miyata, E. (1981). Harvesting Wood for Energy. Research Paper NC-200. St. Paul, MN: USDA Forest Service North Central Forest Experiment Station.

Morgan, T. (1997). "Hay Gains Respect through Imports.” Farm Journal. Philadelphia, PA: Farm Journal, Inc. Available on line at www.farmjournal.com/FJ/farmjournal/start.cfm.

National Council of the Paper Industry for Air and Stream Improvement, Inc (NCASI). (1992) Solid Waste Management and Disposal Practices in the U.S. Paper Industry. Technical Bulletin No. 641. New York, NY: NCASI.

NEOS Corporation. (1994). Urban Tree Residues: Results of the First National Inventory. Final Report. International Society of Arboriculture Research Trust, Allegheny Power Service Corporation and National Arborist Foundation.

Onondaga County Resource Recovery Agency (OCRRA). (1993). 1993 Waste Quantification and Characterization: Executive Summary. Syracuse, NY: Work performed by Onondaga County Resource Recovery Agency. 
Palko, M. (1997). Harrisburg, PA: Division of Forestry, Pennsylvania Department of Natural Resources Division of Forestry. Personal communication, October.

Perry, R. (1984). Cost Estimation. Lincoln, NE: Cooperative Extension, University of Nebraska-Lincoln, Institute of Agriculture and Natural Resources. Available on line at: www.ianr.unl.edu/IANR/PUBS/ extnpubs/farmgmt/g208.htm\#ownership.

Prosek, C; Edmonds, J; Peterson, P; and Vieth, P. (1994). Minnesota Wood Waste Studies: One Man's Waste Is Another Man's Gold. St. Paul, MN: Minnesota Department of Natural Resources, Division of Forestry.

Rasby, R.; Selly, R. (1992). Grazing Crop Residue. Lincoln, NE; University of Nebraska Cooperative Extension Service. G92-1116-A.

Randazzo, M. (1997). "Ranking of Electricity Prices" and "Price Watch." Energy User News. Radnor, PA: Chilton Business News Magazine. pp. 76-77.

Renewable Fuels Association. (1997). "Ethanol Production on the Rise." Ethanol Report vol. 54. Available on line at: www.ethanolrfa.org/er080797.html.

Renewable Fuels Association. (1997). About the Producers. Available on line at: www.ethanolrfa.org/ prodcap.htl.

Schaffer, S. (1997). Washington, DC: Information Resources, Inc. Personal communication, October.

Schwartz, D. (1997). Washington, DC: Corn Refiners Association. Personal communication, October.

Skog, K.; Rosen, H. (1997). "US Wood Biomass for Energy and Chemicals: Possible Changes in Supply, End Uses and Environmental Impacts." Forest Products Journal 47(2)63-69.

Smith, B.; Faulkner, J.; Powell, D. (1994). Forest Statistics of the United States, 1992. General Technical Report NC-168. St. Paul, MN: USDA Forest Service North Central Forest Experiment Station.

Smith, M. (1995). "Processing and Utilizing Urban Wood Waste and Pallets for Fuel." In Proceedings of the Second Biomass Conference of the Americas: Energy, Environment, Agriculture, and Industry. August 21-24. Portland, OR, pp. 110-119.

Sneller, T. (1997). Lincoln, NE: Nebraska Ethanol Board. Personal communication, October.

Swanson, L. (1997). Minnetonka, MN: Miller Publishing. Personal communication, October.

Swanson, L. (April 1995-March 1996). Feedstuffs Magazine. Minnetonka, MN: Miller Publishing.

Thompson, J. (1997). Alexandria, VA: Chartwell Information Publishers. Personal communication, October.

Turhollow, A.; Downing, M.; Butler, J. (1996). "The Cost of Silage Harvest and Transport Systems for Herbaceous Crops." In Bioenergy '96: The Seventh National Bioenergy Conference: Partnership to Develop and Apply Biomass Technologies. September 15-20. Nashville, TN.

Tyson, K.S. (1991). Resource Assessment of Waste Feedstocks for Energy Use in the Western Regional Biomass Energy Area. Golden, CO: U.S. Department of Energy Western Regional Biomass Energy Program, p. 12. 
U.S. Department of Agriculture National Agricultural Statistics Service. (1997). Agricultural Statistics 1997. Washington, DC: Government Printing Office.

U.S. Department of Agriculture National Agricultural Statistics Service. (1996). NASS Surveys: the Foundation of Estimates. Washington, DC: Available on line at www.usda.gov/nass/nassinfo/estimate. htm\#objyield.

U.S. Department of Agriculture Economic Research Service. (1997). Feed Outlook: August 17, 1998. FDS0698. Available on line at jan.mannlib.cornell.edu/reports/erssor/field/fds-bb/1998/FDS0698.TXT.

U.S. Department of Commerce, Economic and Statistical Administration, Bureau of the Census. (1997). Industry Series-Grain Mill Products-Industries 2041, 2043, 2044, 2045, 2046, 2047, 2048, 1996. Washington, DC: U.S. Government Printing Office. Available on line at www.census.gov as text file entitled ma24t(96).

U.S. Department of Energy National Renewable Energy Laboratory. (1993). NREL Getting Extra "Corn Squeezins": Cooperative Agreement Uses Cellulosic Fiber to Get More Ethanol from Corn. Technology Brief NREL/MK-336-5639 (revised). Golden, CO: NREL.

U.S. Department of Energy Office of Transportation Technologies. (1997). Office of Transportation Technology Times 6(4)1,4.

U.S. Department of Energy Solar Energy Research Institute. (1986). Biofuels Glossary. Document SERI/SP271-2828. Golden, CO: U.S. Department of Energy Solar Energy Research Institute.

U.S. Department of Energy Southern Regional Biomass Energy Program. (1990). Regional Assessment of Non-forestry Related Biomass Resources: Summary Volume. Muscle Shoals, AL. Vienna, VA: JAYCOR. Available on line from rredc.nrel.gov/biomass/doe/rbep/summ_nfor/tl.html.

U.S. Department of Energy Western Regional Biomass Energy Program. (1991). Resource Assessment of Waste Feedstocks for Energy Use in the Western Regional Biomass Energy Area, Report. A Subcontract Report. Golden, CO: Energy and Environmental Analysis Division, Solar Energy Research Institute.

U.S. Department of Energy Western Regional Biomass Energy Program and the Western Area Power Administration. (1994). Draft Report on Agricultural Residue Harvest and Collection. Fargo, ND.

U.S. Executive Office of the President. Office of Management and Budget. (1987). Standard Industrial Classification Manual. Springfield, VA: National Technical Information Service.

Van Dyke, J. (1997). Washington, DC: USDA Agricultural Marketing Service, Livestock and Feed Division. Personal communication, October.

Walsh, M.; Becker D. (1996). Biocost Documentation. Oak Ridge, TN: Oak Ridge National Laboratory.

Worley, J.; Cundiff J. (1992). “Liquid Fuels from Renewable Resources.” In Proceedings of an Alternative Energy Conference. December, Nashville TN. Athens, GA: Agricultural Engineering Department, University of Georgia. 
DOE mailed letters to those fuel providers who have yet to report their model year 1997 acquisitions to the Alternative Fuel Transportation Program. The list of companies was developed with assistance from the major fuel provider associations and was narrowed to eliminate those that were not in an EPAct MSA. The list included executives of gas utilities, gas processors, gas pipelines, executives of electric utilities, propane companies, and a couple of ethanol companies.

One of three general responses are being sought:

1. Submission of reports for 1997 and possibly 1998.

2. A letter describing why the program does not apply, including rationale for that decision.

3. An explanation describing why a 1997 report was not submitted. Possible rationale includes the reporting of AFV acquisitions by a parent company, or the possibility that no light-duty AFVs were acquired by the organization in 1997.

These letters represent the first visible step in DOE's enforcement of the alternative fueled vehicle acquisition requirements. If no response is received within 60 days, a follow-up letter will be sent requesting a response within 30 days. If no response is received to the second letter, DOE will send a letter proposing fines and the specific violations associated with these fines. Companies will have 90 days to comply or reach a negotiated settlement with DOE.

Companies that failed to acquire the proper number of AFVs and wish to comply will be offered two initial options by DOE. First, we will suggest that the company add the number of AFVs they were acquire in 1997 (and possibly 1998) to the number of AFV acquisitions they will be required to obtain in 1999. Second, we will suggest that companies purchase enough AFV credits to bring them into compliance.

Please share this information with anyone you think may need it. If you have questions, please contact Ken Katz, Program Manager, at 202-586-6116. 
Appendix A: Crop Residue Budget Input Data 


\section{Cost Calculation Methods}

Calculated values in crop budgets included machine speed and efficiency, effective field capacity (EFC), opportunity costs of capital, and managerial costs, and productive equipment hours per machine per year. Machine speed and efficiency were calculated using a linear relationship with yield shown in Equation 1 (Walsh; Becker 1996).

Equation 1. $F(y)=a-b \times Y$

Where:

$$
\begin{aligned}
F(y) & =\text { Farm implement speed (miles / hour) or efficiency (acres / hour) } \\
a & =\text { Intercept } \\
b & =\text { Slope coefficient } \\
Y & =\text { Yield (dry tons / acre) }
\end{aligned}
$$

Calculated coefficients derived from Equation 1 are shown in Table A-1.

Table A-1. Agricultural machinery speed and efficiency equation coefficients

\begin{tabular}{|l|r|r|}
\hline \multicolumn{1}{|c|}{ Equipment } & Intercept & Slope Coefficient \\
\hline Swather & & \\
\hline Speed & 6.17 & -0.33 \\
\hline Efficiency & 87.67 & -1.33 \\
\hline Baler & & -0.67 \\
\hline Speed & 9.33 & -2.67 \\
\hline Efficiency & 80.33 & \\
\hline
\end{tabular}

Source: Walsh; Becker (1996).

Due to the small sample used in calculating coefficients in Table A-1 $(n=4)$, the variability in the estimated values is unknown. The coefficient estimates simulate the negative impact of yield on overall equipment speed (in miles/hour) and efficiency (acres/hour). This relationship is associated with the increased need to service equipment blades and remove machinery clogs (Walsh; Becker 1996). The time per unit of output (hours/dry ton) decreases, along with unit costs, as long as the rate of yield increase exceeds the rate of cost increase. In source documentation for swather speed and efficiency equations, the machine specified was actually a mower. A swather is essentially a combination mower and rake, automatically windrowing cut residues. Thus, the equipment substitution should not substantially affect costs. Any potential residue operation should consider equipment complements, land acreage, and other variables in more detail. 
EFC in acres/hour was calculated for each machine type as a function of machine efficiency and speed from Equation 1, and the variables defined in Equation 2 (Walsh; Becker 1996).

Equation $2 E F C_{i}=\frac{M S_{i} \times M W_{i} \times F E_{i}}{8.25}$

Where:

$$
\begin{aligned}
E F C_{i} & =\text { Effective field capacity of machine } \mathrm{i} \text { (acres / hour) } \\
M S_{i} & =\text { Machine } \mathrm{i} \text { speed (miles } / \text { hour) } \\
M W_{i} & =\text { Operational width of machine } \mathrm{i}(\text { feet) } \\
M S_{i} & =\text { Average field efficiency of machine } \mathrm{i}(\%)
\end{aligned}
$$

Yield (dry tons/acre) was multiplied by the inverse of the EFC (hours/acre) to determine the number of productive machine hours required per dry ton. Scheduled time for each implement was calculated by dividing productive time by field efficiency. Scheduled hours were used in estimates of annual equipment use, since farm operators pay for equipment time whether or not it is actually productive.

Also included in residue price estimates were the opportunity costs of using equipment and expending labor for residue production, i.e. income forgone by producing residues rather than alternative products. Opportunity costs of capital equipment (\$/operating hour) were calculated based on the formula for nonland capital costs given in Equation 3.

\section{Equation 3}

$$
\begin{aligned}
N L_{i} & =r \times \frac{0.5 \times\left(P P_{i} \times S V_{i}\right)}{S H_{i}} \\
N L_{i} & =\text { Nonland capital costs for implement } i(\$ / \text { hour }) \\
r & =\text { Interest rate }(\text { proportion }) \\
P P_{i} & =\text { purchase price for implement } i(\$) \\
S V_{i} & =\text { salvage value for implement } i(\$) \\
S H_{i} & =\text { operating hours for implement } i(\$ / \text { hour })
\end{aligned}
$$

The results of Equation 1 through Equation 3 were combined with estimated managerial costs and 1991 nutrient value estimates. Nutrient value estimates were escalated to 1996 values assuming $3 \%$ inflation (Tyson 1991) using Equation 4. 


\section{Equation 4.}

$$
P=\frac{\left(\sum \frac{\left(T C_{i} \times S H_{i}\right.}{E F C_{i}}\right)}{Q}+\left(\frac{N L_{i}}{E F C_{i} \times Y}\right)+N
$$

Where:

$P=$ Estimated market price (collection cost + opportunity cost) $(\$ /$ dry ton roadside)

$T C_{i}=$ Total equipment cost for implement $i(\$ /$ hour $)$

$N=$ Nutrient value of residues $(\$ /$ dry ton)

$Q=$ Total quantity of residues produced (dry tons)

(Other variables as defined previously)

A detailed example of a cost calculation for corn stover for the State of Arkansas follows on the subsequent page.

\section{Calculation Example}

Values in for machine speed and efficiency (calculated using Equation 1) were used to find the EFC for machinery used to collect corn stover.

Table A-2. Machine speed and efficiency values for corn stover cost calculation in Arkansas

\begin{tabular}{|l|c|c|}
\hline & Swather & Baler \\
\hline Machine speed (mph) & 5.1 & 7.2 \\
\hline Machine efficiency (\%) & 83.0 & 72.0 \\
\hline
\end{tabular}

Calculations from the EFC using values from Table A-2 and Equation 2 are given below:

$$
\begin{aligned}
E F C_{\text {swather }} & =\frac{5.1 \times 12 \times 0.83}{8.25}=6.15 \\
E F C_{\text {baler }} & =\frac{7.2 \times 4 \times 0.72}{8.25}=2.51 \\
E F C_{\text {halewagon }} & =E F C_{\text {baler }}(\text { assumed })
\end{aligned}
$$

The EFC of the balewagon was assumed equal to that of the baler, given that field transport depends on the ability of the baler to bale residues for transport to roadside. 
Opportunity cost calculations (\$/hour of equipment use) using Equation 3 are given below.

$$
\begin{aligned}
N L_{\text {swather }} & =0.06 \times\left(\frac{0.5 \times(19620+1746)}{95}\right)=6.74 \\
N L_{\text {baler }} & =0.06 \times\left(\frac{0.5 \times(17856+1597)}{271}\right)=2.15 \\
N L_{\text {balewagon }} & =0.06 \times\left(\frac{0.5 \times(2723+242)}{271}\right)=0.33
\end{aligned}
$$

Opportunity costs for tractor use were calculated per dry ton by substituting the sum of scheduled hours for the swather, baler, and wagon for $\left(A U_{i} \times E F C_{i}\right)$ in Equation 3.

Using Equation 4 and the values calculated in Equations 1 through Equation 3, an example of the overall cost calculation ( $\$$ dry ton) is given below. The overall cost differs from that in the spreadsheet and table because of a rounding error.

$$
P=\left(\frac{49.91 \times 37200+46.10 \times 92600+27.07 \times 92600+24.59 \times 222300}{747500}\right)+0.34+0.29+0.04+058+5.33=25.44
$$

The first term on the right hand side of the equation is an estimate of total equipment costs per dry ton. The numerator was taken from published equipment costs (Lazarus 1997) and calculated equipment operating hours. The next four terms are the opportunity costs ( $\$ /$ dry ton) calculated from the hourly iigures based on equipment productivity and hourly opportunity costs. The final term is an estimate of nutrient values. 
Table A-3. Corn stover owner-operator crop residue harvesting input costs

\begin{tabular}{|c|c|c|c|c|c|c|c|c|}
\hline & $\begin{array}{l}\text { Operating } \\
\text { width (ft) }\end{array}$ & HP & $\begin{array}{l}\text { Productive } \\
\text { time (h/yr) }\end{array}$ & $\begin{array}{l}\text { Average } \\
\text { speed } \\
\text { (mph) }\end{array}$ & $\begin{array}{c}\text { Scheduled } \\
\text { machine } \\
\text { time (h) }\end{array}$ & $\begin{array}{c}\text { Fuel } \\
\text { rate } \\
\text { (gal/h) }\end{array}$ & $\begin{array}{l}\text { Net cost of } \\
\text { implement }\end{array}$ & $\begin{array}{c}\text { Total } \\
\text { cost (S/h) }\end{array}$ \\
\hline \multicolumn{9}{|l|}{ Operation } \\
\hline $\begin{array}{c}\text { Swath/ } \\
\text { condition }\end{array}$ & & & & & & & & \\
\hline $\begin{array}{l}\text { Swather/ } \\
\text { conditioner }\end{array}$ & 12 & $\mathrm{n} / \mathrm{a}$ & 80 & 5.35 & 95 & 3.2 & $\$ 19,620.00$ & $\$ 49.91^{\mathrm{a}}$ \\
\hline Tractor & $\mathrm{n} / \mathrm{a}$ & 100 & 80 & 5.35 & 95 & & $\$ 37,800.00$ & $\$ 24.59^{b}$ \\
\hline \multicolumn{9}{|l|}{ Bale } \\
\hline $\begin{array}{l}\text { Large round } \\
\text { baler } \\
\text { ( } 1500 \text { lb. bales })\end{array}$ & 4 & $\mathrm{n} / \mathrm{a}$ & 200 & 7.67 & 271 & 3.2 & $\$ 17,856.00$ & $\$ 46.10^{\mathrm{a}}$ \\
\hline Tractor & $\mathrm{NA}$ & 100 & 200 & 7.67 & 271 & & $\$ 37,800.00$ & $\$ 24.59^{b}$ \\
\hline \multicolumn{9}{|l|}{ Move bales } \\
\hline Bale wagon & $\mathrm{n} / \mathrm{a}$ & $\mathrm{n} / \mathrm{a}$ & 200 & 7.67 & 271 & 2.1 & $\$ 2,723.00$ & $\$ 27.07^{\mathrm{a}}$ \\
\hline Tractor & $\mathrm{n} / \mathrm{a}$ & 100 & 200 & 7.67 & 271 & & $\$ 37,800.00$ & $\$ 24.59^{b}$ \\
\hline Total & & & & & & & $\$ 153,599.00$ & $\$ 196.85$ \\
\hline
\end{tabular}

${ }^{a}$ Lazarus (1997)

${ }^{\mathrm{b}}$ Walsh; Becker (1996)

Table A-4. Agricultural residue cost assumptions

\begin{tabular}{|l|r|}
\hline \multicolumn{1}{|c|}{ Other input variables } \\
\hline Labor rate & $\$ 9.00$ \\
\hline Fuel price (\$/gall & $\$ 0.85$ \\
\hline Interest rate & $6.0 \%$ \\
\hline PV of salvage value (calculated) & $8.9 \%$ \\
\hline Equipment lifetime (years) & 12 \\
\hline Salvage value \% of purchase price (nominal) $^{\mathrm{a}}$ & $18.0 \%$ \\
\hline
\end{tabular}

${ }^{\mathrm{a}}$ Walsh; Becker (1996) 
Table A-5. Small grain straw and rice straw owner-operator crop residue harvest budget sheet

\begin{tabular}{|c|c|c|c|c|c|c|c|c|}
\hline & $\begin{array}{l}\text { Operating } \\
\text { width (ft) }\end{array}$ & HP & $\begin{array}{l}\text { Productive } \\
\text { time (h/yr) }\end{array}$ & $\begin{array}{c}\text { Average } \\
\text { speed } \\
\text { (mph) }\end{array}$ & $\begin{array}{c}\text { Scheduled } \\
\text { machine } \\
\text { time (h) }\end{array}$ & $\begin{array}{l}\text { Fuel } \\
\text { rate } \\
\text { (gal/h) }\end{array}$ & $\begin{array}{c}\text { Implement } \\
\text { price }\end{array}$ & $\begin{array}{c}\text { Total } \\
\text { cost } \\
(\mathbf{S} / \mathrm{h})\end{array}$ \\
\hline \multicolumn{9}{|l|}{ Operation } \\
\hline \multicolumn{9}{|l|}{ Swath/condition } \\
\hline Swather/conditioner & 12 & $\mathrm{n} / \mathrm{a}$ & 80 & 5.4 & 145 & $3.2^{\mathrm{a}}$ & $\$ 19,620.00^{\mathrm{a}}$ & $\$ 49.91^{\mathrm{a}}$ \\
\hline Tractor & $\mathrm{n} / \mathrm{a}$ & 100 & 80 & 5.4 & 145 & $4.9^{b}$ & $\$ 37,800.00^{b}$ & $\$ 24.59^{6}$ \\
\hline \multicolumn{9}{|l|}{ Bale } \\
\hline $\begin{array}{l}\text { Large round baler } \\
\text { (1500 lb.bales) }\end{array}$ & 4 & $\mathrm{n} / \mathrm{a}$ & 200 & 7.7 & 364 & $3.2^{\mathrm{a}}$ & $\$ 17,856.00^{\mathrm{a}}$ & $\$ 46.10^{\mathrm{a}}$ \\
\hline Tractor & $\mathrm{n} / \mathrm{a}$ & 100 & 200 & 7.7 & 364 & $4.9^{b}$ & $\$ 37,800.00^{b}$ & $\$ 24.59^{b}$ \\
\hline \multicolumn{9}{|l|}{ Move bales } \\
\hline Bale wagon & $\mathrm{n} / \mathrm{a}$ & $\mathrm{n} / \mathrm{a}$ & 200 & 7.7 & 364 & $2.1^{\mathrm{a}}$ & $\$ 2,723.00^{\mathrm{a}}$ & $\$ 27.07^{\mathrm{a}}$ \\
\hline Tractor & $\mathrm{n} / \mathrm{a}$ & 100 & 200 & 7.7 & 364 & $4.9^{b}$ & $\$ 37,800.00^{b}$ & $\$ 24.59^{6}$ \\
\hline Total & & & - & - & & & $\$ 153,599.00$ & $\$ 196.85$ \\
\hline
\end{tabular}

${ }^{2}$ Lazarus (1997)

${ }^{\mathrm{b}}$ Walsh; Becker (1996) 
Table A-6. Hay-alfalfa straw agricultural chemical, fertilizer, real estate tax, and land value (Interest on land and improvements based on $6 \%$ rate) (\$/acre)

\begin{tabular}{|c|c|c|c|c|c|c|c|c|c|}
\hline State & Fertil & $r$ cost & Chemical & & & ant & Real estate taxes ${ }^{2}$ & Lanc & \\
\hline$\overline{\mathrm{AL}}$ & $\$$ & 22.30 & $\$$ & 20.11 & $\$$ & $|12.87|$ & \begin{tabular}{ll|}
$\$ 1.44 \mid$ \\
\end{tabular} & $\$$ & 1,387 \\
\hline$\overline{\mathrm{AR}}$ & $\$$ & 16.12 & $\$$ & 18.48 & $\$$ & $6.67 \mid$ & \begin{tabular}{ll|} 
& $3.13 \mid$
\end{tabular} & $\$$ & 989 \\
\hline$A Z$ & $\$$ & 2.78 & $\$$ & 1.58 & $\$$ & 1.41 & $\begin{array}{ll} & 6.58 \mid \\
\end{array}$ & $\$$ & 399 \\
\hline$\overline{\mathrm{CA}}$ & $\$$ & 19.37 & $\$$ & 21.30 & $\$$ & $|12.63|$ & $\$ 15.53 \mid$ & $\$$ & 2,404 \\
\hline $\mathrm{CO}$ & $\$$ & 2.78 & $\$$ & 1.58 & $\$$ & $1.41 \mid$ & $\$ 3.42$ & $\$$ & 558 \\
\hline $\mathrm{CT}$ & $\$$ & 18.97 & $\$$ & 12.02 & $\$$ & 18.40 & $\$ 31.35$ & $\$$ & 6,811 \\
\hline$\overline{\mathrm{DE}}$ & $\$$ & 18.97 & $\$$ & 12.02 & $\$$ & $18.40 \mid$ & $\$ \quad 2.37 \mid$ & $\$$ & 2,908 \\
\hline FL & $\$$ & 22.30 & $\$$ & 20.11 & $\$$ & $|12.87|$ & $\$ 14.95$ & $\$$ & 2,306 \\
\hline$\overline{G A}$ & $\$$ & 22.30 & $\$$ & 20.11 & $\$$ & $|12.87|$ & $\begin{array}{ll}5.90 \mid \\
\end{array}$ & $\$$ & 1,358 \\
\hline IA & $\$$ & 24.90 & $\$$ & 19.17 & $\$$ & $\mid 13.85$ & \begin{tabular}{ll|}
12.25 \\
\end{tabular} & $\$$ & 1,442 \\
\hline IID & $\$$ & 2.78 & $\$$ & 1.58 & $\$$ & $|1.41|$ & \begin{tabular}{ll|}
$\$ 3.91 \mid$ \\
\end{tabular} & $\$$ & 905 \\
\hline$\overline{\mathrm{IIL}}$ & $\$$ & 24.90 & $\$$ & 19.17 & $\$$ & $|13.85|$ & $\$ 18.08$ & $\$$ & 2,064 \\
\hline$\overline{\mathrm{IN}}$ & $\$$ & 24.90 & $\$$ & 19.17 & $\$$ & $|13.85|$ & \begin{tabular}{ll|}
$\$ 9.80 \mid$ &
\end{tabular} & $\$$ & 1,801 \\
\hline$\overline{\mathrm{KSS}}$ & $\$$ & 7.98 & $\$$ & 5.34 & $\$$ & $3.73 \mid$ & \begin{tabular}{ll|}
$\$ 2.63 \mid$ \\
\end{tabular} & $\$$ & 553 \\
\hline $\mathrm{KY}$ & $\$$ & 16.28 & $\$$ & 9.30 & $\$$ & $6.47 \mid$ & $\$ 3.521$ & $\$$ & 1,377 \\
\hline$\overline{\mathrm{LA}}$ & $\$$ & 16.12 & $\$$ & 18.48 & $\$$ & $6.67 \mid$ & $\$ 2.711$ & $\$$ & 1,176 \\
\hline$\overline{\mathrm{MA}}$ & $\$$ & 18.97 & $\$$ & 12.02 & $\$$ & $18.40 \mid$ & $\$ 30.25$ & $\$$ & 5,596 \\
\hline $\mathrm{MD}$ & $\$$ & 18.97 & $\$$ & 12.02 & $\$$ & 18.40 & \begin{tabular}{ll|}
$\$ 12.66 \mid$ \\
\end{tabular} & $\$$ & 3,826 \\
\hline $\mathrm{ME}$ & $\$$ & 18.97 & $\$$ & 12.02 & $\$$ & $18.40 \mid$ & $\begin{array}{ll}12.36 \\
\end{array}$ & $\$$ & 1,291 \\
\hline $\mathrm{MI}$ & $\$$ & 18.36 & $\$$ & 14.81 & $\$$ & $14.37 \mid$ & $\$ 19.26$ & $\$$ & 1,470 \\
\hline $\mathrm{MN}$ & $\$$ & 18.36 & $\$$ & 14.81 & $\$$ & $\mid 14.37$ & \begin{tabular}{ll|}
$\$ 8.59$ \\
\end{tabular} & $\$$ & 976 \\
\hline $\mathrm{MO}$ & $\$$ & 24.90 & $\$$ & 19.17 & $\$$ & 13.85 & \begin{tabular}{|l|}
$\$$ \\
\end{tabular} & $\$$ & $\overrightarrow{948}$ \\
\hline MS & $\$$ & 16.12 & $\$$ & 18.48 & $\$$ & \begin{tabular}{ll|}
6.67 \\
\end{tabular} & 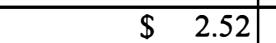 & $\$$ & 917 \\
\hline MT & $\$$ & 2.78 & $\$$ & 1.58 & $\$$ & 1.41 & \begin{tabular}{|l|l|}
$\$$ & 1.62 \\
\end{tabular} & $\$$ & 289 \\
\hline $\mathrm{NC}$ & $\$$ & 16.28 & $\$$ & 9.30 & $\$$ & 6.47 & $\begin{array}{|ll|}\$ & 7.93 \\
\end{array}$ & $\$$ & $\overline{1,970}$ \\
\hline ND & $\$$ & 7.98 & $\$$ & 5.34 & $\$$ & 3.73 & \begin{tabular}{|l|} 
\\
\end{tabular} & $\$$ & 383 \\
\hline $\mathrm{NE}$ & $\$$ & 7.98 & $\$$ & 5.34 & $\$$ & 3.73 & 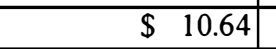 & $\$$ & 632 \\
\hline $\mathrm{NH}$ & $\$$ & 18.97 & $\$$ & 12.02 & $\$$ & 18.40 & \begin{tabular}{ll|}
27.31 \\
\end{tabular} & $\$$ & 2,579 \\
\hline $\mathrm{NJ}$ & $\$$ & 18.97 & $\$$ & 12.02 & $\$$ & 18.40 & \begin{tabular}{ll|}
47.72 \\
\end{tabular} & $\$$ & $\overline{8,173}$ \\
\hline NM & $\$$ & 2.78 & $\$$ & 1.58 & $\$$ & 1.41 & 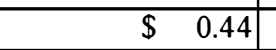 & $\$$ & 258 \\
\hline $\mathrm{NV}$ & $\$$ & \begin{tabular}{|c|}
$2.78 \mid$ \\
\end{tabular} & $\$$ & 1.58 & $\$$ & 1.41 & 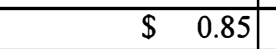 & $\$$ & 332 \\
\hline $\mathrm{NY}$ & $\$$ & $\mid$\begin{tabular}{|l|}
$18.97 \mid$ \\
\end{tabular} & $\$$ & $\begin{array}{l}12.02 \\
\end{array}$ & $\$$ & 18.40 & \begin{tabular}{ll|}
22.22 \\
\end{tabular} & $\$$ & 1,333 \\
\hline $\mathrm{OH}$ & $\$$ & 24.90 & $\$$ & 19.17 & $\$$ & 13.85 & \begin{tabular}{|l|l|} 
& 13.10 \\
\end{tabular} & $\$$ & 1,989 \\
\hline $\mathrm{OK}$ & $\$$ & 5.42 & $\$$ & 3.09 & $\$$ & 2.08 & 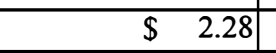 & $\$$ & 547 \\
\hline$\overline{\mathrm{OR}}$ & $\$$ & 19.37 & $\$$ & 21.30 & $\$$ & 12.63 & 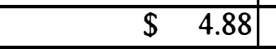 & $\$$ & 928 \\
\hline$\overline{\mathrm{PA}}$ & $\$$ & $18.97 \mid$ & $\$$ & 12.02 & $\$$ & 18.40 & $\$ 20.20$ & $\$$ & 2,505 \\
\hline RI & $\$$ & $18.97 \mid$ & $\$$ & $12.02 \mid$ & $\$$ & 18.40 & $\$ 62.01 \mid$ & $\$$ & 7,206 \\
\hline $\mathrm{SC}$ & $\$$ & 22.30 & $\$$ & 20.11 & $\$$ & 12.87 & $\$ 4.83 \mid$ & $\$$ & 1,363 \\
\hline SD & $\$$ & 7.98 & $\$$ & $5.34 \mid$ & $\$$ & 3.73 & \begin{tabular}{|l|l|}
$\$ 4$ & $4.13 \mid$ \\
\end{tabular} & $\$$ & 319 \\
\hline $\mathrm{TN}$ & $\$$ & 16.28 & $\$$ & $9.30 \mid$ & $\$$ & 6.47 & $\$ \quad 5.08 \mid$ & $\$$ & 1,526 \\
\hline TX & $\$$ & 5.42 & $\$$ & 3.091 & $\$$ & 2.08 & $\$ 3.431$ & $\$$ & 566 \\
\hline UT & $\$$ & 2.78 & $\$$ & $1.58 \mid$ & $\$$ & 1.41 & $\begin{array}{ll}2.00 \mid \\
\end{array}$ & $\$$ & 697 \\
\hline $\mathrm{VA}$ & $\$$ & 16.28 & $\$$ & $9.30 \mid$ & $\$$ & 6.47 & $\$ 8.52$ & $\$$ & $\overline{1,925}$ \\
\hline VT & $\$$ & $18.97 \mid$ & $\$$ & $12.02 \mid$ & $\$$ & 18.40 & $\$ 18.10 \mid$ & $\$$ & 1,533 \\
\hline WA & $\$$ & $19.37 \mid$ & $\$$ & $21.30 \mid$ & $\$$ & 12.63 & $\$ 6.63$ & $\$$ & 1,117 \\
\hline WI & $\$$ & 18.36 & $\$$ & $14.81 \mid$ & $\$$ & 14.37 & $\$ 21.26$ & $\$$ & 1,175 \\
\hline WV & $\$$ & 16.28 & $\$$ & 9.301 & $\$$ & $\begin{array}{l}6.47 \\
\end{array}$ & \begin{tabular}{ll|} 
& 1.63 \\
\end{tabular} & $\$$ & 965 \\
\hline WY & $\$$ & 2.78 & $\$$ & 1.58 & $\$$ & 1.41 & 0.86 & $\$$ & 206 \\
\hline
\end{tabular}

Source: USDA NASS (1997) 
Table A-7. Hay-alfalfa cost assumptions

\begin{tabular}{|c|c|c|}
\hline Other input assumptions & & \\
\hline Labor rate (except for discing/planting) & $\$$ & 9.00 \\
\hline Fuel price (\$/gallon) & $\$$ & 0.85 \\
\hline Interest rate & & $6.0 \%$ \\
\hline \multicolumn{3}{|l|}{ Tractor purchase price } \\
\hline $360 \mathrm{HP}$ & $\$$ & $120,600.00$ \\
\hline $160 \mathrm{HP}$ & $\$$ & $74,400.00$ \\
\hline $100 \mathrm{HP}$ & $\$$ & $37,800.00$ \\
\hline PV of salvage value (calculated) & & $8.9 \%$ \\
\hline Equipment lifetime (years) & & 12 \\
\hline Salvage value $\%$ of purchase price (nominal) & & $18.0 \%$ \\
\hline \multicolumn{3}{|l|}{ Opportunity costs of capital (\$/hour) } \\
\hline Tandem disk & $\$$ & 2.90 \\
\hline Fertilizer spreader & $\$$ & 2.00 \\
\hline Roller harrow & $\$$ & 2.00 \\
\hline Planter & $\$$ & 4.10 \\
\hline Swather & $\$$ & 6.80 \\
\hline Baler & $\$$ & 2.40 \\
\hline Wagon & $\$$ & 0.30 \\
\hline
\end{tabular}

Table A-8. Hay alfalfa owner-operator crop budget sheet

\begin{tabular}{|c|c|c|c|c|c|c|c|c|}
\hline & $\begin{array}{c}\text { Operating } \\
\text { width (ft) }\end{array}$ & $\begin{array}{c}\text { Tractor } \\
\text { power } \\
\text { (HP) }\end{array}$ & $\begin{array}{l}\text { Productive } \\
\text { time (h/yr) }\end{array}$ & $\begin{array}{c}\text { Average } \\
\text { speed } \\
\text { (mph) }\end{array}$ & $\begin{array}{c}\text { Scheduled } \\
\text { machine } \\
\text { time (h) }\end{array}$ & $\begin{array}{r}\text { Fuel rate } \\
(\mathrm{gal} / \mathrm{h})\end{array}$ & $\begin{array}{l}\text { Implement } \\
\text { Price (\$) }\end{array}$ & $\begin{array}{c}\text { Total } \\
\text { cost }(S / h)\end{array}$ \\
\hline \multicolumn{9}{|l|}{ Operation } \\
\hline \multicolumn{9}{|l|}{ Disc } \\
\hline Tandem disk rigid & 15 & 100 & 100 & 5.5 & 120 & $\overline{\mathrm{n} / \mathrm{a}}$ & $\$ 10,838.00$ & $\$ 40.52$ \\
\hline Tractor & $\mathrm{n} / \mathrm{a}$ & $\mathrm{n} / \mathrm{a}$ & 100 & 5.5 & 120 & $\mid 4.9$ & $\$ 37,800.00$ & $\$ 24.59$ \\
\hline \multicolumn{9}{|l|}{ Spread fertilizer } \\
\hline Fertilizer spreader $4 \mathrm{~T}$ & 40 & 100 & 100 & 6.0 & 143 & $\mathrm{n} / \mathrm{a}$ & $\$ 8,636.00$ & $\$ 56.19$ \\
\hline Tractor & $\mathrm{n} / \mathrm{a}$ & $\mathrm{n} / \mathrm{a}$ & 100 & 6.0 & 143 & 4.9 & $\$ 37,800.00$ & $\$ 24.59$ \\
\hline \multicolumn{9}{|l|}{ Roller Harrow } \\
\hline Roller harrow & 12 & 100 & 100 & 6.0 & 132 & $\mathrm{n} / \mathrm{a}$ & $\$ 8,236.00$ & $\$ 32.67$ \\
\hline Tractor & $\mathrm{n} / \mathrm{a}$ & $\mathrm{n} / \mathrm{a}$ & 100 & 6.0 & 132 & 4.9 & $\$ 37.800 .00$ & $\$ 24.59$ \\
\hline \multicolumn{9}{|l|}{ Plant } \\
\hline Broadcast seeder & 15 & 100 & 100 & 5.0 & 133 & $\mathrm{n} / \mathrm{a}$ & $\$ 16,817.00$ & $\$ 52.08$ \\
\hline |Tractor & $\mathrm{n} / \mathrm{a}$ & $\mathrm{n} / \mathrm{a}$ & 100 & 5.0 & 133 & 4.9 & $\$ 37.800 .00$ & $\$ 24.59$ \\
\hline \multicolumn{9}{|l|}{ Swath/condition } \\
\hline Swather/conditioner & 12 & 100 & 80 & 5.6 & 94 & $\mathrm{n} / \mathrm{a}$ & $\$ 19,620.00$ & $\$ 49.91$ \\
\hline Tractor & $\mathrm{n} / \mathrm{a}$ & $\mathrm{n} / \mathrm{a}$ & 801 & 5.6 & 94 & 4.9 & $\$ 37,800.00$ & $\$ 24.59$ \\
\hline \multicolumn{9}{|l|}{ Bale } \\
\hline Large round baler & 4 & 100 & 200 & 8.11 & 265 & $\mathrm{n} / \mathrm{a}$ & $\$ 17,856.00$ & $\$ 46.10$ \\
\hline Tractor & $\mathrm{n} / \mathrm{a}$ & $\mathrm{n} / \mathrm{a}$ & 200 & 8.11 & 265 & 4.9 & $\$ 37.800 .00$ & $\$ 24.59$ \\
\hline \multicolumn{9}{|l|}{ Move bales } \\
\hline Bale wagon & $\mathrm{n} / \mathrm{a}$ & 100 & 200 & 8.1 & 265 & $\mathrm{n} / \mathrm{a}$ & $\$ 2,723.00$ & $\$ 27.07$ \\
\hline Tractor & $\mathrm{n} / \mathrm{a}$ & $\mathrm{n} / \mathrm{a}$ & 200 & 8.11 & 265 & 4.9 & $\$ 37,800.00$ & $\$ \$ 24.59$ \\
\hline Total economic cost/ & & & & & & & & $\$ 476.67$ \\
\hline
\end{tabular}




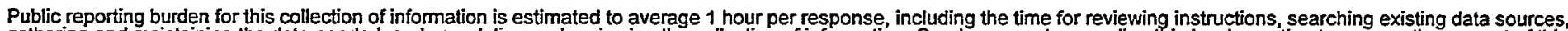

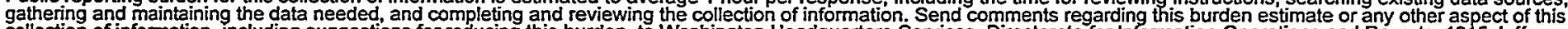

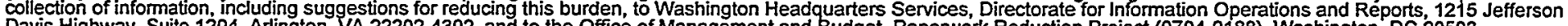
Davis Highway, Suite 1204, Arlington, VA 22202-4302, and to the Office of Management and Budget, Paperwork Reduction Project (0704-0188), Washington, DC 20503.
1. AGENCY USE ONLY (Leave blank)
2. REPORT DATE
3. REPORT TYPE AND DATES COVERED
September 1998
NREL Subcontract Report

4. TITLE AND SUBTITLE

Lignocellulosic Feedstock Resource Assessment

5. FUNDING NUMBERS

Task \#:BF888000

6. AUTHOR(S)

T. Rooney

7. PERFORMING ORGANIZATION NAME(S) AND ADDRESS(ES)

NEOS Corporation

Lakewood, Colorado

9. SPONSORING/MONITORING AGENCY NAME(S) AND ADDRESS(ES)

National Renewable Energy Laboratory

1617 Cole Boulevard

Golden, CO 80401-3393

8. PERFORMING ORGANIZATION

REPORT NUMBER

\section{SUPPLEMENTARY NOTES}

\section{2a. DISTRIBUTION/AVAILABILITY STATEMENT}

National Technical Information Service

U.S. Department of Commerce

5285 Port Royal Road

Springfield, VA 22161

13. ABSTRACT (Maximum 200 words) This report provides overall state and national information on the quantity, availability, and costs of current and potential feedstocks for ethanol production in the United States. It characterizes end uses and physical characteristics of feedstocks, and presents relevant information that affects the economic and technical feasibility of ethanol production from these feedstocks. The data can help researchers focus ethanol conversion research efforts on feedstocks that are compatible with the resource base.

14. SUBJECT TERMS urban tree residue, corn fiber, agricultural crop residues, forest products industry residues, spent brewers grains, recycled primary paper pulp sludge, sugarcane bagasse, wastepaper

12b. DISTRIBUTION CODE

UC-600

0. SPONSORING/MONITORING

AGENCY REPORT NUMBER

NRELSR-580-24189

18. SECURITY CLASSIFICATION OF THIS PAGE
19. SECURITY CLASSIFICATION OF ABSTRACT
15. NUMBER OF PAGES 123

16. PRICE CODE
17. SECURITY CLASSIFICATION OF REPORT

NSN 7540-01-280-5500
Standard Form 298 (Rev. 2-89) Prescribed by ANSI Std. Z39-18 